UNIVERSIDADE DE BRASÍLIA

FACULDADE DE AGRONOMIA E MEDICINA VETERINÁRIA PROGRAMA DE PÓS-GRADUAÇÃO EM AGRONOMIA

RENDIMENTO, COMPONENTES DO ÓLEO ESSENCIAL E PROPAGAÇÃO DE GENÓTIPOS DE MANJERICÕES NO DISTRITO FEDERAL

FABRÍCCIO DHEOCLECIANO PEREIRA DOS SANTOS

DISSERTAÇÃO DE MESTRADO EM AGRONOMIA

BRASÍLIA - DF

FEVEREIRO/2017 


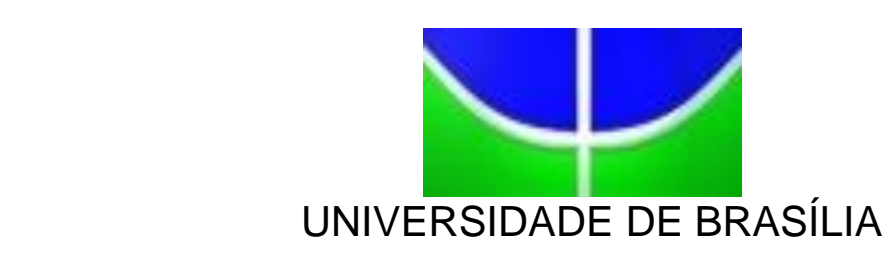

FACULDADE DE AGRONOMIA E MEDICINA VETERINÁRIA

RENDIMENTO, COMPONENTES DO ÓLEO ESSENCIAL E PROPAGAÇÃO DE GENÓTIPOS DE MANJERICÕES NO DISTRITO FEDERAL

FABRÍCCIO DHEOCLECIANO PEREIRA DOS SANTOS

ORIENTADOR: JEAN KLEBER DE ABREU MATTOS CO-ORIENTADOR: ROBERTO FONTES VIEIRA

DISSERTAÇÃO DE MESTRADO EM AGRONOMIA

PUBLICAÇÃO nำ 124/2017

BRASíLIA - DF

FEVEREIRO/2017 
UNIVERSIDADE DE BRASÍLIA

FACULDADE DE AGRONOMIA E MEDICINA VETERINÁRIA

RENDIMENTO, COMPONENTES DO ÓLEO ESSENCIAL E PROPAGAÇÃO DE GENÓTIPOS DE MANJERICÕES NO DISTRITO FEDERAL

Dissertação apresentada à Faculdade de Agronomia e Medicina Veterinária da Universidade de Brasília, como requisito parcial para a obtenção do Grau de Mestre em Agronomia. 
UNIVERSIDADE DE BRASÍLIA

FACULDADE DE AGRONOMIA E MEDICINA VETERINÁRIA

\title{
RENDIMENTO, COMPONENTES DO ÓLEO ESSENCIAL E PROPAGAÇÃO DE GENÓTIPOS DE MANJERICÕES NO DISTRITO FEDERAL
}

\author{
FABRÍCCIO DHEOCLECIANO PEREIRA DOS SANTOS
}

DISSERTAĈ̃O DE MESTRADO SUBMETIDA AO PROGRAMA DE PÓSGRADUAÇẨO EM AGRONOMIA, COMO PARTE DOS REQUISITOS NECESSÁRIOS À OBTENÇÃO DO GRAU DE MESTRE EM AGRONOMIA NA ÁREA DE CONCENTRAÇÃO DE PRODUÇÃO VEGETAL.

Aprovada por:

Eng. Agrônomo Jean Kleber de Abreu Mattos, Doutor (Universidade de Brasília - FAV) (Examinador Interno) CPF: 002.288.181-68. E-mail: kleber@unb.br

Eng. Agrônoma Michelle do Sousa Vilela, Doutora (Universidade de Brasília - FAV) (Examinador Interno) CPF: 919.623.401-63. E-mail: michelle.vilela@unb.br

Eng. Agrônomo Hermes Jannuzzi, Doutor (COOPERORG/DF)

(Examinador Externo) CPF: 066.567.651-49 E-mail: hermes.bsb@gmail.com 


\section{FICHA CATALOGRÁFICA}

Santos, Fabríccio Dheocleciano Pereira dos

Rendimento, Componentes do óleo essencial e propagação de genótipos de manjericões no Distrito Federal / Fabríccio Dheocleciano Pereira dos Santos; Orientação: Jean Kléber de Abreu Mattos Co-orientação: Roberto Fontes Vieira - Brasília, 2017. 87p. Dissertação de mestrado (M) - Universidade de Brasília / Faculdade de Agronomia e Veterinária, 2017.

1.Manjericão. 2.Regressão. 3.Oléo essencial.

\section{REFERÊNCIA BIBLIOGRÁFICA}

SANTOS, F.D.P Rendimento, Componentes do óleo essencial e propagação de genótipos de manjericões no Distrito Federal. Faculdade de Agronomia e Veterinária, Universidade de Brasília-Brasília, 2017; 87p. (Dissertação de mestrado em Agronomia).

\section{CESSÃO DE DIREITOS}

NOME DO AUTOR: Fabríccio Dheocleciano Pereira dos Santos

TíTULO DA DISSERTAÇÃO DE MESTRADO: Rendimento, Componentes do Óleo Essencial e Propagação de Genótipos de Manjericões no Distrito Federal.

GRAU: Mestre. ANO: 2017

É concedida à Universidade de Brasília permissão para reproduzir cópias desta dissertação de mestrado e para emprestar ou vender tais cópias somente para propósitos acadêmicos e científicos. O autor reserva os outros direitos de publicação e nenhuma parte desta dissertação de mestrado pode ser reproduzida sem a autorização por escrito do autor.

Fabríccio Dheocleciano Pereira dos Santos

(61) 9.991489270

E-mail: fabriccio.s@outlook.com 
Aos meus pais e àqueles que acreditaram e acreditam em mim...

Dedico. 


\section{Agradecimentos}

Ao meu pai pelo amor e apoio incondicional e minha família pelo o grande exemplo de vida, consideração, reconhecimento, apoio e incentivo ao estudo.

Ao meu orientador Dr. Jean Kléber de Abreu Mattos, pelo apoio, aprendizado, pelas oportunidades, pela amizade, que muito contribuíram para a conclusão de mais esta etapa.

Ao Co-orientador, Dr. Roberto Vieira pelo apoio, paciência e pelo conhecimento compartilhado. Humberto Biso pelas análises do óleo essencial e Ao Responsável técnico pelo laboratório da Embrapa Cenargen, Ismael, por todo apoio, conhecimento, tempo dedicado e paciência.

A Faculdade de Agronomia e Veterinária e Universidade de Brasília pela oportunidade de realização do trabalho de mestrado.

À amiga e professora Michelle, pela disposição, paciência, alegria e contribuição com seus conhecimentos. 


\section{SUMÁRIO}

RESUMO GERAL

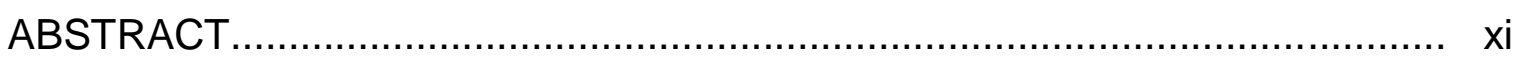

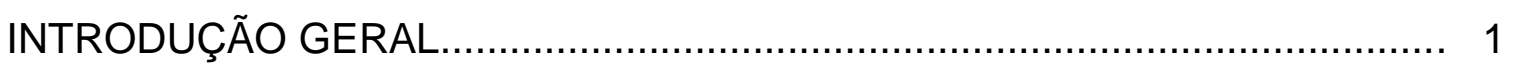

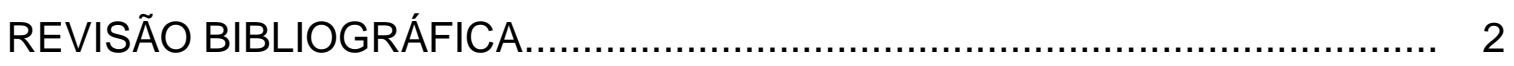

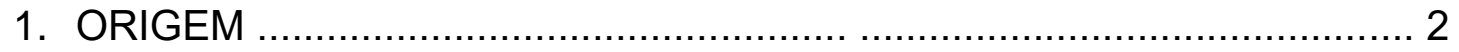

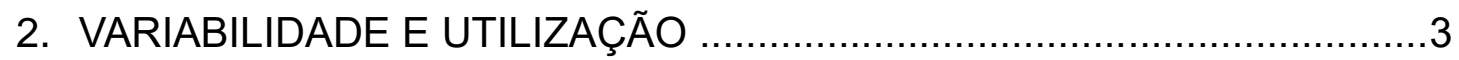

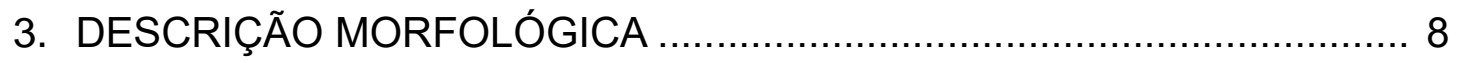

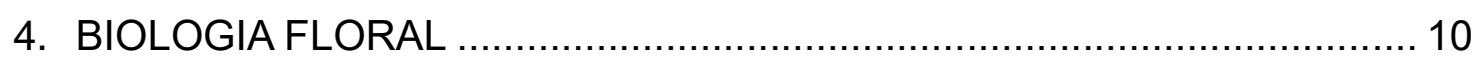

5. ASPECTOS AGRONÔMICOS DO GÊNERO OCIMUM ............................ 13

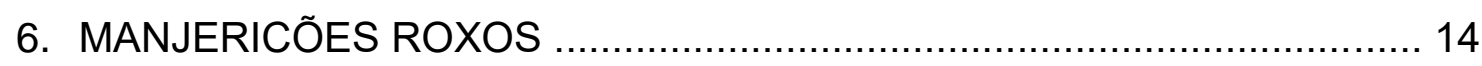

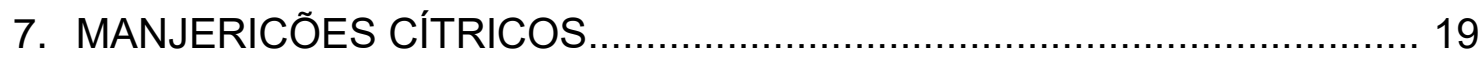

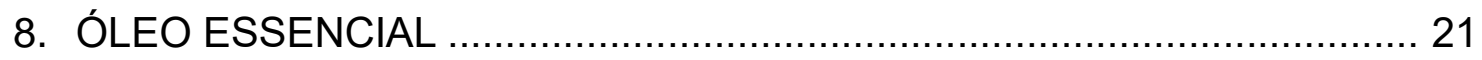

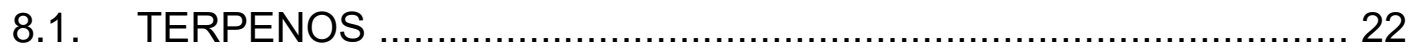

REFERÊNCIAS BIBLIOGRÁFICAS......................................................... 26

CAPÍTULO 1 - EFEIO DE REGRESSÃO À COR VERDE NA PRODUÇÃO DE MUDAS

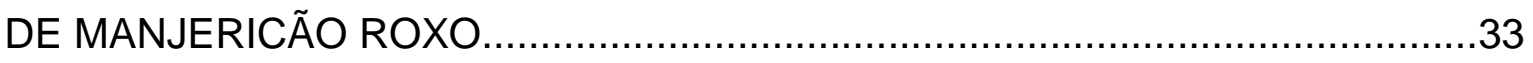

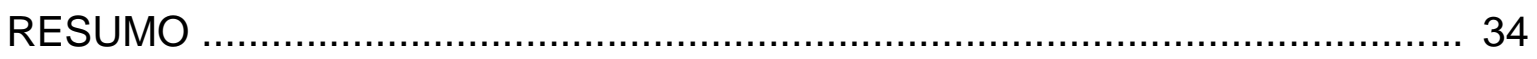

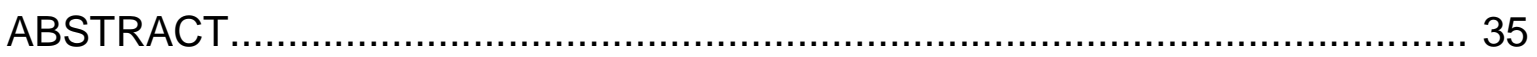

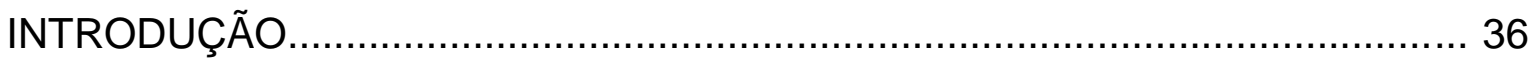

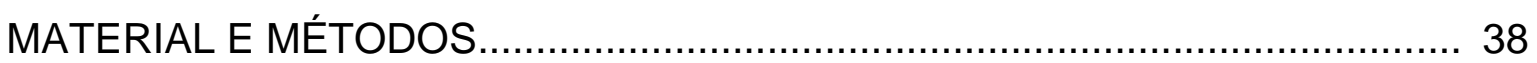

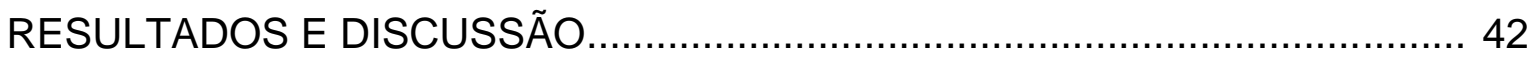

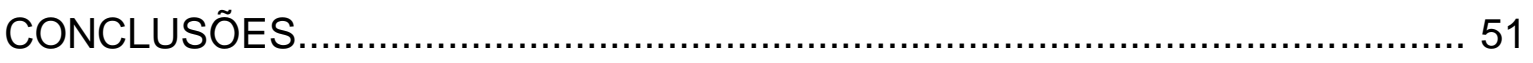

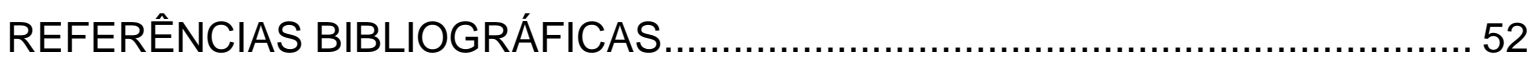

CAPÍTULO 2 - MORFOLOGIA, RENDIMENTO E COMPOSIÇÃO DO ÓLEO ESSENCIAL DE GENÓTIPOS DE MANJERICÕES POPULARES DO DF......... 53

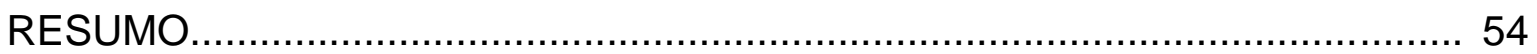

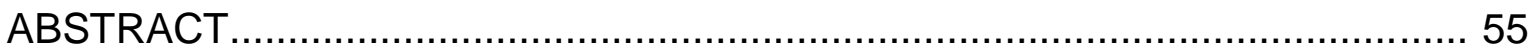

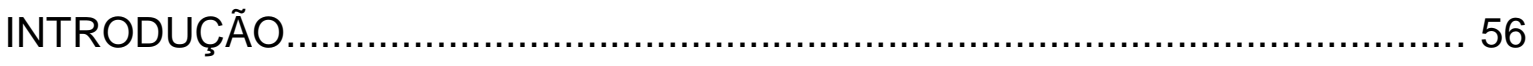

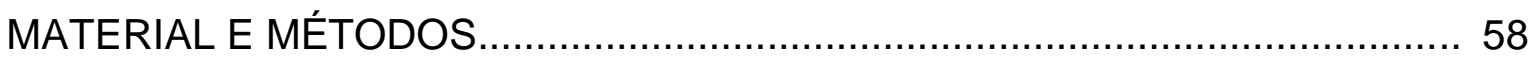

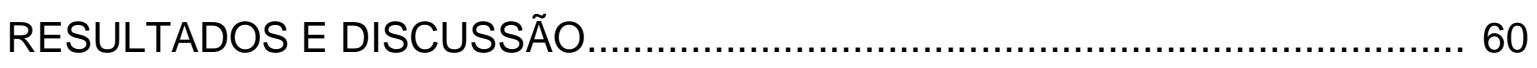

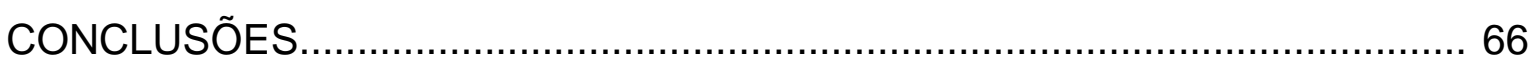

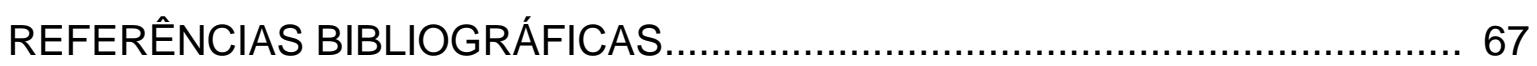




\section{RENDIMENTO, COMPONENTES DO ÓLEO ESSENCIAL E PROPAGAÇÃO DE GENÓTIPOS DE MANJERICÕES NO DISTRITO FEDERAL}

\section{RESUMO GERAL}

O manjericão é uma planta utilizada em diversas áreas, da culinária até a medicina natural. Sua utilização depende de fatores como sua composição química para uso na indústria de cosméticos, medicinal e alimentícia. Também há bastante interesse em sua utilização para fins ornamentais e, para isso, além de características morfológicas diversas, a cor também se tornou um objeto de estudo devido a coloração roxa existente em algumas variedades. A antocianina é uma substancia da classe dos flavonoides, localizada na epiderme vegetal, que confere cor, não só aos manjericões roxos, mas também é responsável pelas cores atrativas em várias espécies de plantas em flores, folhas e frutos, que vão do vermelho ao azul. Porém, a grande instabilidade da coloração roxa no manjericão tem dificultado a exploração comercial dessa variedade. O presente trabalho foi conduzido na Estação Experimental de Biologia, da Universidade de Brasilia, com o objetivo de analisar a expressão da cor roxa em seis genótipos de manjericões roxos, além de avaliar a regressão da coloração roxa para a verde e seus padrões; descrever a morfologia, composição química e rendimento dos óleos essenciais desses seis genótipos de manjericões encontrados no Distrito Federal. Em sementes adquiridas no comércio formal a regressão da coloração roxa tende a ser menor que nas sementes de produção própria, ou aquelas chamadas "de segundo ciclo". As sementes da cultivar Purple Rufles obtidas somente a partir de mudas adquiridas em viveiros, e não de sementes comerciais, apresentaram a mais forte regressão, muito embora tenha diferido estatisticamente apenas do Roxo Feltrin comercial, o acesso de melhor desempenho quanto a regressão. No ensaio de desenvolvimento de mudas regredidas à cor verde versus mudas de coloração roxa observou-se a precocidade e o vigor maior nas mudas regredidas. Ao final do presente ensaio a massa seca das plantas roxas foi, em média, 12,41 g e a das plantas verdes, $17,43 \mathrm{~g}$, estatisticamente diferentes pelo teste $\mathrm{F}$, com $26 \%$ de coeficiente de variação. A análise do óleo essencial mostrou que o teor de óleo essencial nos genótipos de manjericão variou de 0,27 a 0,95\%. O genótipo Local Ornamental de cor roxa, apresentou o segundo maior rendimento de óleo, superior a $0,8 \%$, enquanto que o 
citral, de cor verde, obteve o maior rendimento, de 0,95\%. Os compostos majoritários encontrados no óleo essencial do acesso Purple Ruffles foram metil-chavicol, linalol, alfa trans bergamoteno, 1,8-cineol, alfa cadinol, geranial, neral e eugenol. Os resultados referentes ao rendimento dos oléos essenciais obtidos para cada genótipo foram: Local Hortaliça, 0,7\%; Purple Ruffles, 0,6\%; Citral, 0,5\%, Ruby, 0,4\% e Dark Opal 0,2\%.

Palavras-chave: Ocimum basilicum, óleo essencial, antocianina, características morfológicas, rendimento de óleo. 


\section{YIELD, ESSENTIAL OIL COMPOSITION AND SPREAD OF BASIL GENOTYPES STUDY OF DISTRITO FEDERAL}

\section{ABSTRACT}

The basil is a plant used in diverse areas: as a spice and for natural medicine. Its use depends on factors as its chemical composition for use in medicinal and nourishing cosmetic the industry. Also it has sufficiently interest in its use for ornamental purposes and, for this, beyond diverse morphologic characteristics as the leaf conformation, plant shape and blooms, the color also became an object of study due to some varieties that possess the purple coloration. The anthocyanins are substances of the group of the flavonoids, located in the vegetal epidermis, that confers color, not only the purple basils, but also it is responsible for the attractive colors in some species of plants in flowers, leaves and fruits, that go of the red to the blue one. However, the great instability of the purple coloration has made it difficult the commercial exploration of purple basils. This work was carried out in the Experimental Station of Biology of the University of Brasilia, with the objective to analyze the expression of the purple color in six genotypes of purple basils, to evaluate the regression of the purple coloration for the green and its standards; to describe the morphology, chemical composition and income of essential oils of six genotypes of basils found in Brasilia. In seeds acquired in the formal commerce the regression tends to be lesser that in the seeds of proper production, or those calls "of second cycle". The seeds of cultivating Purple Rufles only gotten from plants acquired in garden centers and not of commercial seeds, had presented the strongest regression, much even so have differed statistical only from the purple commercial Feltrin, the access of better performance. In the assay of development of plants turned green versus purple plants it was observed the precocity and the robustness in the turned green plants. To the end of the present assay the dry mass of the plants (average of the five bigger plants) purple had 12,41 $\mathrm{g}$ average and the green, 17,43 $\mathrm{g}$ average, statistical differents for test $F$, with $26 \%$ of variation coefficient. The results evidence that the genotype Local Hortaliça got the biggest percentage of oil essential income in the assay conditions. The majority composites and the too much composites in bigger amount found in the essential oil of the access Purple Ruffles had been metil-chavicol linalool, bergamoteno alpha trans, 1,8-cineol, geranial was gotten, neral. The referring results to the income of gotten essential oils for each genotype were: Local Hortaliça, $0.7 \%$; Purple 
Ruffles, 0.5\%; Citral, 0.95\%, Ruby, 0.4\% and Dark Opal 0.3\%;

Key words: Ocimum basilicum, essential oil, anthocyanins, morphology, essential oil yield. 


\section{INTRODUÇÃO GERAL}

Em Brasília, no Distrito Federal, a horticultura é uma atividade importante. Uma significativa parte das frutas e praticamente a totalidade das hortaliças são produzidas localmente. A produção de plantas ornamentais também é forte, mesmo que se registre ainda considerável importação de mudas. Entre as plantas ornamentais os manjericões roxos (Ocimum basilicum L.) têm merecido destaque, não apenas pela beleza, mas, sobretudo, pela facilidade de cultivo.

Os manjericões roxos são fascinantes e apresentam um mercado promissor no Brasil. A cor roxa deve-se à produção de antocianinas que se intensifica em presença da luz solar. A procura de mudas de manjericões roxos se dá basicamente por seu apelo ornamental, muito embora a própria antocianina tenha valor de mercado, bem como alguns componentes de seu óleo essencial, como por exemplo o linalol. Alguns manjericões, mesmo que apresentem a cor roxa, são comercializados como hortaliças para produção de molho tipo peso.

No Distrito Federal, sementes das cultivares tipicamente purpúreas, tais como, "Dark Opal", "Rubin" e "Vermelho", são encontradas no comercio. Uma cultivar denominada "Local", de talos e inflorescências roxas e folhas pequenas, é vendida largamente como hortaliça e pode ser encontrada nas feiras e supermercados em geral. Como se trata de uma cultivar que raramente floresce, a obtenção de suas mudas se dá, via de regra, mediante propagação vegetativa. Uma outra cultivar bastante purpúrea com folhas de tamanho médio e denominada simplesmente "Ornamental" é encontrada no mercado de mudas, assim com a cultivar "Purple Rufles". Estas duas últimas, embora somente sejam encontradas na forma de mudas, se cultivadas, produzem sementes.

O potencial dos componentes do elenco de manjericões roxos cultivados em Brasília é motivo de curiosidade, não apenas para seu uso como planta ornamental e hortaliça, mas sobretudo como planta medicinal e aromática.

O objetivo de presente trabalho é descrever a morfologia externa e os componentes do óleo essencial e seu rendimento em cultivares de manjericões roxos encontradas em Brasília. 


\section{REVISÃO BIBLIOGRÁFICA}

\section{ORIGEM}

O gênero Ocimum pertence à família Lamiaceae (Labiatae Juss.). $\mathrm{O}$ cientista Lineu descreveu o gênero Ocimum em 1753, tendo identificado cinco espécies na época. $O$ gênero inclui espécies chamadas coletivamente de manjericões ou alfavacas. Compreende aproximadamente 30 espécies nativas dos trópicos e subtrópicos, que são encontradas na Ásia, África, América Central e América do Sul, sendo valorizadas como fonte de óleos essenciais e aromas compostos. As espécies mais populares em todo o mundo são O. basilicum L., O. africanum Lour. (Syn. Ocimum basilicum citriodorum Vis.), O. americanum L. (sin. O. canum Sims.), O. gratissimum L., O. minimum L., e O. tenuiflorum L. (syn. O. sanctum L.). São importantes economicamente devido a seu uso como aromatizantes e na farmacologia em geral (DARRAH, 1980; SIMON et al.1990; MORALES et al.1993; MORALES E SIMON 1996; PATON et al.1999)

O termo Labiatae, que designa uma família botânica, deriva da forma da corola das espécies, que é labiada. A família encerra cerca de 150 gêneros e 2800 espécies. Mais recentemente, o nome da família vem sendo referido como Lamiaceae, derivado do gênero Lamium. A família Lamiaceae é rica em óleos essenciais e também flavonoides de diferentes estruturas. Esses têm frequentemente provado utilidade para propósitos de taxonomia química (VIEIRA, 2000).

O táxon pode ter tido origem entre a África Ocidental e Central e a migração posterior para outra regiões demográficas foi responsável pela introdução de variações através de cruzamentos naturais e euploidia. (GUPTA, 1994)

\section{Variabilidade e Utilização}

O gênero Ocimum contem ao redor 30 espécies nativas dos trópicos e subtrópicos, com algumas espécies naturalizadas e/ou cultivada em áreas temperadas. A hibridação inter e intraespecífica criou uma confusão significativa na sistemática botânica do gênero Ocimum. A taxonomia do $O$. basilicum é mais complicada pela existência de numerosas variedades, de cultivares e de quimiotipos dentro das espécies, que não diferem significativamente na morfologia. 
Para identificar essa grande variação não só morfológica, mas também química, BLANK et al. (2004) caracterizaram morfológica e agronomicamente acessos de Ocimum sp. visando a seleção de genótipos com alto rendimento de óleo essencial rico em linalol. Observaram grande diversidade entre os genótipos para todas as variáveis morfológicas e agronômicas avaliadas. Houve grande amplitude entre os genótipos quanto ao teor de óleo essencial, variando de 0,202 a 2,536 ml/100g e, para o rendimento de óleo essencial, variando de 1,103 a 21,817 l/ha.

Por causa da grande variabilidade do gênero, diversos autores estabeleceram métodos para a identificação e classificação das plantas, além da morfologia, NURZYÑSKA (2014) caracterizou a variabilidade morfológica, bem como a composição do óleo essencial, de quatro cultivares de manjericão doce que crescem no sudeste da Polônia. Os cultivares apresentaram uma larga diversidade de características morfológicas e químicas. O conteúdo de óleo essencial das plantas testadas variou de $0.91 \%$ a $1.75 \%$ na erva seca ao ar. A composição do óleo essencial foi analisada por meio das técnicas de GC-MS e de GC-FID. Sessenta seis componentes foram encontrados, representando $100 \%$ do óleo essencial. O Linalol era o componente o mais abundante $(29.6 \%-77.5 \%)$, seguido pelo metil-chavicol (0.3\% - 32.5\%), o eugenol (zero a $27.6 \%$ ), (E) - o metil-cinamato (zero a $11.2 \%$ ), o cineol $1.8(1.0 \%-9.4 \%)$, o a-cadinol $(2.8 \%-6.5 \%)$ e o germacreno $D(2.1 \%-4.1 \%)$.

WETZEL et al. (2002) indicam que o gênero Ocimum L. contém diversas espécies que são importantes plantas de valor econômico e medicinal. Os mais importantes são $O$. basilicum L., $O$. americanum L. e seu híbrido $O$. $x$ citriodorum Vis. que são usadas para a produção de óleo essencial e como ervas de vaso. Até agora, os relacionamentos complexos entre estas espécies e sua elevada variabilidade intraespecífica em caracteres morfológicos e bioquímicos não eram bem compreendidos. A diferenciação morfológica destas espécies é muito difícil. Para uma comunicação segura sobre manjericões cultivados é necessária uma extensiva análise de amostras em combinação com marcadores morfológicos, cariotípicos, químicos e moleculares.

As espécies do gênero Ocimum, são extensamente cultivadas como uma fonte do óleo essencial para o uso nos alimentos, nos sabores e nas fragrâncias, e como ervas condimentares e ornamentais. A taxonomia de Ocimum é confusa devido à hibridação interespecífica, à poliploidização, e à existência dos quimiotipos ou raças químicas com morfologia similar. CAROVIC et al. (2007) analisaram vinte e oito 
acessos de manjericão mediante RAPD e AFLP. Os dados separam em ramos de acessos $O$. tenuiflorum e $O$. gratissimum, um conjunto contendo $O$. americanum e acessos de 0 . $\times$ citriodorum, e um conjunto contendo acessos de 0 . basilicum e $O$. minimum, dando uma boa representação dos relacionamentos taxonômicos tradicionais. Dentro do conjunto $O$. basilicum, acessos similares agruparam junto, especificamente O. minimum, O. basilicum "Dark Opal” e O. b. var. difforme. Além dos dados morfológicos, do produto químico e da possibilidade de cruzamento, às análises de RAPD e de AFLP podem ser uma ferramenta útil para resolver problemas existentes na identificação e na classificação dos manjericões.

VIEIRA E SIMON (2006) utilizaram a composição de constituintes do óleo volátil para caracterizar a diversidade entre as espécies mais economicamente importantes de Ocimum. Usando a análise do componente principal nos óleos voláteis aromáticos, os acessos de Ocimum poderiam ser separados em cinco grupos, que não correspondem as diferentes espécies: (1) acessos citral-espatulenol; (2) acessos ricos em linalol; (3) acessos ricos em metilchavicol; (4) acessos linalol-metilchavicol; e (5) acessos ricos em metil(E)-cinamato . O fato que os grupos de espécies de Ocimum estão baseados em características morfológicas não corresponde aos grupos baseados nos constituintes do óleo volátil.

Indicação de mudanças na quantidade de compostos do óleo essencial além de mudanças morfológicas de acordo com o nível e período de desenvolvimento vegetativo foram aferidos por KOUTSOS et al. (2009), ao conduzirem o melhoramento de uma população do "manjericão grego" (Ocimum basilicum L.), selecionando-se plantas com florescimento tardio, forma compacta-esférica e tamanho grande, observaram potencial utilizável para usos ornamental. Após três ciclos da seleção individual aplicando os critérios de seleção acima, o florescimento da população selecionada começou no começo de agosto, em vez de meados de junho da população inicial, e pela porcentagem das plantas com a forma esférica-compacta aumentada de 55 a 90\%. Além disso, variação significativa foi observada no rendimento e na composição do óleo essencial devido à seleção aplicada. $O$ rendimento do óleo em porcentagem aumentou 0.15 para $0.53 \%$. Os constituintes principais do óleo eugenol e linalol aumentaram de 8.60 para 12.90\% (49\%) e de 36.80 a $49.75 \%(34.90 \%)$ respectivamente, enquanto o methyl (E) cinnamate mesmo presente (19.20\%) na população inicial, não foi detectado na população melhorada. 
CAROVIĆ-STANKO et al. (2010) estudaram vinte e oito acessos de manjericão incluindo seis espécies de Ocimum e seis variedades ou cultivares botânicas do $O$. basilicum usando marcadores moleculares, o índice nuclear do DNA, e a contagem do cromossomos. Este é o primeiro estudo que relata o índice nuclear do DNA no gênero Ocimum. Os resultados suportaram a existência de grupos infra genéricos. A secção Ocimum foi dividida mais em dois "grupos" separados. O primeiro grupo conteve os acessos que pertencem à diferentes variedades botânicas e cultivares do $O$. basilicum bem como $O$. minimum, indicando que separar $O$. mínimum como espécie não se justifica. $O$ segundo grupo, compreendendo $O$. americanum, $O$. africanum, e dois acessos de $O$. basilicum var. purpurascens poderia representar um grupo de espécies alopoliploides que compartilham alguns genomas parentais comuns. $O$. tenuiflorum era a espécie mais divergente de acordo com a distância genética; e teve o tamanho menor do genoma, organizado em cromossomos pequenos, e o número mais baixo dos cromossomos. Os dados dos cromossomos obtidos na pesquisa poderiam indicar que o número básico de cromossomos para uma espécie que pertence à secção Ocimum é $\mathrm{x}=12$. Esta sugestão implica que espécies que pertencem ao grupo de $O$. basilicum seriam tetraploides, enquanto espécies que pertencem ao grupo de $O$. americanum seriam hexaploides. Parece que o número básico de cromossomos para $O$. gratissimum poderia ser $\mathrm{x}=10$ e para $O$. tenuiflorum $\mathrm{x}=9$.

CAROVIC-STANKO et al. (2011) indicam que a maioria de cultivares comerciais de manjericão pertencem à espécie Ocimum basilicum L.. Além disso, dentro de $O$. basilicum ocorrem cinco as variedades botânicas principais (var. basilicum L., var. difforme Benth., var. mínimum L., var. purpurascens Benth. e var. thyrsiflorum /L./ Benth.), que são as mais encontradas no mercado. Níveis elevados de variabilidade morfológica e química existem dentro da espécie devido a hibridação intraespecifica e o tempo de cultivo no mundo. Estudaram o poder resolutivo do enfoque morfológico para a identificação de confiança de acessos do manjericão. Seis grupos claramente definidos foram detectados, dando uma boa representação dos relacionamentos taxonômicos tradicionais: manjericões de folhas pequenas (anões); manjericões tipo "Folha de Alface" (Mamute e assemelhados); manjericões verdadeiros ("Genovese" e "Sweet Basil"); manjericões roxos (A) (O.b.var. purpurascens e quatro outros assemelhados); manjericões roxos (B) (Dark Opal e Rubin) e manjericões roxos (C) (Purple Rufles e Moulin Rouge). Para comparar a 
eficiência das características morfológicas na identificação dos acessos, a probabilidade de confusão e o poder discriminador de cada característica foram calculados. Concluíram que com uma análise cuidadosa e uma seleção estrita das características, os marcadores morfológicos fornecem um método barato e de confiança para a seleção rotineira de um grande número acessos, a fim de se monitorar e controlar coleções do germoplasmas.

MOGHADDAM et al. (2011) utilizaram "amplified fragment length polymorphism method" (AFLP) para avaliar a diversidade genética, de 120 acessos de Ocimum que pertencem a cinco espécies e algumas variedades: Ocimum ciliatum, Ocimum minimum, Ocimum basilicum var. purpurascens, $O$. basilicum var. dianatnejadii e O. basilicum var. alba. Oito combinações do primer de AFLP revelaram 150 faixas polimórficas (59.5\%). Os PIC os mais elevados e os mais baixos eram 0.87 e 0.81 para combinações do primer de E-CAA/M-ACC e de E-CAA/M-AGA, respectivamente, com o PIC médio de 0.84 sobre todas as combinações de primer. Os índices de diversidade de Shannon e o índice de diversidade genética de Nei indicaram que Ocimum basilicum teve a variação maior, enquanto Ocimum ciliatum mostrou a menor variação. A identidade genética de Nei medido em cinco espécies de Ocimum e as nas variedades botânicas revelaram a identidade mais elevada (0.939) entre Ocimum minimum e $O$. basilicum var. purpurascens e a identidade genética a mais baixa (0.611) entre $\circ O$. basilicum var. purpurascens e $O$. ciliatum. Em conclusão os resultados do AFLP indicaram que Ocimum minimum deve ser considerado como uma variedade do $O$. basilicum.

DARRAH $(1974,1980)$ classificou a espécie Ocimum basilicum em 7 tipos: altos e esguios (grupo do "sweet basil"); robustos de folhas largas; anão com folhas pequenas ou grandes, compactos também descritos como $O$. basilicum var. thyrsiflora; Púrpuros com tradicional sabor doce; Púrpuros como 'Dark Opal' e um possível híbrido entre $O$. basilicum e $O$. forskolei e $O$. citriodorum entre os quais incluem-se aqueles com aroma de limão descrito por SIMON et al. (1999).

Seis principais variedades botânicas e cultivares de Ocimum basilicum são frequentemente encontrados no mercado mundial (var. basilicum cv. Genovese, var. basilicum cv. Sweet Basil, var. difforme Benth., var. purpurascens Benth., cv. Dark Opal, e var. thyrsiflorum (L.) Benth.). Elas foram colocadas no grupo Basilicum, seção Ocimum (Grupo = O. basilicum), por PUSHPANGADAN (1974). 
O. minimum conhecido como manjericão miúdo, antes considerada uma espécie do gênero Ocimum, é atualmente considerado como uma variedade do $O$. basilicum (VIEIRA et al. 2003).

Ocimum africanum, também referido como Ocimum $x$ citriodorum seria produto de um cruzamento de Ocimum americanum e $O$. basilicum segundo relatado por PATON E PUTIEVSKY (1996). A espécie apresenta-se como do quimiotipo citral.

Experimentos feitos com $O$. basilicum, $O$. canum e $O$. sanctum demonstram que há, além das plantas características de cada espécie, outras que agregam características de duas ou mais espécies (DARRAH, 1980).

TRUTA et al. (2013) estudaram duas variedades do Ocimum basilicum $L$. que apresentaram $2 n=4 x=48$ cromossomos somáticos (var. BR-1) e $2 n=6 x=72$ (var. Folha de Alface), respectivamente. Os cromossomos são pequenos (não ultrapassando $3 \mu \mathrm{m})$, predominantemente do tipo metacêntrico e submetacêntrico. Somente um par de cromossomos com constrições secundárias foi observado nas circunstâncias experimentais.

RYDING (1994), analisando os resultados de experimento de cruzamento entre espécies de Ocimum, concluiu que alguns deles confirmavam a existência de barreiras reprodutivas entre $O$. basilicum e $O$. americanum ( $O$. canum), embora DARRAH (1974) admitisse formas intermediárias entre as duas espécies. DARRAH mencionou o fato de que $O$. forskolei e $O$. basilicum são algumas vezes inférteis. $O$ número de cromossomos sendo o mesmo pelo menos na maioria dos casos. $O$ cultivo conjunto das duas espécies permitiria o fluxo de genes e isso explicaria as dificuldades de distinção dos taxa.

É possível que Ocimum basilicum var. purpurascens seja um híbrido fértil entre O. basilicum e O. forskolei. Seriam necessários cruzamentos experimentais entre $\mathrm{O}$. forskolei e $O$. basilicum var. basilicum para demonstrar a relação entre as duas espécies. Ryding comenta que, aparentemente cultivada há muitos séculos, $O$. basilicum naturalizou-se em muitos lugares, tornando-se, às vezes, difícil estabelecer plantas nativas. Ou são indígenas ou oriundas de antigas introduções. A interfertilidade de Ocimum basilicum com espécies africanas, sugere que a espécie é originária daquele continente. Ela seria originária de O. forskolei e foi sendo modificada pelo cultivo ou por hibridação entre diferentes espécies da Subsecção Ocimum. As principais diferenças entre as duas espécies são: os estames mais curtos 
e o hábito mais ou menos herbáceo, que viriam da hibridação com 0 . kenyense (RYDING, 1994).

Segundo MING et al. (1998), plantas frescas de O. basilicum tem 0,3\% de óleo essencial e flores tem 0,45\%. GRAYER et al. (1996) relataram os vários óleos voláteis de dezesseis acessos de $O$. basilicum e sugeriram que uma classificação intraespecífica desse táxon poderia tomar essas características químicas em consideração. Segundo SIMON (1999), a perfumaria, a farmácia e as indústrias alimentícias utilizam óleos essenciais aromáticos extraídos das folhas e flores do $O$. basilicum, os quais possuem componentes aromáticos como citral, eugenol, linalol, metil-chavicol e metil-cinamato, em concentrações diferentes de acordo com a variedade.

MORALES et al. (1998) instalaram ensaio em casa de vegetação com 41 linhas $\mathrm{S}_{2}$ de Ocimum basilicum (15 roxos, 8 marrons e 18 verdes), para identificar novos e promissores manjericões ornamentais. Variação suficiente foi encontrada dentro dos três genótipos na maioria dos crescimentos, produção e características do óleo essencial. Todas as linhas eram ricas em linalol, no entanto as linhas roxas de inflorescência compacta também continham uma substancial proporção de metil chavicol (20-24\%) e as marrons e brancas continham apenas pequenas quantidades de 1,8-cineol.

\section{Descrição Morfológica}

A interferência do homem com a seleção, cultivo e hibridação no gênero Ocimum, além das várias espécies que o compõem a grande variação morfológica entre elas, contribuem para que algumas características sejam difíceis de serem esclarecidas. Um sistema de descritores padrão, com base nos óleos voláteis, foi proposto, porém, os fatores ambientais são grandes influenciadores na composição destes óleos, o que limita a utilização dos descritores (JANNUZZI, 2013)

Segundo ALBUQUERQUE e ANDRADE (1998): a descrição de Ocimum basilicum L. é a seguinte:

Planta epígea, fanerocotiledonar. Raiz primaria relativamente fina, hialina, com velum e pelos largos, hialinos e finos. Hipocótilo com 0,4-0,6 cm de longitude entre os 3 e os 5 dias, grosso, suculento, de cor verde, com pelos curtos, hialinos e retos. Paracotilédones em número de 2, de 2,2-2,8 a 1,4-2 mm entre os 3 e os 5 dias, longos 
ou ovais, muito largos à medida que se desenvolvem, opostos, subsésseis, membranosos, verdes; ápice obtuso; base auriculada; pecíolo brevíssimo, achatado.

Planta herbácea, anual ou perene, de base lenhosa, aromática, podendo atingir de 30 a $100 \mathrm{~cm}$ de altura. Seus talos são retos ou ascendentes, de seção quadrangular, apresentam ou não pelos (com pelos invertidos concentrados sobre as faces opostas do talo), algumas vezes com pelos nos nós, relativamente mais largos, eretos, dispersos. Ramos robustos ou delgados, abertos ou fechados, sublenhosos ou não, pilosos ou não, eretos ou ascendentes, que terminam algumas vezes na mesma altura. Folhas: 1,4-5,8 x 0,9-3,0 cm, em forma de ovo ou elípticas, inteiras ou sem bordos serreados na metade superior, agudas ou quase agudas, em forma de cunha, com glândulas, sem pelos ou com pelos invertidos sobre as bordas e os nervos inferiores; pecíolos com 0,2-1,5 cm, com canais ou não, relativamente peludos. Inflorescência: 6-30 cm de comprimento, mole, delgada, robusta, ramificada ou não, verticilos separados entre 0,9 e $2 \mathrm{~cm}$; eixo da inflorescência sem cicatrizes negras; brácteas de 7-11 a 3,5-5 mm, persistentes ou não em forma de ovo, de agudas a pontudas, em forma de cunha a afilamento gradativo, peludas (pelos relativamente mais largos nos bordos); pedicelos de 3-5 mm, eretos, achatados, ligeiramente curvados, com pelos curtos e retos. Cálice: $3-5 \mathrm{~mm}$ na antese, ligeiramente reflexo, relativamente peludo na face externa e com velum na interna, com um denso anel de pelos; lábio superior grande, redondo, decurrente cerca da base do tubo; lóbulos laterais deltoides, cuspidados; cálice frutífero de 5-7,5 mm, reflexos, de boca aberta, lábio superior cresce junto. Corola: 5-11 mm, branca, branco-verde ou ligeiramente púrpura; tubo reto, infundibuliforme, mais largo que o cálice, sem pelo; lóbulos do lábio superior, redondos, ligeiramente sinuosos, peludos no dorso; lábio inferior de quase longo a oblongo-elíptico, de bordo com crenas, peludo no dorso. Aparecem fora entre 3 a $7 \mathrm{~mm}$, os posteriores grandes, com apêndices sem pelos ou peludos próximos da base. Ovário sem pelos. Frutos de hasta 1,5-2,5 mm, em forma de ovo, negras; pericarpo reticulado-faveolado (células em reticulo ou em formato de favo), com grande quantidade de mucilagem de aspecto lenhoso.

BLANK et al. (2004) caracterizaram acessos de Ocimum spp. morfologicamente e agronomicamente com o objetivo de obter seleção de genótipos com alto rendimento de óleos essenciais ricos em linalol. Para tanto, analisaram 55 genótipos de um banco de germoplasma de Ocimum. Foi observado que há grande diversidade para variáveis como largura de copa, comprimento de folha, largura de 
folha, relação comprimento/largura de folha e diâmetro do caule de Ocimum sp. Uma observação interessante foi que $52,94 \%$ dos acessos de $\mathrm{O}$. basillicum apresentaram diâmetro do caule superior ou igual a 1,0 cm.

Apesar das diferenças quimiotipicas encontradas durante as fases de crescimento, constatou-se que as diferenças morfológicas são acentuadas, tornando mais fácil ao consumidor, associar alguma característica mais incomum, em que 0 estudo de morfologia permanece sendo importante para o mercado e desenvolvimento de pesquisas com Ocimum. $O$ fato de grande quantidade de acessos não florescer, ajuda a manter a identidade do genótipo em função de se multiplicarem vegetativamente. (JANNUZZI, 2013)

\section{Biologia Floral}

ALMEIDA et al. (2008) estudaram a biologia floral e os mecanismos reprodutivos do alfavacão com vistas ao melhoramento genético. A atividade floral compreendeu três estádios florais: primeiro, pré-antese, quando ocorreu a polinização; segundo, antese, quando aconteceu a abertura assincrônica de estames e, terceiro, pós-antese, quando houve a fecundação dos óvulos. O processo de antese está intimamente relacionado com as condições climáticas. Os acessos de $O$. officinalis (equivalente ao O. basilicum L.) do Banco de Germoplasma de Plantas Medicinais da UESB, apesar de se reproduzirem, predominantemente, por autofecundação, podem apresentar fecundação cruzada, o que evidencia a ampla versatilidade reprodutiva dessa espécie, acentuando a variabilidade genética, a qual é essencial para sua evolução.

PEREIRA NETO E BARROS (2000), em Brasília-DF, utilizaram uma procedência classificada como Ocimum minimum L. para estudos de biologia floral, tendo anotado os seguintes dados: morfologia floral, horário de antese realizando teste de polinização artificial (autopolinização, polinização automática, cruzada e apomixia) e acompanhamento da polinização natural. Foi observada uma floração praticamente durante todo o ano e flores com antese diurna. Não houve produção de frutos. Os visitantes florais foram himenópteros e lepidópteros sendo registradas as seguintes frequências: Apis melifera (170 visitas/minuto) com duração cada de 3 a 12 segundos; Paratrigona lineata (72 visitas/minuto) com duração cada de 10 a 20 s.; 
Lasioglosum com visitas de 8 a 12 segundos; Lepidoptera: sem eficiência como coletor de pólen.

BISPO DOS SANTOS (2008), na tese "Polinização em culturas de manjericão, Ocimum basilicum L. (Lamiaceae), berinjela, Solanum melongena L. (Solanaceae) e tomate Lycopersicon esculentum (Solanaceae) por espécies de abelhas sem ferrão (Hymenoptera, Apidae, Meliponini)", observou que os insetos coletados nas flores de manjericão em canteiro aberto foram Apis mellifera, Paratrigona sp, Trigona sp, Tetragonisca angustula, Nannotrigona testaceicornis, Xylocopa sp, algumas espécies de Lepidoptera, Diptera e Coleoptera. Também verificou que as sementes do tratamento com abelhas apresentaram maior peso e maior porcentagem de germinação do que os outros tratamentos. Concluiu ainda que N. testaceicornis é um agente polinizador de manjericão, podendo ser utilizada em casas de vegetação com o intuito de aumentar o peso das sementes e sua capacidade germinativa.

FACANALI et al. (2009) avaliaram os aspectos da biologia floral (estrutura floral, floração e frutificação) e mecanismos reprodutivos de Ocimum selloi em quatro populações oriundas das regiões de Piquete e Apiaí, Estado de São Paulo, Camanducaia, Estado de Minas Gerais, e Colombo, Estado do Paraná. A viabilidade do pólen foi alta nas quatro populações. A espécie é auto compatível, formando frutos e sementes tanto em polinização livre quanto em autopolinização espontânea, o que mostra uma grande versatilidade reprodutiva da espécie, garantindo a variabilidade genética. A germinação das sementes também foi alta nas quatro populações.

BRITO et al. (2010) estudaram as propriedades do pólen e estigma do manjericão Ocimum basilicum, cv. Maria Bonita, identificando procedimentos simples que possam contribuir para programas de melhoramento. Para análise da disponibilidade, viabilidade do pólen e receptividade de estigma, botões florais foram coletados de hora em hora ao longo do dia, e lâminas eram montadas e coradas, para observação em microscópio óptico. Foi verificado que o manjericão apresenta antese diurna, assincrônica e com a maioria das flores se abrindo entre 10:00 e 11:00 horas. Quanto ao estudo do pólen foi verificado que a viabilidade se manteve elevada ao longo do dia e a conservação por até 90 dias demonstrou bons níveis de viabilidade. O estigma apresentou receptividade desde a pré-antese até a pós-antese. Estas informações são relevantes para os melhoristas que desejam fazer seleção de genótipos ou hibridações em programas de melhoramento, contribuindo para 
aumentar o potencial da espécie que já se destaca como produtora de óleos essenciais.

PUTIEVSKY et al. (1999), em estudos de progênie F1 e F2 de 14, acessos de variedades de Ocimum basilicum verificaram a habilidade de cruzamento entre e dentro destas variedades eram 13 a 19 por cento e a viabilidade era 28 a 50 por cento. A fertilidade do pólen das plantas F1 e F2 estava acima de 70 por cento e as variações na morfologia eram intermediárias entre aquelas indicadas pelos pais. As composições do óleo essencial das plantas F1 e F2 não eram sempre consistentes com as aquelas observadas nas plantas parentais.

CAMPESTRINI E MATTOS (2006), trabalhando em Brasília, em casa de vegetação, com a cultivar mais popular de Ocimum basilicum da região, verificaram que o início do florescimento se deu aos 56 dias da germinação e que a média de altura das plantas foi de $86,42 \mathrm{~cm}$. O tamanho médio da inflorescência foi de 29,57 $\mathrm{cm}$ e o do entrenó da inflorescência foi de $1,67 \mathrm{~cm}$. A área média do limbo foliar foi $5,92 \mathrm{~cm}$. A produção média de número de flores por planta foi 481,28 , e o número médio de inflorescências por planta foi 5,71. A média de flores por inflorescência foi 89,05 , e a taxa média de emissão de flores em pleno florescimento foi de 12,5 flores por semana. A planta mais produtiva emitiu 828 flores e apresentou 10 inflorescências. A planta menos produtiva apresentou 240 flores com apenas quatro inflorescências. $\mathrm{Na}$ progênie resultante da germinação das sementes (média de 1,26 g/planta), 0 surgimento de plantas com manchas de antocianina (3,5\%) evidenciou que houve polinização cruzada natural provavelmente com cultivares de cor púrpura simultaneamente cultivadas na mesma estufa.

Os visitantes florais foram himenópteros e lepidópteros sendo registradas as seguintes frequências: Apis melifera (170 visitas/minuto) com duração cada de 3 a 12 segundos; Paratrigona lineata (72 visitas/minuto) com duração cada de 10 a 20 s.; Lasioglosum com visitas de 8 a 12 segundos; Lepidoptera: sem eficiência como coletor de pólen, segundo estudo anteriormente descrito realizado por PEREIRA NETO E BARROS (2000).

BISPO DOS SANTOS (2008) observou que os insetos coletados nas flores de manjericão em canteiro aberto foram Apis mellifera, Paratrigona sp, Trigona sp, Tetragonisca angustula, Nannotrigona testaceicornis, Xylocopa sp, algumas espécies de Lepidoptera, Diptera e Coleoptera. Também obteve que as sementes do 
tratamento com abelhas apresentaram maior peso e maior porcentagem de germinação do que os outros tratamentos. Concluiu ainda que $N$. testaceicornis é um agente polinizador de manjericão, podendo ser utilizada em casas de vegetação com o intuito de aumentar o peso das sementes e sua capacidade germinativa.

Foi o observado que a menor quantidade de número de flores e maior produção de número de frutos em Ocimum gratissimum sugerem menor capacidade em atrair polinizadores e favorecer a autogamia, aliado a coloração não vistosa da corola. Apesar disso, o estudo sugeriu que o maior visitador floral de Ocimum gratissimum foi Apis mellifera (GONÇALVES, 2006).

\section{Aspectos Agronômicos}

Plantas do Ocimum basilicum var.citriodora foram crescidas em julho e em agosto, sob 9 horas da luz do dia, ao ar livre, além de 0 a 15 horas da luz fluorescente (fc 125), "indoors". A parte aérea das plantas foi colhida quando estavam em flor e foram submetidas a destilação por aparelho Clevenger. O óleo essencial foi analisado por cromatografia de gás e pelo espectrômetro de massa. O desenvolvimento da florada foi o mais rápido quando as plantas foram expostas a 18 horas de luz diariamente. O maior rendimento herbário foi obtido sob 24 horas da luz; para fotoperíodos de 15 a 18 horas o rendimento foi ligeiramente mais baixo, mas as plantas alcançaram o ponto de colheita 10 dias mais cedo. O óleo conteve 19 componentes, 8 de quais foram identificados. A porcentagem de cada um destes componentes foi afetada diferentemente pelos fotoperíodos usados nesta experiência (SKRUBIS E MARKAKIS, 1976)

SPIRIDON (2008), em revisão, focaliza várias espécies de Ocimum, referida frequentemente como "rei das ervas." A botânica de mais de 50 espécies de ervas e arbustos que pertencem a este gênero é relatada completamente, junto com usos e técnicas tradicionais do cultivo. Os Ocimum spp. são uma fonte rica de compostos naturais, os detalhes dos diversos constituintes químicos do óleo essencial, partes das plantas e alimentos derivados e produtos medicinais, tais como monoterpenos, sesquiterpenos, fenilpropanoides, antocianinas, e ácidos fenólicos, assim como seu efeito nas qualidades sensoriais é relatado. Além disso, a ênfase particular é dada à aplicação da biotecnologia para a micro propagação clonal de linhas de Ocimum 
melhoradas e o uso da cultura do tecido de Ocimum para a obtenção de compostos valiosos, tais como antioxidantes fenólicos e componentes do óleo essencial.

\section{Manjericões Roxos}

Os manjericões roxos caracterizam-se pelo elevado conteúdo em antocianinas. As antocianinas são definidas por TIMBERLAKE E BRIDLE (1975) como derivados de sais flavílicos, solúveis em água, os quais são responsáveis pelas cores atrativas de flores, frutos, folhas, sucos de frutas e até mesmo do vinho. Na natureza, encontram-se associadas a moléculas de açúcares. Quando livres destes açúcares são denominadas antocianidinas (agliconas). A estrutura genérica para uma antocianidina natural é apresentada na Figura 1. Dependendo dos substituintes nas posições $R$ e R' define-se uma antocianidina diferente. Uma descrição das principais antocianidinas encontradas na natureza é apresentada na Tabela 1.<smiles>[R]c1cc(-c2[o+]c3cc(O)cc(O)c3cc2O)cc([R])c1O</smiles>

Figura 1. Fórmula estrutural de uma antocianina genérica

Tabela 1. Substituintes R e R' para antocianinas naturais.

\begin{tabular}{lll}
\hline Antocianidina & $\mathbf{R}$ & $\mathbf{R}^{\prime}$ \\
\hline Cianidina & $\mathrm{OH}$ & $\mathrm{H}$ \\
Delfinidina & $\mathrm{OH}$ & $\mathrm{OH}$ \\
Malvidina & $\mathrm{OCH} 3$ & $\mathrm{OCH} 3$ \\
Pelargonidina & $\mathrm{H}$ & $\mathrm{H}$ \\
Peonidina & $\mathrm{OCH} 3$ & $\mathrm{H}$ \\
Petunidina & $\mathrm{OCH} 3$ & $\mathrm{OH}$ \\
\hline
\end{tabular}

Fonte: BEADLE, C. L.. \& CLOSE, D. C.. The Ecophysiology of Foliar Anthocyanin. The Botanical Review 2003. 
PHIPPEN E SIMON (1998) examinaram oito variedades comerciais de manjericão roxo $(O$. basilicum $L$.) como potencial fonte de antocianinas. As variedades de folha larga, "Purple Ruffles", "Rubin" e "Dark Opal" tiveram em média um total de antocianina extraível variando entre 16,63 a $18,78 \mathrm{mg} / 100 \mathrm{~g}$ de tecido fresco, enquanto a variedade ornamental de folhas pequenas, o Manjericão Roxo Miúdo teve apenas $6,49 \mathrm{mg} / 100 \mathrm{~g}$ de tecido fresco. A maior concentração de antocianinas totais deu-se justamente antes do florescimento muito embora oito plântulas tenham acumulado dia a dia todas as 14 antocianinas. Comparações foram feitas com outras fontes de antocianina, resultou demonstrar-se que os manjericões roxos são uma abundante fonte de antocianinas aciladas e glucosiladas e poderiam tornar-se uma especial fonte de pigmentos vermelhos estáveis para a indústria de alimentos.

Os manjericões roxos apresentam a tendência de reverter parcialmente a um fenótipo verde mediante o acúmulo ao acaso de setores foliares verdes durante uma simples estação de crescimento. Segundo PHIPPEN (1999), a biossíntese de pigmentos antociânicos em plantas requer uma interação complexa entre duas categorias de genes: estruturais e regulatórios. Mutações em ambos os tipos de genes não são deletérias, resultando em fenótipos facilmente identificáveis. Uma certa mutação é prevalente em variedades de manjericão roxo (Ocimum basilicum L.) e oferece uma excelente oportunidade para se estudar a regulação de pigmentos antociânicos.

PHIPPEN (1999) investigou a herança e os padrões de estabilidade de características das folhas utilizando a variedade "Purple Ruffles". Com cruzamentos controlados, a herança da expressão de antocianina foi encontrada como sendo governada por dois genes dominantes sendo a crisposidade da margem da folha governada por um único e recessivo gene. Ensaios de intensa luminosidade, análise HPLC e experimentos de adubação, determinaram que a mutação ocorria num gene regulador da rota metabólica da antocianina. Admitiu-se a hipótese de que a introdução do gene $L c$ do milho, poderia estabilizar os pigmentos de antocianinas nas folhas e ajudar a superar a mutação de instabilidade no manjericão. Um protocolo confiável para regeneração e transformação do manjericão foi primeiramente estabelecido e confirmado utilizando o gene gusA. A expressão de antocianina foi detectada em ambos os tecidos transformados e a testemunha regenerou o tecido verde do manjericão, sugerindo que a expressão estável $L c$ poderia não se confirmar. 
SANTOS (2007) em Brasília, mediante polinização entomófila natural facilitada, obteve a ocorrência de formas intermediárias que evidenciaram a polinização cruzada entre as procedências que compartilhavam um campo experimental, confirmando que acessos do gênero Ocimum podem apresentar fecundação cruzada livre, no campo. Houve forte regressão da cor púrpura dos manjericões roxos para a cor verde. $O$ tipo selecionado para o comércio de ornamentais no ensaio, plantas anãs com inflorescência compacta e cor púrpura, ocorreu apenas em 8,33\% das plantas obtidas no terceiro ensaio. $O$ autor catalogou os polinizadores observados na área experimental.

SIMON et al. (1999) assim descrevem as variedades e cultivares de manjericões roxos $(O$. basilicum) pela média de suas medidas e características morfológicas em geral:

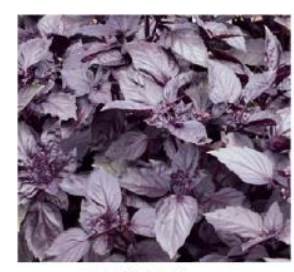

DARK OPAL

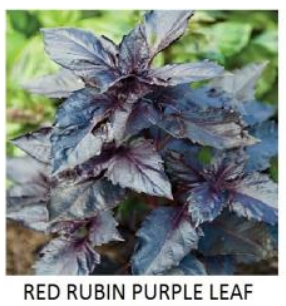

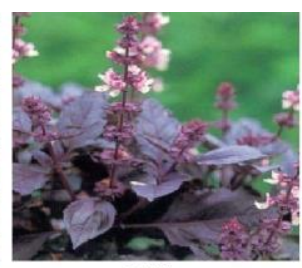

OPAL

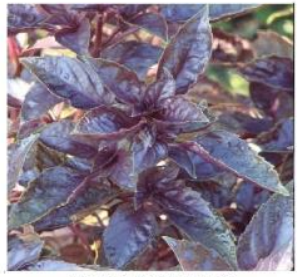

PURPLE RUFFLES

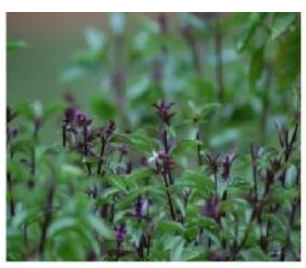

THAI

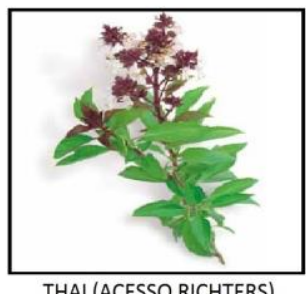

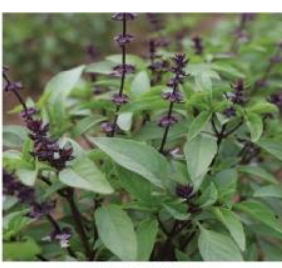

SWEET THAI

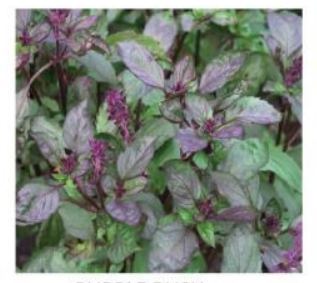

PURPLE BUSH

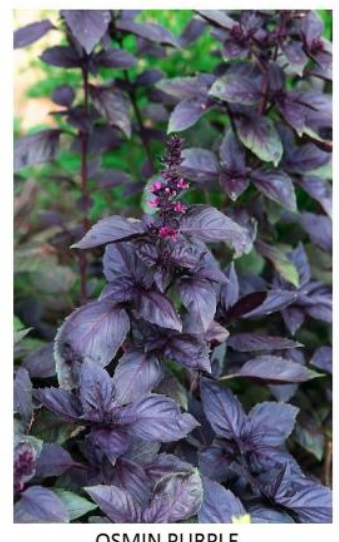

OSMIN PURPLE

Figura 2. Variedades de Manjericões Roxos. Fonte: Imagens.google.com, acesso em fev. 2017.

DARK OPAL: plantas com $43 \mathrm{~cm}$ de altura com diâmetro da parte aérea de 36 $\mathrm{cm}$. Folhas roxas assim como os ramos. Flores róseas e inflorescência roxa. Dias para florescimento, 95. Vigor mediano, plantas medianamente uniformes. Massa fresca da planta 445g, massa seca 74. Rendimento em óleo essencial 1,08\%. Componentes majoritários do óleo essencial (OE), linalol (80\%) e 1,8- cineol (12\%).

OPAL: plantas com $36 \mathrm{~cm}$ de altura com diâmetro da parte aérea de $35 \mathrm{~cm}$. Folhas roxas assim como os ramos. Flores róseas e inflorescência roxa. Dias para florescimento, 99. Vigor mediano, plantas medianamente uniformes. Massa fresca da planta 516g, massa seca 78. Rendimento em óleo essencial 0,91\%. Componentes majoritários do óleo essencial (OE), linalol (80\%) e 1,8-cineol (13\%). 
OSMIN PURPLE: plantas com $40 \mathrm{~cm}$ de altura com diâmetro da parte aérea de $33 \mathrm{~cm}$. Folhas roxas assim como os ramos. Flores róseas e inflorescência roxa. Dias para florescimento, 101. Vigor mediano, plantas desuniformes. Massa fresca da planta 343g, massa seca 53. Rendimento em óleo essencial 0,66\%. Componentes majoritários do óleo essencial (OE), linalol (77\%) e 1,8-cineol (15\%).

OSMIN PURPLE: plantas com $40 \mathrm{~cm}$ de altura com diâmetro da parte aérea de $33 \mathrm{~cm}$. Folhas roxas assim como os ramos. Flores róseas e inflorescência roxa. Dias para florescimento, 101. Vigor mediano, plantas desuniformes. Massa fresca da planta 343g, massa seca 53. Rendimento em óleo essencial 0,66\%. Componentes majoritários do óleo essencial (OE), linalol (77\%) e 1,8-cineol (15\%).

PURPLE BUSH (var. minimum): plantas com $24 \mathrm{~cm}$ de altura com diâmetro da parte aérea de $28 \mathrm{~cm}$. Folhas roxo-esverdeadas, ramos roxos. Flores roxo-claras e inflorescência roxa. Dias para florescimento, 109. Vigor acima da média do grupo, uniformidade baixa. Massa fresca da planta $348 \mathrm{~g}$, massa seca 54 . Rendimento em óleo essencial $1,12 \%$. Componentes majoritários do óleo essencial (OE), linalol (82\%) e 1,8 -cineol (11\%).

PURPLE RUFLES: plantas com $34 \mathrm{~cm}$ de altura com diâmetro da parte aérea de $29 \mathrm{~cm}$. Folhas roxas assim como os ramos. Flores roxo-brilhantes e inflorescência roxa. Dias para florescimento, 134. Vigor acima da média do grupo assim como a uniformidade. Massa fresca da planta $294 \mathrm{~g}$, massa seca 42 . Rendimento em óleo essencial $0,49 \%$. Componentes majoritários do óleo essencial (OE), linalol (55\%) e 1,8-cineol (20\%), metilchavicol (6\%) e metileugenol (9\%).

RED RUBIN PURPLE LEAF: plantas com $42 \mathrm{~cm}$ de altura com diâmetro da parte aérea de $38 \mathrm{~cm}$. Folhas roxas assim como os ramos. Flores róseas e inflorescência roxa. Dias para florescimento, 106. Vigor fraco assim como a uniformidade. Massa fresca da planta 403g, massa seca 63. Rendimento em óleo essencial $0,74 \%$. Componentes majoritários do óleo essencial (OE), linalol $(70 \%)$ e 1,8-cineol (19\%), metilchavicol (10\%) e metileugenol (6\%).

SWEET THAI: plantas com $35 \mathrm{~cm}$ de altura com diâmetro da parte aérea de 44 $\mathrm{cm}$. Folhas verdes como os ramos roxos. Flores róseas e inflorescência roxa. Dias para florescimento, 74. Vigor mediano assim como a uniformidade. Massa fresca da planta $723 \mathrm{~g}$, massa seca 168 . Rendimento em óleo essencial $0,40 \%$. Componentes majoritários do óleo essencial (OE), linalol (6\%) e metilchavicol (60\%). 
THAI (acesso Companion Plants): plantas com $41 \mathrm{~cm}$ de altura com diâmetro da parte aérea de $47 \mathrm{~cm}$. Folhas verdes, talos roxos. Flores róseas e inflorescência roxa. Dias para florescimento, 82. Vigor baixo, uniformidade acima da média do grupo. Massa fresca da planta $536 \mathrm{~g}$, massa seca 111 . Rendimento em óleo essencial $0,75 \%$. Componentes majoritários do óleo essencial (OE), linalol (12\%) e metilchavicol (65\%).

THAI (acesso Richters): plantas com $35 \mathrm{~cm}$ de altura com diâmetro da parte aérea de $36 \mathrm{~cm}$. Folhas verdes, ramos roxo-claros. Flores róseas e inflorescência roxa. Dias para florescimento, 100. Vigor baixo assim como a uniformidade. Massa fresca da planta $443 \mathrm{~g}$, massa seca 86 . Rendimento em óleo essencial $0,52 \%$. Componente majoritário do óleo essencial (OE), metilchavicol (90\%).

CARVALHO (2000), trabalhando em casa de vegetação com $50 \%$ de sombra, encontrou em média $28 \%$ de reversão parcial à cor verde em plantas de manjericão roxo oriundas de sementes adquiridas no comércio formal. As plantas oriundas das sementes de segunda geração apresentaram um índice de regressão $25 \%$ maior. Observou que as plantas roxas apresentaram crescimento mais lento em relação às plantas verdes. Nas plantas roxas a floração e produção de sementes atrasou vintes dias em média em relação às plantas verdes. O serreado da margem do limbo foliar para menos, bem como a estrutura de sua base e a textura também foram alterados acompanhando a perda da cor roxa. Observou que o sombreamento parcial da casa de vegetação interferiu na manutenção da prevalência da cor roxa com o passar do tempo, tendo havido ausência de padrão morfológico específico para a folhas verdes.

SANSON (2009) estudou as características morfológicas e a composição química do óleo essencial de seis acessos de manjericão (Ocimum spp.), dois deles de cor púrpura, codificados como Colunar Roxo (ColR) e Miúdo Roxo (MiuRo), procedentes respectivamente da região de Brasília-DF e de Salvador-BA, classificados como Ocimum basilicum. O primeiro apresentava folhas pequenas ovaladas, com margem serreada, limbo verde escuro com nervuras púrpuras, talo lilás e flores de coloração lilás. O segundo apresentava folhas pequenas ovaladas com margem foliar lisa, limbo foliar de cor verde com nervuras púrpuras, talo lilás e flores de coloração lilás. O quimiotipo de ColR foi Linalol/1,8-cineol e do MiuRo foi metilchavicol.

CANINI (2012) utilizando o mesmo acesso CoIR que SANSON (2009), estudou a sazonalidade dos constituintes químicos, confirmando o quimiotipo linalol/1,8 cineol. Observou que o quimiotipo não mudou da estação chuvosa para a estação seca em 
Brasília-DF, apesar das discretas diferenças na concentração dos componentes de uma estação à outra, destacando-se um aumento da concentração do eugenol na época chuvosa.

\section{Manjericões Cítricos}

SIMON et al. (1999) descrevem dois acessos de Ocimum basilicum tipo "Lemon basil":

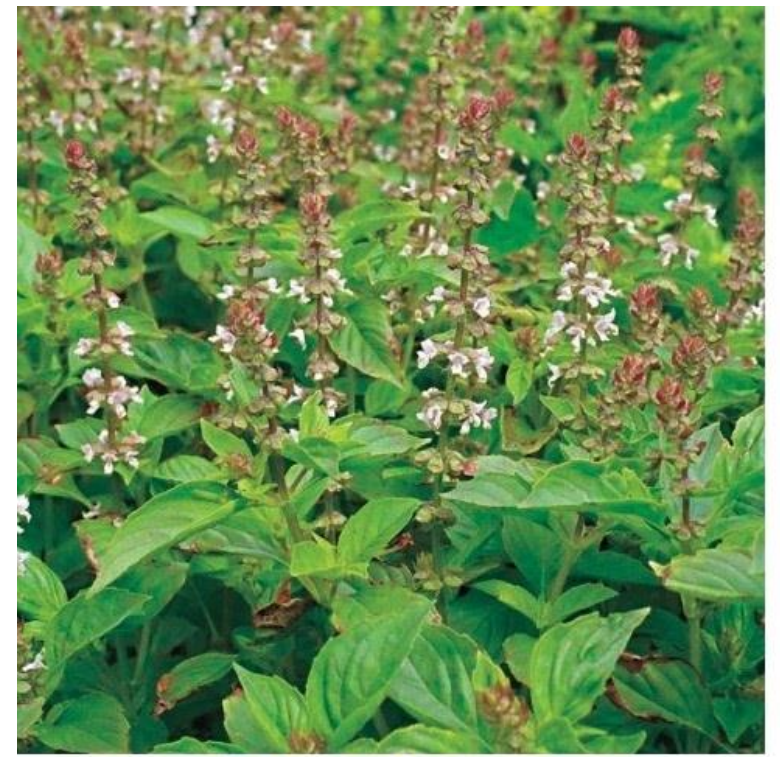

LEMON (CITRIODORUM)

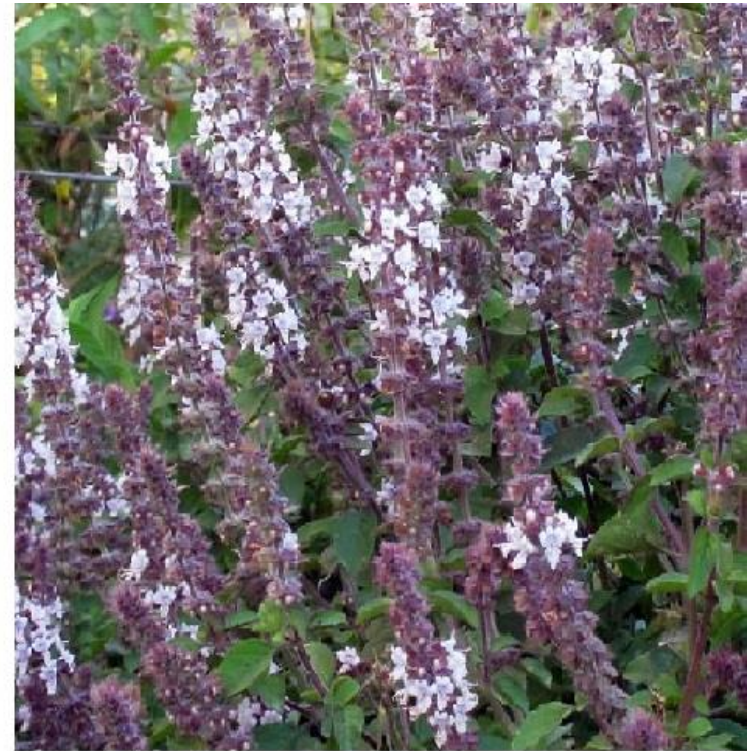

LEMON (CV. Mrs. Burns)

Figura 3. Acessos de Ocimum basilicum tipo "Lemon basil". Fonte: imagens.google.com, fev. 2017.

LEMON ( $x$ citriodorum) - plantas com $33 \mathrm{~cm}$ de altura com diâmetro da parte aérea de $53 \mathrm{~cm}$. Folhas verdes, ramos verdes. Flores brancas e inflorescência verde. Dias para florescimento, 76. Vigor baixo assim como a uniformidade. Massa fresca da planta 432 g, massa seca 118 . Rendimento em óleo essencial $0,27 \%$. Componentes majoritários do óleo essencial (OE), linalol (24\%), citral (19\%).

LEMON (cv. Mrs. Burns): plantas com $52 \mathrm{~cm}$ de altura com diâmetro da parte aérea de $55 \mathrm{~cm}$. Folhas verdes, ramos roxo-claros. Flores róseas e inflorescência roxa. Dias para florescimento, 94. Vigor baixo assim como a uniformidade. Massa fresca da planta $883 \mathrm{~g}$, massa seca 177 . Rendimento em óleo essencial $1,28 \%$. Componentes majoritários do óleo essencial (OE), linalol (61\%), citral (16\%).

Mediante análise meiótica MUKHERJEE et al. (2005) indicaram: $2 n=72$ cromossomos em O. basilicum var. citriodorum. GRAYER et al. (1996) estudando 
vários acessos de Ocimum verificaram que geranial e neral eram os principais componentes do óleo essencial de O. $x$ citriodorum (Ocimum basilicum var. citriodorum).

MORALES E SIMON, (1997) citam as cultivares tipo "Lemon Basil" com um intenso aroma de limão, folhas verde escuras e pequenas flores brancas, oferecendo um novo tipo de manjericão "cítrico" para a indústria de ervas.

ECHIM (1993), menciona uma cultivar do tipo "Lemon basil" que permanece com pequena estatura e compacta, com folhas estreitas e geralmente folhas pequenas e que a recomenda para ornamentação culinária.

HASAGAWA et al. (1997) indicam a variedade "Lemon basil" que tem sido cultivada como erva culinária, usada fresca ou seca em arranjos florais e "poutpourris". A variedade também é utilizada para na medicina, perfumaria, cosmética e como especiaria.

TANSI E NÁCAR (2000) estudaram os componentes do óleo essencial bem como a produtividade de biomassa vegetal e óleo essencial (OE) de um manjericão "cítrico" comercial cultivado na região mediterrânea da Turquia, o qual pode ser colhido três vezes em pleno florescimento. Em tais condições se o semeio for precoce, o número de colheitas sobe para quatro. A biomassa fresca de folhas encontrada foi $2760 \mathrm{~kg} / 100 \mathrm{~m}^{2}$ sendo de $571,52 \mathrm{~kg} / 100 \mathrm{~m}^{2}$ o peso da biomassa fresca. A produção máxima de $\mathrm{OE}(0,71 \%)$ foi obtida na primeira colheita, das flores secas. Os principais componentes do $\mathrm{OE}$ foram Neral e Geranial. A produção máxima desses componentes $(89,28 \%)$ foi obtida na segunda colheita.

SILVA E FERREIRA (2007) estudaram o crescimento e a fenologia de um acesso de Ocimum basilicum var. citriodorum em Brasília, em condições de casa-devegetação, no verão de 2007. Com seis semanas de idade as plantas já estavam em pleno florescimento. A média final da altura das plantas crescidas em vasos de foi 62,7 $\mathrm{cm}$. O coeficiente de variação para altura final foi de apenas $8,77 \%$, indicando uniformidade. A espécie é muito precoce. O florescimento das plantas teve início na quarta semana após o transplante (48 dias da emergência). A biomassa média da parte aérea das plantas foi, respectivamente de $48,1 \mathrm{~g}$. 


\section{8. Óleo Essencial}

Os óleos essenciais são uma mistura complexa de componentes que pode eventualmente aproximar-se de uma centena (CASTRO et al., 2004). Nele podem ser encontrados desde hidrocarbonetos terpênicos, álcoois simples e terpênicos, aldeídos, cetonas, fenóis, ésteres, éteres, óxidos, peróxidos, furanos, ácidos orgânicos, lactonas, cumarinas, até compostos de sulfurados (SIMÕES, et al., 2003).

Observa-se considerável variação na composição química dos óleos essenciais, dependendo dos quimiotipos que são determinados geneticamente e que embora correspondam a vegetais botanicamente idênticos, encontram-se diferenças químicas entre eles. A ocorrência de quimiotipos é comum em plantas ricas em óleos essenciais (RAMOS, 2004).

O genótipo tem marcada influência sobre a composição do óleo essencial bem como o manejo agricultural, época do corte, idade da planta e densidade de plantio, além de fatores ambientais: temperatura, umidade relativa, irradiação e fotoperíodo (BRUNETON, 1991).

Óleo essencial de Ocimum basilicum L., com alta concentração de linalol, é valorizado no mercado internacional e amplamente usado na indústria de condimentos e cosméticos. Para garantir excelente qualidade e rendimento de óleo essencial é crucial a determinação do efeito dos fatores ambientais e de processamento na sua composição. CARVALHO FILHO et al. (2006) avaliaram o efeito do horário de colheita, da temperatura e do tempo de secagem no teor e na composição química do óleo essencial de $O$. basilicum. Colheitas foram realizadas aos 40 e 93 dias após transplante das mudas. Colheitas realizadas às $8: 00 \mathrm{~h}$ e 12:00 $\mathrm{h}$ proporcionaram os maiores rendimentos de óleo essencial. Ao quinto dia de secagem o teor de linalol no óleo essencial subiu de $45,18 \%$ para $86,80 \%$. O basilicum deve ser colhido pela manhã e a biomassa deve ser seca a $40 \stackrel{\circ}{\circ}$ por um período de cinco dias para obter óleo essencial rico em linalol.

Os óleos voláteis apresentam um índice de retenção e são opticamente ativos, sendo que estas propriedades são utilizadas na sua identificação e no controle de qualidade. $\mathrm{Na}$ mistura, esses compostos se apresentam em diferentes concentrações, sendo um deles é o composto majoritário, acompanhado de outros estão em menores concentrações e mais alguns em quantidades ínfimas (RAMOS, 
2004). A qualidade comercial do óleo essencial depende das proporções relativas de seus diferentes constituintes (BRUNETON, 1991).

Numa determinada espécie, a concentração de cada um dos constituintes do seu óleo volátil pode variar durante o desenvolvimento do vegetal. (RAMOS, 2004).

\subsection{Terpenos}

Os terpenos são classificados de acordo com a quantidade de unidades isoprênicas ( 5 carbonos cada), os terpenos com 10 carbonos, embora eles sejam constituidos de duas unidades de isoprenos, são denominados monoterpenos; os de 15 carbonos, sesquiterpenos; 20 carbonos, diterpenos; 30 carbonos, triterpenos; 40 carbonos, tetraterpenos; e mais 40 carbonos, politerpenos (CROTEAU et al., 2000).

Os terpenos originam-se a partir do ácido mevalônico (no citoplasma) ou do piruvato e 3-fosfoglicerato (no cloroplasto). Na rota biossintética do ácido mevalônico, que ocorre no citoplasma das células secretoras dos tricomas peltados, o mevalonato sofre várias reações com moléculas de acetil $\mathrm{CoA}$, podendo formar o pirofosfato de isopentenila (isopentenil-difosfato) e o isômero pirofosfato de dimetil alila (dimetilalildifosfato), que é a unidade básica para a formação dos terpenos, esteróides e carotenóides. Os dois reagem formando o pirofosfato de geranil (isopentenil-difosfato) (TAIZ E ZEIGER, 2004), e a partir dele, por sucessivas reações enzimáticas, são originados linalol e seu éster acetato de linalila, 1,8-cineol, sabineno, hidrato de sabineno e limoneno (CROTEAU et al., 2000; MCCASKILL et al., 1992).

Monoterpenos são predominantemente produtos de origem vegetal e constituinte majoritário dos óleos essenciais, formado por duas unidades de isoprenos, podem ser acíclicos (acetato de linalila, citronelol, geraniol, linalol, nerol, ocimenol), monocíclicos ( $\alpha$-terpineol, 1,8-cineol, limoneno, mentofurano, mentol, piperitenona, pulegona e uroterpineol), bicíclicos ( $\alpha$-pineno, cânfora, tujona, verbenol), ou ainda irregulares (actinidine, liratol, nezukone e tujaplicin) (GOODWIN, 1971; DI STASI, 1996).

Em cada um destes grupos podem ser encontrados compostos não oxigenados ou oxigenados, formando hidrocarbonos térpicos ( $\alpha$ e $\beta$-pineno, limoneno, mirceno), álcoois fenois ( $\alpha$-terpinol e linalol), ester (acetato de linalila) e óxidos (1,8cineol) (BALMÉ, 2004). 
Em O. basilicum, conforme pesquisa realizada em Brasília, os componentes mais comuns no óleo essencial são: 1,8-cineol; linalol, terpinen-4-ol; metilchavicol; eugenol e a-cadinol (SANSON, 2009).

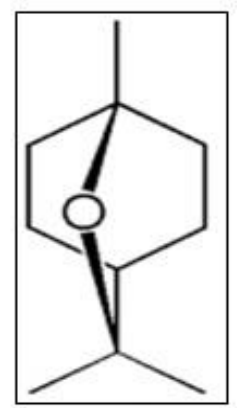

1,8 Cineol

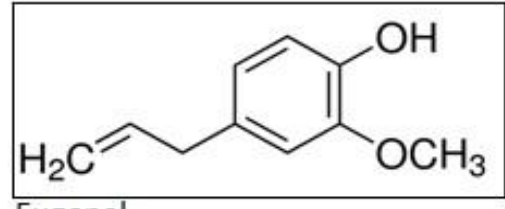

Eugenol
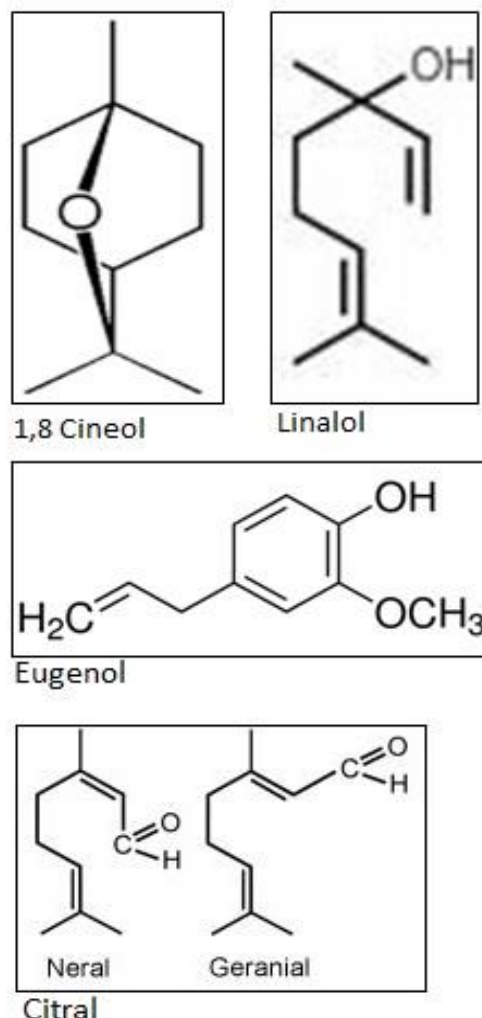

Linalol
Figura 4 Componentes mais comuns encontrados no óleo essencial de manjericão.
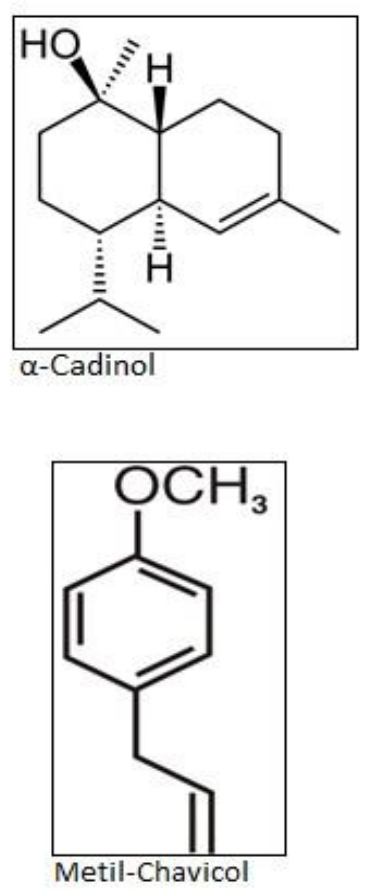

O 1,8-cineol, também conhecido como eucaliptol, é formado a partir do alfaterpineol (MURRAY E LINCOLN, 1970), é um líquido incolor, com odor semelhante à cânfora, praticamente insolúvel em água, miscível em álcool, clorofórmio, éter e óleo fixo (MATOS et al., 2004).

Apresenta algumas aplicações terapêuticas, sendo utilizado no tratamento de reumatismo, tosse e asma brônquica. Apresenta atividade germicida importante na pediculose, bem como atividade relaxante da musculatura lisa do intestino e das vias respiratórias (SANTOS et al., 2005).

O cineol é bastante utilizado para aromatizar ambientes, em loções e preparações farmacêuticas para uso local e interno. Em caso de inalação atua como estimulante expectorante e em uso local atua como anestésico suave e antisséptico. É recomendado em cosméticos para remover manchas da pele, com a vantagem de não promover irritação. Os resultados obtidos com experiências em ratas prenhas via 
oral, indicam que o cineol não é embriofetotóxico até o limite máximo de $1000 \mathrm{mg} / \mathrm{kg}$, que é o nível tóxico para o organismo materno (MATOS et al., 2004).

O 1,8-cineol exalado pelas flores atua como atrativos para polinizadores, incluindo abelhas, mariposas e morcegos. O 1,8-cineol e a cânfora em folhas apresentam efeito repelente para inúmeros herbívoros, como lebres e veados, podendo também apresentar vantagem para várias espécies de Angiospermas em virtude de sua propriedade alelopática, que inibe a germinação de sementes de outras espécies (CROTEAU, et al., 2000). Os níveis de 1,8-cineol dentro da planta são exaltados na medida do aumento da intensidade de luz (OZEL E OZGUVEN,2002).

O linalol é um monoterpeno prevalente nos óleos essenciais em várias espécies de plantas aromáticas. Na rota biossintética dos terpenos, a síntese de linalol é realizada pela enzima linalol sintase, que ocorre anteriormente à do mentol (CROTEAU, et al., 2000). MURRAY E LINCOLN (1970), sugerem que o linalol seja o percursor do alfa-terpineol, limoneno, 1,8-cineol, linalil acetato. No entanto CROTEAU et al. (2000), sugerem que o linalol não seja o percursor do limoneno, mas ambos concordam que ele é formado a partir do pirofosfato de geranil.

O linalol e um importante componente químico aromático largamente utilizado como fixador de fragrâncias na indústria cosmética mundial (GARLET, 2007). Quando emitido pelas flores serve como atrativos para polinizadores, incluindo abelhas, mariposas e morcegos (CROTEAU et al., 2000).

Metil chavicol é um fenilpropeno, um composto orgânico natural. Sua estrutura química consiste no anel benzênico substituído com um grupo methoxy e um grupo propenyl. É um isomero do anetol, diferindo com respeito à posição da ligação dupla. É um líquido incolor, embora as amostras impuras possam parecer amarelas. É um componente de várias árvores e ervas, incluindo o pinheiro, 0 anis, 0 funcho, o estragão, e o manjericão. É usado na preparação de fragrâncias (SILVA, 2009)

O eugenol é um derivado fenilpropanóide, conhecido comumente como essência de cravo, pois o cravo da índia (Eugenia cariophyllata) sua fonte mais conhecida (ESCOBAR, 2002). Possui consistência líquida e oleosa, de cor amarelo claro, com aroma característico, sabor ardente e picante (ALMEIDA, 2004). Os pontos de fusão e ebulição são -9 e + 2530C (BUDAVARI, 1996). Quando em contato prolongado com o ar, apresenta instabilidade, tornando-se mais viscoso e de cor escura avermelhada. Possui várias propriedades farmacológicas, dentre elas 
podemos destacar: antimicrobiana, anti-inflamatória, antioxidante, modulador de respostas imunes, anticarcinogênica, cardiovasculares, antinociceptiva e anestésica local. Podendo-se destacar além disso a atividade espasmolítica, antisséptica, relaxante muscular (ALMEIDA, 2004), e redutora de edema de língua induzido por envenenamento por plantas (DIP et al., 2004).

O a-Cadinol ou 10a-hydroxy-4-cadineno é um composto orgânico, um álcool sesquiterpenoide. É um álcool aromático cuja fórmula é $\mathrm{C}_{15} \mathrm{H}_{26} \mathrm{O}$. É utilizado na criação e/ou manufatura de concentrados de fragrância e sabor de todos os tipos. Apresenta odor de madeira (ASHURST,1999). Sua atividade acaricida foi revelada em recentes resultados de pesquisa que mostram que o $\alpha$-cadinol apresenta forte atividade contra Dermatophagoides pteronyssinos Trouessart e Dermatophagoides farinae (CHANG et al., 2001)

O Citral é formado a partir da composição do geranial (que possui odor forte de limão) com o neral (odor menos intenso de limão). (SIMÕES; SPITZER, 2003). Os representantes de $O$. basilicum que apresentam essa composição são denominadas Lemon (linalol 24\% e citral 19\%) e Lemon Mrs. Burns (Linalol $61 \%$ e citral 16\%) (SIMON et al., 1999) que são variedades hibridas obtidas a partir do cruzamento de O. basilicum $\times$ O citriodorum. O citral é, portanto, é um composto aromático utilizado na perfumaria pelo seu efeito cítrico, usado na indústria alimentícia e para fortalecer o óleo de limão. 


\section{REFERÊNCIAS BIBLIOGRÁFICAS}

ALMEIDA, M.A. Efeitos do eugenol sobre o músculo liso traqueal de cobaia. Fortaleza, 2004. 127p. Dissertação (Mestrado em Ciências Fisiológicas) - Centro de Ciências da Saúde, Universidade Estadual do Ceará.

ALMEIDA, O.S.; SILVA, A.H.B.; SILVA, A.B.; BRITO DA SILVA, A. \& AMARAL, C.L.F. Estudo da biologia floral e mecanismos reprodutivos do alfavacão (Ocimum officinalis L.) visando o melhoramento. Acta Scientiarum. Biological Sciences, v. 26, n. 3, p. 343348, 2008.

ARAUJO, J.M.A. Química de Alimentos: Teoria à prática. Viçosa/MG: Editora UFV, 1999. $416 \mathrm{p}$.

BALMÉ, F. Plantas Medicinais. Brasil: Hemus, 2004. 298 p.

BISPO DOS SANTOS, S. A. Polinização em culturas de manjericão, Ocimum basilicum L. (Lamiaceae), berinjela, Solanum melongena L. (Solanaceae) e tomate Lycopersicon esculentum (Solanaceae) por espécies de abelhas sem ferrão (Hymenoptera, Apidae, Meliponini). Tese de Doutorado, apresentada à Faculdade de Filosofia, Ciências e Letras de Ribeirão Preto/USP Ribeirão Preto, 2008. 62 p.

BLANK, A. F., CARVALHO FILHO, J. D., SANTOS NETO, A. D., ALVES, P. B., ARRIGONI-BLANK, M. D. F., SILVA-MANN, R., \& MENDONÇA, M. D. C. . Caracterização morfológica e agronômica de acessos de manjericão e alfavaca. Horticultura Brasileira, 22(1), 113-116. 2004.

BLANK, A.F.; SOUZA, E.M.; PAULA, J.W.A.; ALVES, P.B. Comportamento fenotípico e genotípico de populações de manjericão. Horticultura Brasileira 28: 305-310. 2010.

BRITO, A.C. SOUZA, J.D. REBOUÇAS, T.N.H.; AMARAL, C.L.F. Propriedades do pólen e do estigma de Ocimum basilicum L. (cultivar Maria Bonita) para aumentar a eficiência de cruzamentos em programas de melhoramento. Revista Brasileira de Plantas Medicinais. 2010;12(2)208-214 Rev. Bras. Pl. Med., Botucatu, v.12, n.2, p.208-214, 2010.

BRUNETON, J. Elementos de Fitoquimica y de Farmacognosia. Zaragoza/ESP: Editorial Acribia, 1991. $594 \mathrm{p}$.

BUDAVARI, S.; O’NEIL, M.G.;SMITH, A. Heckelman, P.;Obenchain, J.The merck index 12a. ed.. Merck \& Co. Inc., Rahway, N.J., 1996.

CANINI, Giselle Beber. Caracterização anatômica e composição química do óleo essencial de manjericão (Ocimum spp.). 2012. xii, 117 f., il. Dissertação (Mestrado em Agronomia) - Universidade de Brasília, Brasília, 2012. 
CAROVIC, K., LIBER, Z., JAVORNIK, B., KOLAK, I. AND SATOVIC, Z. Genetic relationship within Basil (Ocimum) as revealed by RAPD and AFLP markers. Acta Hortic. 760, 171-178. 2007.

CAROVIC-STANKO, K., LIBER, Z., BESENDORFER, V., JAVORNIK, B., BOHANEC, B., KOLAK, I., \& SATOVIC, Z. Genetic relations among basil taxa (Ocimum L.) based on molecular markers, nuclear DNA content, and chromosome number. Plant Systematics and Evolution, 285 (1-2), 13-22. 2010.

CAROVIC-STANKO, K.; ŠALINOVIĆ, A.; GRDIŠA, M.; LIBER, Z.; KOLAK, I.; \& SATOVIC, Z. Efficiency of morphological trait descriptors in discrimination of Ocimum basilicum L. accessions. Plant Biosystems-An International Journal Dealing with all Aspects of Plant Biology, 145(2), 298-305. 2011

CARVALHO FILHO, J. L. S., BLANK, A. F., ALVES, P. B., EHLERT, P. A., MELO, A. S., CAVALCANTI, S. C. \& SILVA-MANN, R. (2006). Influence of the harvesting time, temperature and drying period on basil (Ocimum basilicum L.) essential oil.Revista Brasileira de Farmacognosia, 16(1), 24-30.

CARVALHO, F. H. Variação da pigmentação em seedlings de Ocimum basilicum $L$ var. purpurascens. Universidade de Brasília - Faculdade de Agronomia e Medicina Veterinária. 2002. 28 p. Monografia de Graduação em Agronomia.

CASTRO, H.G.; FERREIRA, F.A.; SILVA, D.J.H. \& MOSQUIM, P.R. Contribuição ao Estudo das Plantas Medicinais. Metabólitos Secundários. 2 ed., Viçosa/MG: Visconde do Rio Branco, 2004. 113 p.

CHANG, S.T.; CHEN, P.F.; WANG, S,Y,; WU, H. H. Antimite activity of essential oils and their constituents from Taiwania cryptomerioides. J Med Entomol. 2001 May;38(3):455-7.

CLOSE, D. C., \& BEADLE, C. L. (2003). The ecophysiology of foliar anthocyanin. The Botanical Review, 69(2), 149-161.

CROTEAU, R.; KUTCHAN, T.M. \& LEWIS, N.G. Natural products (Secondary metabolites). In BUCHANAN, B; GRUISSEM, W. \& JONES, R. Biochemistry \& Molecular Biology of Plants. http://www2.unil.ch//pc/docs/pdf/Met sec.pdf. American Society of Plant Physiologists, 2000.

DARRAH, H. 1974. Investigations of the cultivars of basils (Ocimum). Econ. Bot. 28:6367.

DARRAH, H. 1980. The cultivated basils. Buckeyey Printing Co., Mo. 40 p.

DARRAH, H. Investigations of the cultivars of basils (Ocimum). Econ. Bot. 28:63-67. 1974.

DARRAH, H. The cultivated basils. Thomas Buckeye Printing Co., Mo. 1980. 40 p. 
DI STASI, L.C. Plantas Medicinais: Arte e Ciência. Um guia de estudo inter-disciplinar. São Paulo/SP: Editora UNESP, 1996. 230 p.

DIP, E.C; PEREIRA, N.A; FERNANDES, P.D.C. Ability of eugenol to reduce tongue edema induced by Dieffenbachia picta Schott in mice. Toxic., v. 43, p. 729-735, 2004.

ECHIM, T. 1993.New and Unusual Basil Varieties.Gemuse (München) 29: 239-241.

ESCOBAR, R. G. Eugenol: Propriedades farmacológicas y toxicológicas. Ventajas y desvantajas de su uso. Ver. Cubana Estomatol., v. 39, n.2, p; 139-156, 2002.

FACANALI, R.; CAMPOS, M.M.S.; POCIUS, O.; MING, L.C.; SOARES-SCOTT, M.D.; MARQUES, M.O.M. 'Biologia reprodutiva de populações de Ocimum selloi Benth. Rev. bras. plantas med. [online]. 2009, vol.11, n.2, pp.141-146.

GARLET, T.M.B.; SANTOS, O.S.; MEDEIROS, S.L.P.; MANFRON, P.A.; GARCIA, D.C.; BORCIONI, E.I. \& FLEIG, V. Produção e qualidade do óleo essencial de menta em hidroponia com doses de potássio. v.37, Santa Maria/RS: Ciência Rural, n.4, 2007. p. 956-962.

GONÇALVES, C. B. S. Atividade de insetos nas flores de Ocimum gratissimum L.(Lamiaceae), e suas interações com fatores ambientais. Universidade Federal de Mato Grosso do Sul, Campus de Dourados. Programa de pós-graduação (Mestrado) em Entomologia e Conservação da Biodiversidade. Resumo de Tese de Mestrado 2006. $15 \mathrm{p}$.

GOODWIN, T.W. Aspects of Terpenoid Chemistry and Biochemistry. London and New York/USA: Academic Press, 1971. 440 p.

GRAYER R.J., KITE G.C., GOLSDSTONE F.J., BRYAN-PATON A.; PUTIEVSKY,E. 1996. Infraspecific taxonomy and essential oil chemotypes in sweet basil, Ocimum basilicum. Phytochemistry 4: 1033-1039

GUPTA R. Basil (Ocimum sp) Newsletter - G-15 Gene Banks for medical \& Aromatic Plants. June-December. Vol 5, n.6, pp1-3. 1994.

HASAGAWA, Y., TAJIMA. K., TOI, N., SUGIMURA, Y. 1997. Characteristic components founding the essential oils of Ocimum basilicum L. Flavour Fragr. J., 12: 195- 200.

IZCO, J.; E. BARRENO; M. BRUGUÉS; M. COSTA \& J. DEVESA. 1998. Botánica. McGraw-Hill Interamericana. Madrid, España. 781 pp.

KOUTSOS, T. V.; CHATZOPOULOU, P. S.; \& KATSIOTIS, S. T. Effects of individual selection on agronomical and morphological traits and essential oil of a "Greek basil" population. Euphytica, 170(3), 365-370. 2009. 
MATOS, F.J.A. (ORG); SOUZA, M.P.; MATOS, M.E.O.; MATOS, F.J.A.; MACHADO, M.I.L. \& CRAVEIRO, A.A. Constituintes químicos ativos e propriedades biológicas de plantas medicinais brasileiras. Fortaleza/CE: Editora UFC, 2004. 448 p.

MCCASKILL, D.; GERSHENZON, J. \& CROTEAU, R. Morphology and monoterpene biosynthetic capabilities of secretory cell clusters isolated from glandular trichomes of peppermint (Mentha piperita L.) v.187, Berlin/Heidelberg: Springer, n.4,1992. p. 445454.

MING L. C., SCHEFFER M. C., CORRÊA C. JR., BERGMAN I. I. B. \& ABREU MATOS J.K. Plantas medicinais aromáticas e condimentares - Avanços na pesquisa agropecuária. UEP - Botucatu. 1998. 2v.

MOGHADDAM, M.; OMIDBIAGI, R.; \& NAGHAVI, M. R. (2011). Evaluation of genetic diversity among Iranian accessions of Ocimum spp. using AFLP markers. Biochemical Systematics and Ecology, 39(4), 619-6

MORALES M.R., CHARLES D.J., SIMON J.E. New aromatic lemon basil germplasm. In: JANICK J, SIMON JE (eds) New crops. Wiley, New York, pp 632-635.1993

MORALES M.R., SIMON J.E. New basil selections with compacts inflorescence for the ornamental market. In: Janick J ed) Progress in new crops. ASHS, Alexandria, pp 543546. 1996

MORALES, M.R. \& SIMON, J.E. 'Sweet Dani': a new culinary and ornamental lemon basil. HortScience, v.32, n.1, p.148-149, 1997.

MUKHERJEE, M. ANIMESH K. DATTA, A. K. \& GOUR GOPAL MAITI, G.G. Chromosome Number Variation in Ocimum basilicum L. CYTOLOGIA Vol. 70 (2005), No. 4 455-458

MURRAY, M.J. \& LINCOLN, D.E. The Genetic basis of acyclic oil constituints in Mentha citrate Ehrh. Michigan: Genetics, n.65, 1970. p. 457-471.

NURZYÑSKA-WIERDAK, R. Morphological Variability and Essential Oil Composition of four Ocimum basilicum L. cultivars. Journal of essential oil-bearing plants JEOP 17(1):112-119 - March 2014.

OZEL, A., \& OZGUVEN, M. Effect of different planting times on essential oil components of different min (Mentha spp.) varieties. Tubitak: Turk Agric, 2002. 289294 p.

PATON A, PUTIEVSKY E Taxonomic problems and cytotaxonomic relationships between and within varieties of Ocimum basilicum and related species (Labiatae). Kew Bull 51:509-524.1996.

PATON A., HARLEY M.R., HARLEY M.M. Ocimum: An overview of classification and relationships. In: Histone R, Holm Y (eds.) Basil: The Genus Ocimum. Harwood Academic Publishers, Amsterdam. pp 1-38. 1999 
PEREIRA NETO, J. V. \& BARROS, M. A. G. Biologia reprodutiva e polinização de Ocimum minimum L. (Labiatae). Anais do $51^{\circ}$ Congresso Nacional de Botânica: p. 187. Brasília-DF, 23 a 29/7/2000.

PHIPPEN WB and SIMON JE. Anthocianin Inheritance and Instability in Purple Basil. The Journal of Heredity 2000: 91 (4).

PUTIEVSKY, E.; PATON, A., LEWINSOHN, E.; RAVID, U.; HAIMOVICH, D.; KATZIR, I.; SAADI, D.; DUDAI, N. Crossability and relationship between morphological and chemical varieties of Ocimum basilicum L. J Herbs Species Med Plants 6:11-24.1999.

RAMOS, F. Extração de Óleos Essenciais. Penso logo sou http://pensologosou.no.sapo.pt/etnobotanica/oleosessenciais.htm Phallic Mushroom Creations, 2004. acessado em 2015.

RYDING, O. Notes on the Sweet Basil and its Wild Relatives (Lamiaceae). Economic Botany 48 (1) pp. $65-67.1994$.

SANSON, A. D. Morfologia, produção de biomassa e caracterização química do óleo essencial de seis acessos de ocimum spp. comercializado em Salvador, BA e Brasília, DF. 2009. x, 36 f., il. Dissertação (Mestrado em Ciências Agrárias) Universidade de Brasília, Brasília, 2009.

SANTOS, T. S. \& SANTOS V. X. Atualização de uma coleção de trabalho de acessos do gênero Ocimum. Universidade de Brasília. Faculdade de Agronomia e Medicina Veterinária, Monografia de Graduação em Enga. Agronômica. 2014. 26 p.

SANTOS, E. F. Seleção de tipos de Ocimum basilicum L. de cor púrpura para o mercado de plantas ornamentais. 2007. 58 f. Dissertação (Mestrado em Agronomia) Universidade de Brasília, Brasília, 2007.

SANTOS, M.V.; COSTA, A.M.G.; FROTA, P.T.T.; SOUZA, L.N.C.; BRITO, T.S.; CARDOSO, J.H.L. \& MAGALHÃES, P.J.C. Efeito Vasorelaxante do 1,8-Cineol em Aorta de Rato in vitro. Fortaleza/CE: Anais da 57ํㅗ Reunião Anual da SBPC, 2005.

SILVA, A.K.S. Estudo das alterações eletrofisiológicas produzidas pelo estragol sobre os axônios do nervo ciático e os neurossomas do gânglio da raiz dorsal de ratos.Universidade Estadual do Ceará, Centro de Ciências da Saúde.Fortaleza, 2009. 69p. ; il. Dissertação de Mestrado Acadêmico em Ciências Fisiológicas.

SILVA, C.I.; ALEIXO, K.P.; NUNES-SILVA, B.N.; FREITAS, B.M.; IMPERATRIZFONSECA,V.L. Guia ilustrado de abelhas polinizadoras do Brasil / São Paulo : Instituto de Estudos Avançados da USP / Ministério do Meio Ambiente, 201450 p. ILUSTRAÇÕES. 
SILVA, J. P. L. \& FERREIRA, M. B. F. CURVA DE CRESCIMENTO E PRODUÇÃO DE BIOMASSA DE DOIS ACESSOS DE Ocimum basilicum. Universidade de Brasília. Monografia de Graduação do Curso de Engenharia Agronômica. 2007.20 p.

SIMÕES, C.M.O.; SCHENKEL, E.P.; GOSMANN, G.; MELLO, J.C.P.; MENTZ, L.A. \& PETROVICK, P.R. Farmacognosia: da planta ao medicamento. Porto Alegre/RS: Revista. Ampl, Editora da UFRGS, 2003. 1102 p.

SIMÕES, C.M.; SPITZER, V. Óleos voláteis in: Simões, C.M.O. (Coord.). Farmacognosia da planta ao medicamento; 5 ed. Porto Alegre/Florianópolis UFRGS/UFSC, 2003, p.467-495.

SIMON, J. E., MORALES, M. R., PHIPPEN, W. B., VIEIRA, R. F., \& HAO, Z. (1999). Basil: a source of aroma compounds and a popular culinary and ornamental herb. Perspectives on new crops and new uses, In: JANICK, J. (ed.) Perspectives on new crops and new uses. ASHS Press: Alexandria, p. 499-505.

SKRUBIS, B.; MARKAKIS, P.. The effect of photoperiodism on the growth and the essential oil of Ocimum basilicum (Sweet Basil). Economic Botany, v. 30, n. 4, p. 389393, 1976.

SPIRIDON, O.M. K. Ocimum sp. (Basil): Botany, Cultivation, Pharmaceutical Properties, and Biotechnology Journal of Herbs, Spices \& Medicinal Plants, Volume 13, n.3- Page 123-150 2008.

TAIZ, L. \& ZEIGER, E. Plant Physiology. 3.ed. Massachusetts/USA: Sinauer Associates, 2004. 792 p.

TANSI, S. \& NACAR, S. First cultivation Trials of Lemon Basil (Ocimum basilicum var. citriodorum) in Turkey. Pakistan Journal of Biological Sciences 3 (3): 395-397. 2000.

TIMBERLAKE, C.F., BRIDLE, P. -in- The Flavonoids. Part 1, The anthocyanins, eds. Harborne J.B., Mabry T.J., Mabry H. (Academic Press, N.Y), pp 214-266. 1975.

VAN DEN DOOL, H.; KRATZ, P. Dec. A generalization of the retention index system including linear temperature programmed gas-liquid partition chromatography. Journal of Chromatography, v. 11, p. 463-471, 1963.

VIEIRA, R. F., GRAYER R. J., PATON, A. \& J. E. SIMON - Genetic bioversity of Ocimum gratissimum $\mathrm{L}$. based on volatile oil constituents, flavonoides and RAPD markers. Biochemical Systematics and Ecology. 29: 207-216. 2000.

VIEIRA, R.F.; GOLDSBROUGH, P. \& SIMON, J.E. Genetic Diversity of Basil (Ocimum spp.) Based on RAPD Markers. Journal of the American Society for Horticultural Science 128: 94-99. 2003.

VIEIRA, R.F.; SIMON, J.E. Chemical characterization of basil (Ocimum spp.) based on volatile oils. Flavour and Fragrance Journal. Volume 21, n. 2, p. 214-221 2006. 
WETZEL,S.B. , KRÜGER, H. , HAMMER, K. \& BACHMANN, K. Investigations on Morphological, Biochemical and Molecular Variability of Ocimum L. Species. Volume 9, - Issue 2-3 Page 183-187. 2002. 
Capítulo 1

EFEIO DE REGRESSÃO À COR VERDE NA PRODUÇÃO DE MUDAS DE MANJERICÃO ROXO 


\section{EFEIO DE REGRESSÃO À COR VERDE NA PRODUÇÃO DE MUDAS DE MANJERICÃO ROXO}

\section{RESUMO}

A maior dificuldade para o mercado de mudas de manjericões roxos é a instabilidade da coloração púrpura, uma vez que o produto se destina ao mercado de plantas ornamentais e como fonte de antocianina para a indústria de alimentos e corantes. Além da reversão à cor verde, de origem genética, têm sido relatadas também mudanças nas características morfológicas da planta, tais como, alteração do serreado das folhas, a textura e a estrutura da base do limbo foliar, a diminuição na velocidade do crescimento da planta, e a alteração da cor de acordo com a intensidade luminosa do ambiente. Foram realizados dois ensaios sobre o tema, em condições de casa de vegetação. Sementes e mudas de seis acessos de Ocimum basilicum de cor roxa adquiridas no comércio formal (Dark Opal, Rubi e Roxo) e outras reproduzidas localmente (Purple Rufles, Local Ornamental e Local Hortaliça), foram cultivadas em casa de vegetação na Estação Experimental de Biologia da Universidade de Brasília, onde determinou-se o grau de regressão dos acessos de manjericão roxo à cor verde. As contagens foram expressas em percentagens e transformadas em arcsen\%^0,5 para análise da variância e separação das médias pelo teste de Tukey. No segundo ensaio, para um dos acessos (Purple Rufles), mudas de cada padrão (verde e roxo), após individualizadas em vasos, tiveram seu desenvolvimento acompanhado e analisado para se determinar a influência da regressão para a cor verde em algumas características agronômicas. Concluiu-se que a regressão à cor verde é maior no segundo ciclo de cada semeadura. No acesso Local Hortaliça não houve regressão à cor verde. Houve diferença de vigor entre plantas regredidas à cor verde e não regredidas no acesso Purple Ruffles, sendo as plantas regredidas mais vigorosas. Há um padrão definido ou regular de regressão a cor verde apenas na cultivar Local Ornamental, sempre acompanhando as nervuras do limbo foliar, ao contrário dos demais acessos. A capacidade de florescimento e produção de sementes foi menor no acesso Local Hortaliça. A propagação vegetativa segue sendo a recomendação clássica para se contornar a regressão à cor verde nas cultivares de manjericão roxo.

Palavras-chave: Ocimum basilicum, manjericão roxo, antocianina, instabilidade. 


\section{REVERSAL FOR GREEN COLOR IN PURPLE BASIL SEEDLINGS DEVELOPMENT}

\section{ABSTRACT}

The biggest difficulty for the market of seeds of purple basils is the instability of the purple coloration. The product is destinated to the market of ornamental plants and as source of anthocyanin for the food industry and pigments. Beyond the reversion to the green color, of genetic origin, they have been also told to changes in the morphologic characteristics of the plant such as alteration of the serrated margin of of leaves, texture and structure of the base of the foliar limb, reduction in the speed of the growth of the plant, alteration of the color in accordance with the luminous intensity of the environment. Two assays on the subject had been carried through, in conditions of vegetation house. Seeds of six accesses of Ocimum basilicum of purple color acquired in the formal commerce (Dark Opal, Purple and Ruby) and reproduced localy, (Purple Rufles, Local Ornamental and Local Hortaliça) had been cultivated in vegetation house in the Experimental Station of Biology of the University of Brasilia. The analysis of the expression of the purple color in seedlings was accomplished fifteen days after germination, when the plants already expressed the anthocyanin genes, with the purpose to check the regression to the green color, besides, had its development followed and analyzed to determine the influence of the regression for the green color in some agronomic characteristics. The standard of growth and development as well as the dry mass of the aerial part of the plants had been analyzed statistical. One concluded that the regression to the green color is bigger in the second the cycle of each sowing. In the access Local Hortaliça it did not have regression to the green color. It had difference of vigor between plants turned to the green color and the purple ones in the access Purple Ruffles, being the the green plants more vigorous. It has a definite or regular standard of regression the green color only in the access Local Ornamental, always following the ribbings of the foliar limb, in contrast of the too much accesses. The capacity of bloom and production of seeds was lesser in the access Local Hortaliça. The vegetative propagation follows being the classic recommendation to skirt the regression to the green color in cultivating them of purple basil.

Key words: Ocimum basilicum, purple basils, anthocyanin, instability. 


\section{INTRODUÇÃO}

O gênero Ocimum possui uma característica de bastante importância para o comércio de plantas ornamentais e para a indústria de corantes e cosmética, que é a variação de cor em variedades purpuras. Característica essa que se deve ao fato de a espécie ser abundante fonte de antocianinas, responsáveis pelas cores que variam do vermelho ao azul em plantas, folhas, frutos e flores. Os manjericões de cor púrpura são valorizados não somente como fonte de antocianinas, mas particularmente como plantas ornamentais (SANTOS, 2007).

As antocianinas são glicosídeos que apresentam moléculas de açucares ligados à sua estrutura e, na ausência desses açúcares, são conhecidas como antocianidinas. A cor da antocianina é influenciada por diversos fatores, tais como: número de grupos hidroxila $(-\mathrm{OH})$ e metoxila $(-\mathrm{OCH} 3)$, presença de ácidos aromáticos esterificados ao esqueleto principal e $\circ \mathrm{Ph}$ do vacúolo, onde tais compostos são armazenados. Ou seja, o aumento de número de grupos hidroxila altera a absorção para um comprimento de onda mais longo, o que resulta na cor azul, enquanto que a substituição do grupo hidroxila por um grupo metoxila altera a absorção para um comprimento de onda um pouco mais curto que resulta na cor avermelhada (OZELA, 2006; SANTOS, 2007).

A maior dificuldade para o mercado é a estabilidade da coloração roxa para que manjericões de cor purpura sejam utilizados para a indústria ornamental e de alimentos. Essa talvez seja a particularidade mais interessante da antocianina: sua capacidade de mudança de coloração com o pH do meio (BROUILLARD E DUBOIS, 1977). Além disso, vários estudos demonstram que autopolinizações das plantas roxas em consecutivas gerações não estabilizam a expressão da antocianina DARRAH (1974; 1980).

A expressão da antocianina é controlada por dois genes, e a instabilidade desses genes é tão grande que, segundo PHIPPEN E SIMON (2000), as variedades roxas de manjericão têm aproximadamente $34 \%$ de reversão para a cor verde ou com manchas verdes, independentemente do número de autopolinizações. Além disso, durante a reversão da cor roxa para a verde, outras características das folhas mudaram tais como: as serras nas margens, textura e estrutura da base; as plantas roxas tiveram o crescimento mais lento, provavelmente a produção de antocianina que demanda mais energia; as folhas apresentaram uma coloração mais intensa e escura do roxo sob condições de luz forte, o que levou a concluir que ambientes sombreados 
levam à degradação da antocianina, facilitando a mudança para a cor verde de folhas localizadas nas partes mais baixas e internas da planta; foi observado também que a expressão da antocianina é dominante sobre o verde em todas as plantas que a contém e também que a antocianina é muito facilmente perdida, pois em plantas verdes nunca se tornaram roxas em seu crescimento, enquanto que foi comum plantas roxas se tornarem parcialmente verdes (PHIPPEN E SIMON, 2000).

CARVALHO (2002), trabalhando em casa de vegetação com $50 \%$ de sombra o acesso Rubi da firma Feltrin, encontrou em média 28\% de reversão parcial à cor verde em plantas de manjericão roxo oriundas de sementes adquiridas no comércio formal. As plantas oriundas das sementes de segunda geração apresentaram um índice de regressão 25\% maior. Observou que as plantas roxas apresentaram crescimento mais lento em relação às plantas verdes. Nas plantas roxas a floração e produção de sementes atrasou vintes dias em média em relação às plantas verdes. O serreado da margem do limbo foliar para menos, bem como a estrutura de sua base e a textura também foram alterados acompanhando a perda da cor roxa. Observou que o sombreamento parcial da casa de vegetação interferiu na manutenção da prevalência da cor roxa com o passar do tempo, tendo havido ausência de padrão morfológico específico para a folhas verdes.

No presente trabalho, foram realizados ensaios para avaliar o comportamento de cultivares de Ocimum basilicum de cor púrpura em casa de vegetação, identificando-se as características morfológicas afetadas pelos diferentes níveis de expressão da cor roxa, sua estabilidade, bem como o efeito da reversão à cor verde no crescimento e desenvolvimento da planta. 


\section{MATERIAL E MÉTODOS}

Sementes e mudas de acessos de Ocimum basilicum de cor roxa adquiridas no comércio formal (mercado) e outras reproduzidas localmente, foram cultivadas em casa de vegetação na Estação Experimental de Biologia da UnB (Tabela 1). As condições de casa de vegetação tipo glasshouse foram: $40 \%$ de sombra medida por fotômetro Asahi Pentax SP-500, temperatura média do ambiente durante ao ensaio registrando média das mínimas em $17,5^{\circ}$.C e das máximas em $36,5^{\circ}$.C, medida por termômetro convencional de máxima e mínima. O delineamento experimental utilizado foi o de blocos inteiramente casualizados. Os instrumentos empregados para aferir a medida das plantas foram: bastão graduado e balança eletrônica de alta precisão 40kg. As análises estatísticas presentes neste trabalho foram executadas pelo programa estatístico Genes.

ENSAIO 1 - Estudo da regressão à cor verde em cinco acessos de manjericão roxo em Brasília.

Em um primeiro ensaio, com a finalidade de se determinar o grau de regressão dos acessos de manjericão roxo à cor verde, as sementes de seis acessos (Tabela 2) foram semeadas em vasos de $3 \mathrm{~L}$ de capacidade contendo a mistura EEB. A Mistura EEB constou de latossolo vermelho de cerrado mais areia, vermiculita e composto orgânico respectivamente na proporção 3:1:1:1, mais a formulação 4-14-8, na dose de $100 \mathrm{~g}$ para cada $40 \mathrm{~L}$ da mistura. A Mistura EEB em análise por amostragem apresentou a seguinte composição média: matéria orgânica, 8,2\%; nitrogênio, 0,52\%; fósforo total $0,21 \%$; potássio $0,46 \%$; carbono orgânico $4,8 \%$; relação $\mathrm{C} / \mathrm{N}, 9,2 ; \mathrm{pH}=$ 6,2 . 
Tabela 2. Acessos de Ocimum basilicum pesquisados, identificação e procedência.

\begin{tabular}{cc}
\hline Acesso & Origem/ Firma \\
\hline Dark Opal & Top Seed $\left({ }^{1}\right)$ \\
Local hortaliça & Sítio Corujinha $-\mathrm{DF}\left({ }^{3}\right)$ \\
Local ornamental & Holambra- EEB $\left({ }^{2}\right)$ \\
Purple Ruffles & Holambra - EEB $\left({ }^{2}\right)$ \\
Roxo & Feltrin $\left({ }^{1}\right)$ \\
Rubi & Isla $\left({ }^{1}\right)$
\end{tabular}

$\left({ }^{1}\right)$ sementes adquiridas no comércio formal, $\left({ }^{2}\right)$ sementes obtidas a partir de mudas adquiridas no comércio formal, $\left({ }^{3}\right)$ acesso de florescimento raro. Mudas produzidas por estaquia

Invariavelmente, aos quatro dias da semeadura tinha início a germinação. A análise da expressão da cor roxa nos seedlings se dava no décimo quinto dia, quando as plantas, reagindo à luminosidade da casa de vegetação, já expressavam os genes de antocianina.

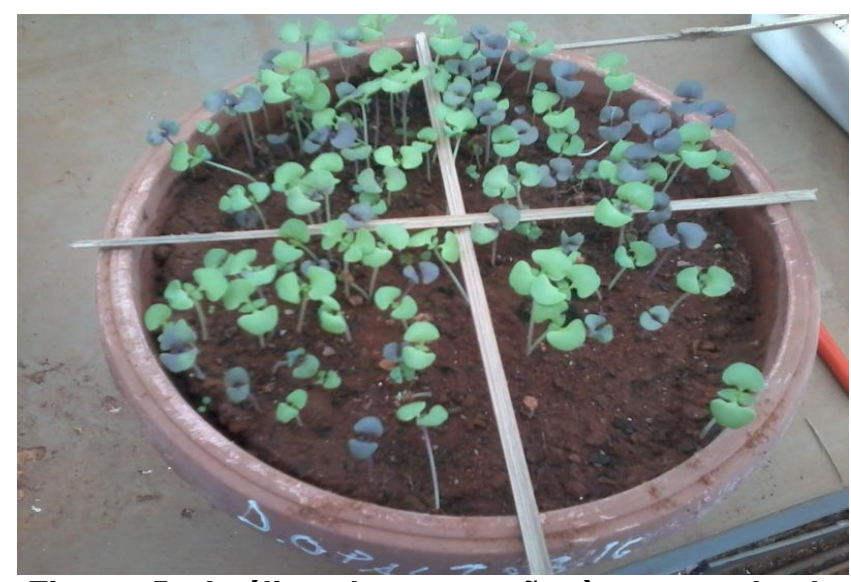

Figura 5. Análise da regressão à cor verde de seedlings de acessos de manjericões roxos. A área do vaso era dividida em quadrantes, para facilitar a contagem.

A análise era feita dividindo a área do vaso em quadrantes (Figura 5), o que facilitava a contagem. Cada acesso foi semeado três vezes. Foram semeadas as sementes convencionais de tradicionais marcas comerciais para um primeiro ciclo, coletavam-se as sementes desse ciclo para o semeio de segundo ciclo, com a finalidade de aferir a regressão à cor verde. As sementes dos acessos não disponíveis no comercio formal e que são comercializados na forma de mudas tiveram que ser obtidas a partir da própria muda ao completar o seu ciclo reprodutivo. Foram eles: Local hortaliça, Local ornamental e Purple Rufles. Os seedlings dos acessos roxos 
obtidos foram analisados visualmente quanto à expressão da cor roxa sendo registrados os números de plantas verdes e roxas.

As contagens eram transformadas em percentagens e transformadas em arcsen $\%{ }^{\wedge} 0,5$ para análise da variância e separação das médias pelo teste de Tukey, a partir do programa genes.

Para um dos acessos (Purple Rufles), mudas de cada padrão (verde e roxo), após individualizadas em vasos, tiveram seu desenvolvimento acompanhado e analisado para se determinar a influência da regressão para a cor verde em algumas características agronômicas.

Quarenta dias após a germinação na sementeira, as mudas foram transplantadas para vasos de $3 \mathrm{~L}$ de capacidade, preenchidos com a Mistura EEB, para o acompanhamento do seu desenvolvimento. Neste segundo ensaio, foram analisados estatisticamente o padrão de crescimento e desenvolvimento das plantas, bem como a massa seca da parte aérea das mudas. Os dados para a curva de crescimento foram obtidos das dez (10) melhores plantas de cada tratamento e para o peso seco ao final do ensaio, das cinco (5) melhores plantas.

\section{Ensaio 2 EFEITO DA REGRESSÃO À REGRESSÃO À COR VERDE NA PRODUÇÃO DE MUDAS DE MANJERICÃO ROXO}

Sementes e mudas de acessos de Ocimum basilicum de cor roxa adquiridas no comércio formal (mercado) e outras reproduzidas localmente, foram cultivadas em casa de vegetação na Estação Experimental de Biologia da UnB. As condições de casa de vegetação foram iguais a do primeiro ensaio.

Para um dos acessos (Purple Rufles), mudas de cada padrão (verde e roxo), após individualizadas em vasos, tiveram seu desenvolvimento acompanhado e analisado para se determinar a influência da regressão para a cor verde em outras características agronômicas.

Providenciou-se o semeio em caixas sementeiras. Quarenta dias após a germinação, as mudas foram individualizadas e transplantadas para vasos de $3 \mathrm{~L}$ de capacidade, preenchidos com a Mistura EEB, para o acompanhamento do seu desenvolvimento durante cinco semanas após o transplante.

Neste ensaio, foram analisados estatisticamente o padrão de crescimento e desenvolvimento bem como a massa seca da parte aérea das mudas ao final do 
ensaio. Através do programa genes, foram realizadas análise da variância e separação das médias pelo teste de Tukey. A caracterização morfológica das plantas deste ensaio foi feita nas dez (10) melhores plantas representativas de cada padrão de planta e a massa seca foi determinada nas cinco (5) melhores plantas. 


\section{RESULTADOS E DISCUSSÃO}

ENSAIO 1 - Estudo da regressão à cor verde em cinco acessos de manjericão roxo em Brasília.

Os resultados referentes ao Ensaio 1 encontram-se representados na Tabela 3 que apresenta as percentagens de regressão à cor verde de acessos de manjericão roxo encontrados em Brasília.

Tabela 3. Regressão à cor verde em plantas originadas da semeadura de acessos de manjericão roxo. Brasília, 2017.

\begin{tabular}{ccc}
\hline & \multicolumn{2}{c}{ Cor de folhas predominante nas mudas (\%) } \\
\cline { 2 - 3 } Acessos & Roxa & Verde \\
\hline Roxo Feltrin & $73,74 \mathrm{a}$ & $16,14 \mathrm{~b}$ \\
Local Hortaliça & $100,00 \mathrm{a}$ & $0,00 \mathrm{~b}$ \\
Dark Opal Top Seed & $72,1 \mathrm{ab}$ & $17,76 \mathrm{~b}$ \\
Rubi Isla & $58,06 \mathrm{ab}$ & $31,86 \mathrm{ab}$ \\
Local Ornamental $\left({ }^{(}\right)$ & $56,7 \mathrm{ab}$ & $33,23 \mathrm{ab}$ \\
Roxo Feltrin $\left({ }^{(}\right)$ & $53,75 \mathrm{ab}$ & $36,18 \mathrm{ab}$ \\
Rubi Isla $\left({ }^{1}\right)$ & $40,27 \mathrm{~b}$ & $49,67 \mathrm{ab}$ \\
Dark Opal Top Seed $\left({ }^{1}\right)$ & $34,14 \mathrm{~b}$ & $55,85 \mathrm{a}$ \\
Purple Ruffles BSB $\left({ }^{1}\right)$ & $30,70 \mathrm{~b}$ & $59,08 \mathrm{a}$ \\
CV & 19,03 & 26,8 \\
DMS Tukey & 28,23597 & 28,41687
\end{tabular}

1 indica sementes produzidas na própria estação experimental. As demais sementes foram adquiridas no comércio formal. Para efeito de análise estatística os dados originais foram transformados em Arcsen.\%^0,5. DMS indica Diferença Mínima Significativa, CV indica coeficiente de variação.

*Médias com a mesma letra não diferem entre si no teste de comparação de médias Tukey, a 5\% de probabilidade.

Ao observar a Tabela 3, conclui-se que nas sementes adquiridas no comércio formal a regressão tende a ser menor que nas sementes de produção própria, ou aquelas chamadas "de segundo ciclo". As sementes da cultivar Purple Rufles obtidas somente a partir de mudas adquiridas em viveiros e não de sementes comerciais, apresentaram a mais forte regressão, muito embora tenha diferido estatisticamente apenas do Roxo Feltrin comercial, o acesso de melhor desempenho.

O acesso Roxo Feltrin foi estatisticamente superior a Rubi Isla (e), Dark Opal Top Seed (e) e Purple Rufles (e) esses últimos oriundos de sementes de produção local. Sementes do acesso Roxo Feltrin, mesmo produzidas localmente, ou seja, de "segunda geração", apresentaram índice de regressão relativamente mais baixo que 
as demais na mesma condição, não diferindo sua percentagem de plantas roxas estatisticamente, em relação àquela de suas sementes comerciais.

$\mathrm{Na}$ Tabela 3 foi possível observar que as médias das características mensuradas foram divididas em dois grupos distintos, $a$ e $b$, mostrando diferenças estatísticas na regressão à cor verde dos acessos utilizados no ensaio. A cultivar Roxo Feltrin apresentou maior quantidade de folhas roxas, diferindo da Purple Rufles BSB, com $30,70 \%$ de folhas roxas, a menor porcentagem dentre os acessos avaliados. É importante salientar que a Roxo Feltrin era uma cultivar comercial, e a Purple Rufles BSB um acesso produzido em ciclos de produção na Estação Experimental de Biologia da Universidade de Brasília.

Outro ponto importante apresentado na Tabela 3 tem relação com os coeficientes de variação das características avaliadas que foram menores que $30 \%$. Esse fato demonstra boa precisão experimental, indicando boa condução do experimento de forma geral.

SANTOS (2007), exercitando cruzamentos com manjericões roxos em Brasília observou que a progênie do segundo ciclo sempre "segregava" favoravelmente para a coloração verde. Vários estudos demonstram que autopolinizações das plantas roxas em consecutivas gerações não estabilizam a expressão da antocianina DARRAH (1974; 1980).

Segundo estudos anteriores, há uma clara sinalização de que as sementes comerciais em geral apresentam as mais baixas taxas de regressão à cor verde no primeiro semeio, porém, nos semeios seguintes a taxa de regressão se eleva bastante, indicando que há, por meio das empresas, algum meio de controle de qualidade ou seleção para a comercialização de sementes, tendo em vista que a preservação da característica roxa tem mais sucesso na multiplicação por estaquia.

Um outro manjericão participante do elenco de manjericões roxos é o Local Hortaliça, o manjericão mais popular no Distrito Federal, que apresenta a cor roxa apenas no talo, no pecíolo e na inflorescência, não sendo a cor roxa aparente no limbo foliar. Apresenta escasso florescimento mas produz sementes férteis. Não foi observada qualquer regressão à cor verde neste acesso (Figura 6). 


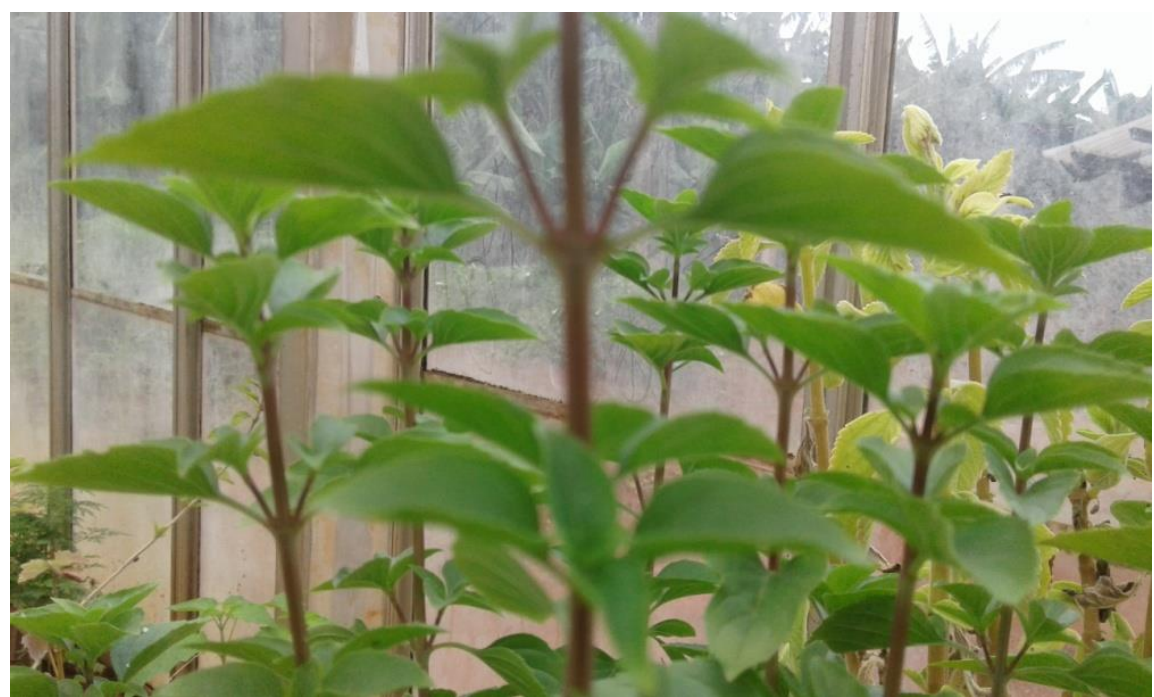

Figura 6. Acesso Local Hortaliça de Brasília. Ausência de regressão à cor verde. Brasília, 2017. Fonte: Autor.

O acesso Local Ornamental, contrariando observações anteriores por CARVALHO (2000) em manjericões roxos, apresentou um padrão definido de descoloração. Neste acesso, a cor roxa se dá ao lado das nervuras e ao longo delas. Plantas regredidas não apresentam manchas verdes isoladas e ao acaso ocupando o limbo foliar conforme observado nos outros acessos roxos. Nele a descoloração de dá de forma regular ao longo das nervuras.

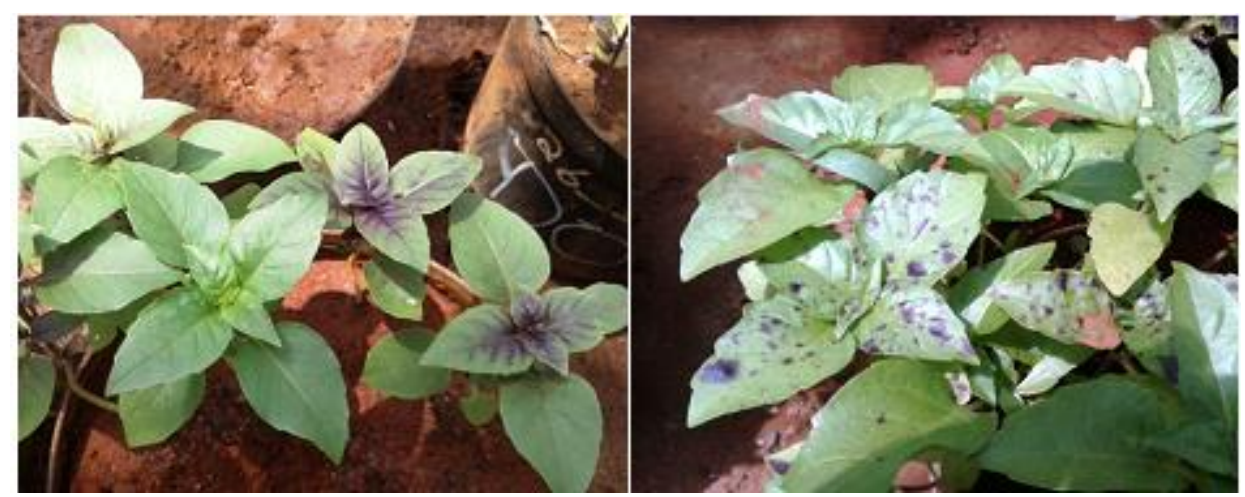

Figura 7. Padrão regressão à cor verde em dois acessos de manjericão roxo. À esquerda, Ornamental BSB e à direita, Purple Rufles. Brasília, 2017. Fonte: Autor.

A regressão à cor verde tem sido um problema para os produtores de mudas e sementes de manjericões roxos. A clorofila, que causa a cor verde na maioria de plantas, é encontrada nos plastídeos, no protoplasma da planta. Os pigmentos responsáveis pelas cores vermelho e roxo (antocianinas) por outro lado, são solúveis 
em água, como um corante, e são encontrados nas células da epiderme ou da superfície das folhas mais que nas células internas onde a clorofila está. Nas plantas com pigmentação roxa forte, o verde é obscurecido completamente por esta sobrecamada de conteúdos celulares coloridos; em outros casos, é somente matizado ou mascarado parcialmente. Os pigmentos roxos podem também ocorrer como cristais no suco celular de células epidermais, causando a aparência reluzente das folhas de alguns manjericões (DeBAGGIO, 1994).

A biossíntese de pigmentos antociânicos em plantas requer uma interação complexa entre duas categorias de genes: estruturais e regulatórios (SANTOS, 2007). Conforme observado por (PHIPPEN, 1999; PHIPPEN E SIMON, 2000; CARVALHO, 2002) as plantas verdes nunca se tornam roxas em seu crescimento, além de a presença de manchas roas em plantas quase totalmente verdes indica que os genes de expressão da antocianina estão presentes na planta, conforme ocorreu neste experimento (Figura 7).

A produção de pigmentos roxos é hereditária nas plantas. Embora firme em algumas variedades (tais como o repolho vermelho e o amaranto vermelho) é incerta em algumas outras (manjericões, por exemplo), sugerindo que diversos genes podem ser responsáveis para sua presença. Os genes responsáveis pela cor roxa no manjericão (Ocimum basilicum L.) parecem ser de tal forma instáveis que mesmo as plantas propagadas vegetativamente podem perder sua cor roxa (DeBAGGIO, 1994).

Plantas púrpuras autopolinizadas por várias gerações não mostraram uma expressão de antocianina estável. Os resultados do completo cruzamento de dialelos indicou que a expressão de antocianina nos tecidos vegetativos é controlada por dois genes (PHIPPEN E SIMON 2000).

A estabilidade da cor púrpura, mesmo em clones obtidos por estaquia, é afetada pelo ambiente e pelo local na planta de onde se tiram as estacas. A detecção de um acúmulo de metabólitos secundários (apigenina, genisteína e kaempferol) em setores revertidos para o verde nas folhas roxas, sugere um potencial bloqueio na via metabólica da antocianina. Foi formulada a hipótese de que a mutação de reversão ocorre em um gene regulador de antocianina (PHIPPEN E SIMON, 2000; CARVALHO, 2002).

Sob condições de luz forte, as folhas apresentam uma coloração de roxo mais escuro. O sombreamento leva à degradação da antocianina, fazendo com que as folhas localizadas nas partes mais baixas e mais internas sejam mais verdes. A 
produção de antocianina é instável e muito facilmente perdida, porém, muito dificilmente adquirida. Plantas verdes nunca se tornam roxas em seu crescimento, por outro lado, é comum plantas roxas tornarem-se parcialmente verdes. A presença de manchas roxas em plantas quase totalmente verde indica que os genes responsáveis pela expressão da antocianina estão ainda presentes na planta (PHIPPEN, 1999; PHIPPEN E SIMON, 2000; CARVALHO, 2002).

\section{Ensaio 2 EFEITO DA REGRESSÃO À REGRESSÃO À COR VERDE NA PRODUÇÃO DE MUDAS DE MANJERICÃO ROXO}

O ensaio de crescimento de plantas do acesso Purple Rufles apresentou os resultados expressos nas Figuras 8 e 9, que apresentam respectivamente a foto das mudas e o gráfico do crescimento de plantas de Ocimum basilicum cv. Purple Rufles em seis semanas de cultivo em casa de vegetação, relativo à cor da planta.

Observando o gráfico, pode-se verificar que já ao momento do transplante (Figura 9), as mudas de cor roxa apresentavam menor tamanho, com média em torno de $20 \mathrm{~cm}$, enquanto as plantas de cor predominante verde apresentavam média de altura de $30 \mathrm{~cm}$.

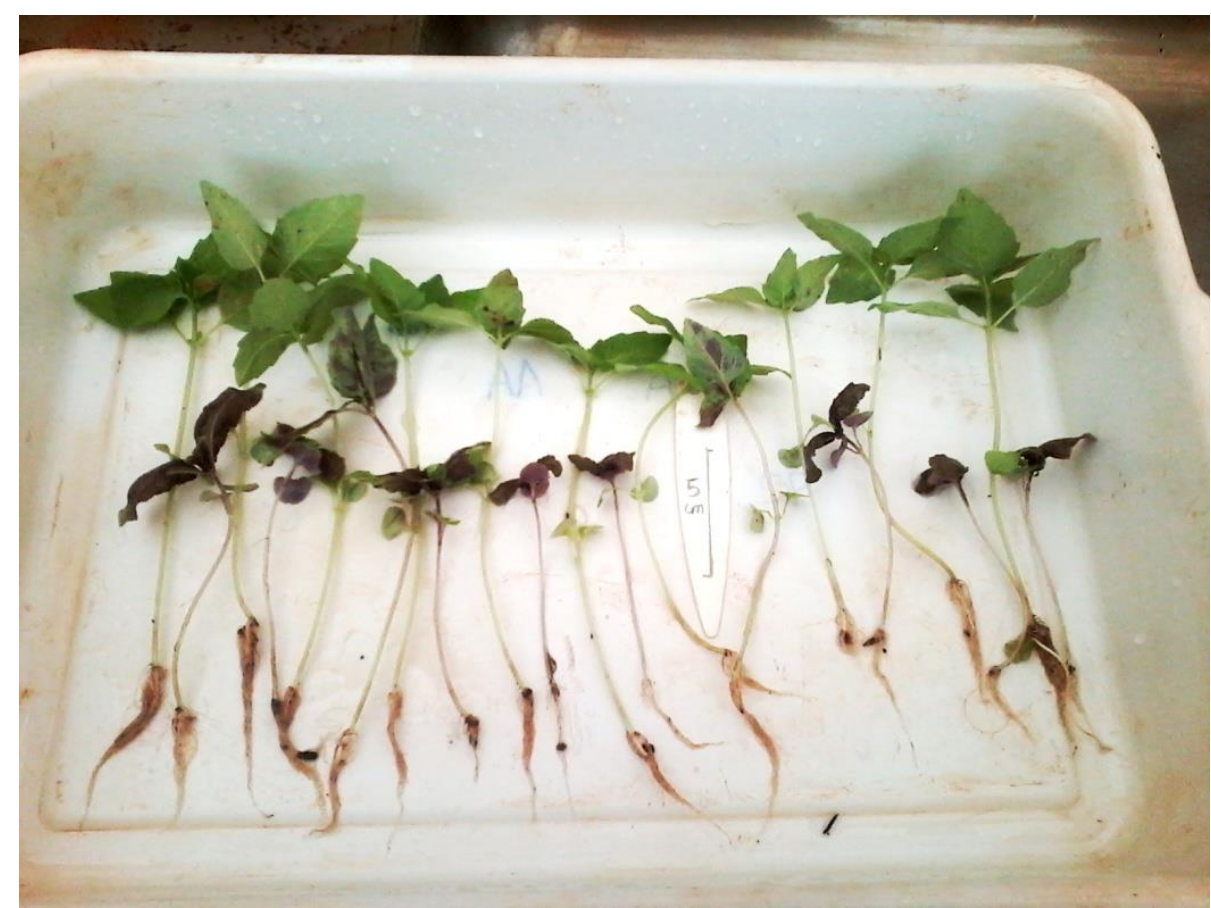

Figura 8. Fotografia ilustrativa da diferença de tamanho entre mudas de Ocimum basilicum cv Purple Rufles de cor roxa e as mudas regredidas à cor verde ao momento do transplante. Brasilia, 2017. 
Ao final do ensaio, quando as plantas já iniciavam a formação de sementes, a altura média das plantas verdes estava próximo de $67 \mathrm{~cm}$, enquanto a altura média das plantas roxas estava em torno de $40 \mathrm{~cm}$.

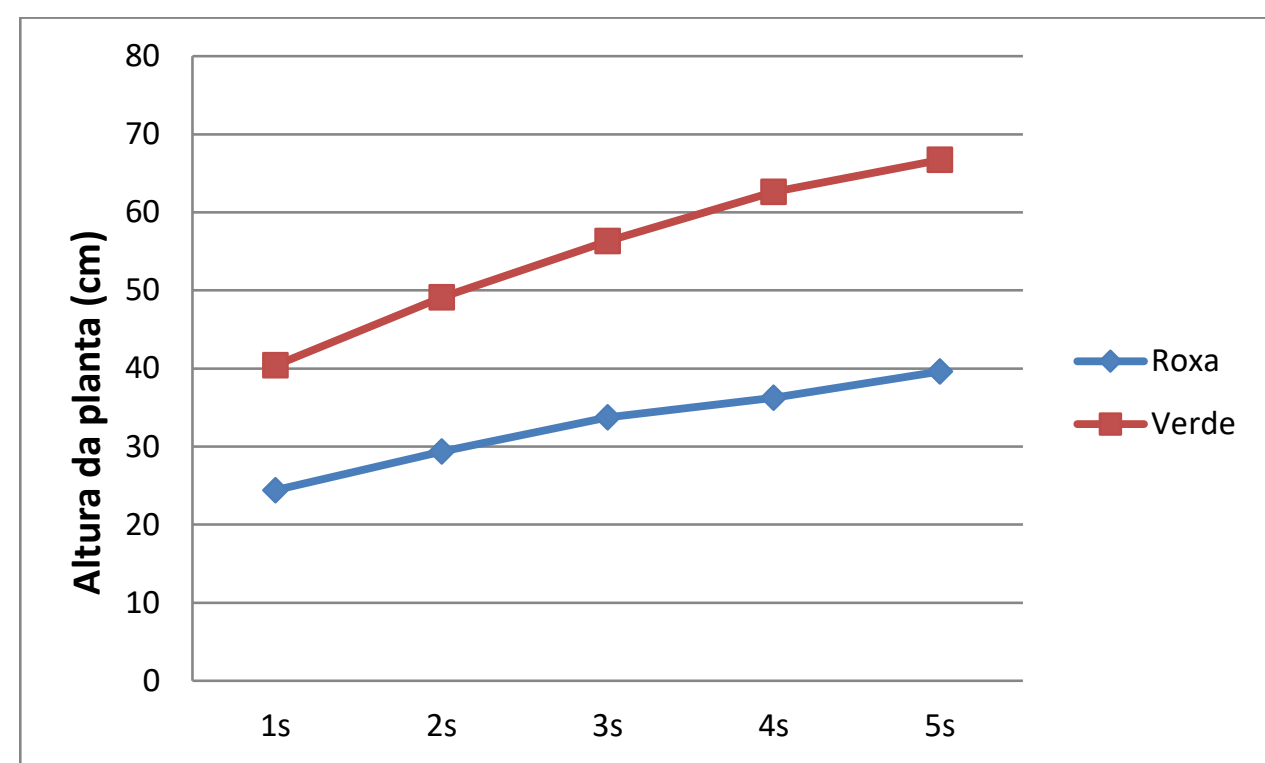

Figura 9. Curva de crescimento de plantas de Ocimum basilicum cv. Purple Rufles em cinco semanas de cultivo em casa de vegetação, relativa à cor da planta.

A taxa média diária de crescimento das plantas, apresentada na Figura 6, mostra que a taxa de crescimento em centímetros por dia esteve em torno de 1,3 da primeira para a segunda semana para as plantas verdes e 0,7 para as plantas roxas, decrescendo a partir daí até à quarta e quinta semanas, onde caiu para 0,5 nas plantas roxas e 0,6 nas plantas de cor predominantemente verdes. 


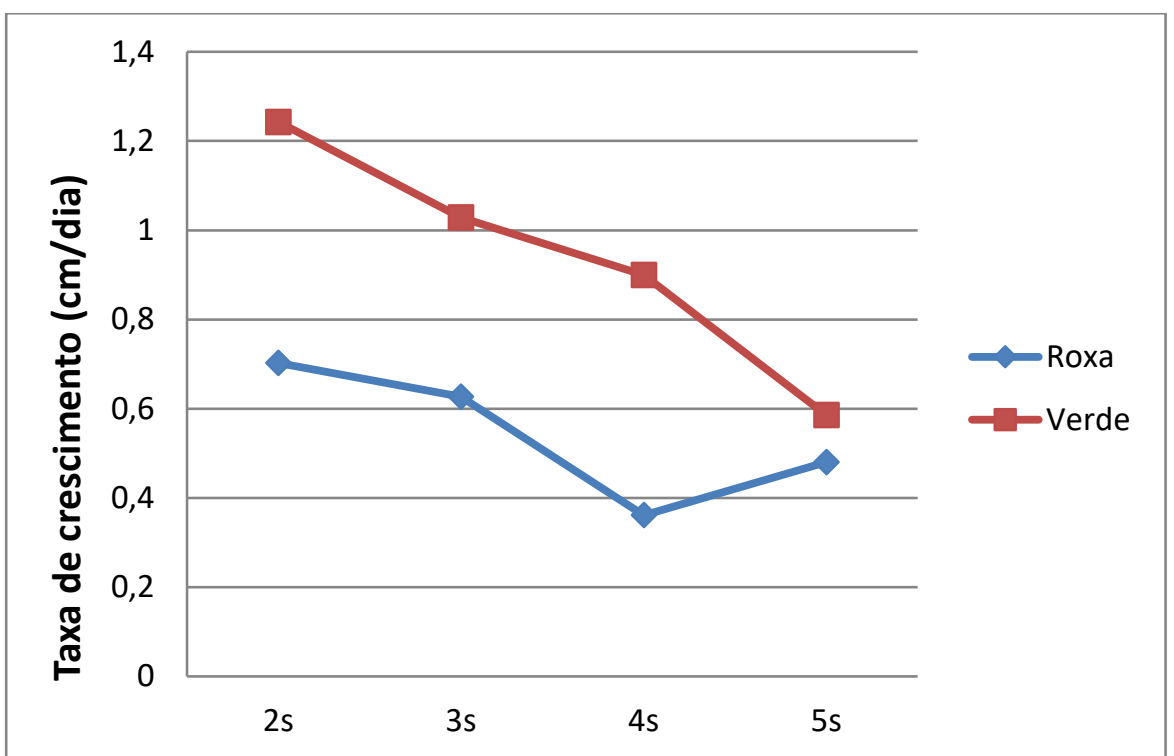

Figura 10. Taxa média diária de crescimento de plantas de Ocimum basilicum cv. Purple Rufles em cinco semanas de cultivo em casa de vegetação, relativo à cor da planta.

Observou-se durante o ensaio que nas plantas que regrediram à cor verde, uma característica básica da cultivar Purple Rufles, qual seja a crisposidade das folhas, encontrava-se praticamente ausente, conforme pode ser visto na Figura 11, que apresenta a fotografia do ensaio em seu momento de maior vigor vegetativo.

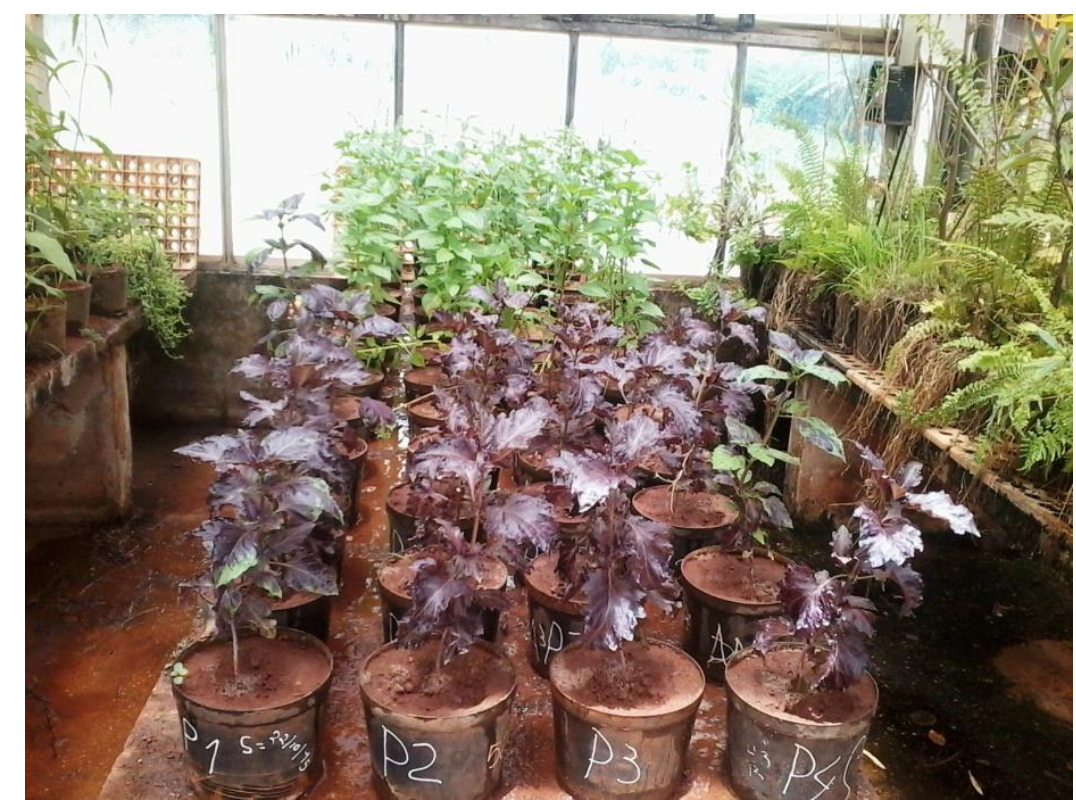

Figura 11. Aspecto do ensaio de crescimento de plantas de Ocimum basilicum cv. Purple Rufles relativo à cor da planta. Note-se a crisposidade evidente nas plantas roxas contrastando com sua quase ausência nas plantas verdes. Brasília, 2017. Fonte: Autor. 
A cor púrpura e à crisposidade da folha foram estudados por PHIPPEN E SIMON (2000) que investigaram a herança e os padrões de estabilidade de características das folhas usando a variedade Purple Ruffles. O resultado refere-se ao cruzamento completo de dialelos indicando que a expressão de antocianina nos tecidos vegetativos é controlada por dois genes e a textura encrespada da folha é controlada por um único gene recessivo.

Semelhante ao ocorrido no presente trabalho, a alteração de outras características morfológicas em manjericões roxos, além da cor púrpura, tem sido observada por outros autores em plantas que regrediram à cor verde. CARVALHO (2000), trabalhando em casa de vegetação com o acesso Rubi (Feltrin@), observou que as plantas roxas apresentaram crescimento mais lento em relação às plantas verdes. Nas plantas roxas a floração e a produção de sementes atrasaram vintes dias em média em relação às plantas verdes. NURZYŃSKA-WIERDAK (2007), pesquisou vários cultivares de manjericão, entre eles Purple Rufles, e concluiu que o número dos dias até o florescimento depende das condições de tempo e da cultivar, variando de 44 a 126 dias, tendo a cultivar "Minimum" sido mais precoce que Purple Rufles. Indica ainda que maior precocidade no florescimento podem ser um resultado de temperaturas baixas no início do crescimento de planta.

PHIPPEN E SIMON (2000) observaram na cultivar Purple Rufles, que os genes que controlam a margem do limbo foliar e a estrutura da base da folha estão ligados à textura da mesma, o que dá coerência aos resultados de CARVALHO (2000) que observou na cultivar Rubi, que o serreado da margem do limbo foliar, bem como a estrutura de sua base e a textura, foram sensivelmente alterados com a perda da cor púrpura. Os mesmos autores indicam que a reversão à cor verde não afetou a produção de óleo essencial e seus constituintes. Não fazem referência, no entanto, à influência da reversão sobre o crescimento e desenvolvimento das plantas, que é o tema do presente ensaio. A experimentação daqueles autores não tratou explicitamente de diferenças no vigor, no desenvolvimento e no porte das plantas. 
Tabela 4. Diferença de massa fresca e seca, altura na época de florescimento e semanas para o florescimento de variedades roxas e verdes. Brasília, 2017.

\begin{tabular}{ccccc} 
& Massa fresca $(\mathrm{g})$ & Massa seca $(\mathrm{g})$ & $\begin{array}{c}\text { Altura no } \\
\text { florescimento }\end{array}$ & $\begin{array}{c}\text { Semanas para } \\
\text { florescimento }\end{array}$ \\
\hline Roxas & 57 & 40 & 66,4 & 8 \\
Verdes & 17,43 & 12,41 & 94 & 14 \\
\hline
\end{tabular}

Ao final do presente ensaio a massa seca das plantas roxas (média das cinco maiores plantas) foi em média $12,41 \mathrm{~g}$ e a das plantas verdes, 17,43 g, estatisticamente diferentes pelo teste $\mathrm{F}$, com $26 \%$ de coeficiente de variação.

Em nossos resultados se confirma a descrição de DeBAGGIO (1994) para a cultivar Purple Rufles, como sendo uma planta de aproximadamente de $61 \mathrm{~cm}$ de altura, com folhas largas de cor púrpura brilhante, curvas e crespas, com margens finamente lobuladas. De Baggio relata ainda que em tempos recentes, viveiristas têm relatado a degradação das características da cultivar em partidas de sementes.

Algumas características das plantas observadas no presente ensaio, diferem da proposta de SIMON et al. (1999), no tocante à altura da planta e dias para florescimento. Aqueles autores referem à cultivar Purple Rufles como plantas com 34 $\mathrm{cm}$ de altura, com diâmetro da parte aérea de $29 \mathrm{~cm}$. Nossos resultados para altura estão mais próximos de DeBAGGIO (1994), com $61 \mathrm{~cm}$. Seriam 134 dias para florescimento segundo SIMON et al. (1999), quando o observado em nosso ensaio, realizado no período seco e frio com dias curtos de Brasília, foi de aproximadamente 68 dias para o início do amadurecimento das sementes, coincidindo com o final do presente ensaio de crescimento. As demais características coincidiram. Diferenças nos ambientes de cultivos certamente poderiam explicar as discrepâncias. 


\section{CONCLUSÕES}

1. A regressão é maior no segundo ciclo de cada semeadura.

2. No acesso Local Hortaliça não houve regressão à cor verde.

3. Há diferença de vigor entre plantas regredidas a cor verde e não regredidas na cultivar Purple Ruffles.

4. Há padrão definido de regressão a cor verde apenas na cultivar Local Ornamental - sempre nas nervuras.

5. Observou-se diferenças na capacidade de florescimento e produção de sementes, que foi menor na cultivar Local Hortaliça. 


\section{REFERÊNCIAS BIBLIOGRÁFICAS}

BROUILLARD, R., DUBOIS, J. E. Mechanism of the Structural Transformations of Anthocyanins in Acidic Media,J. Am. Chem. Soc. (USS), v.99, p.1359, 1977.

CARVALHO, F. H.. Variação da pigmentação em seedlings de Ocimum basilicum L var. purpurascens. Universidade de Brasília - Faculdade de Agronomia e Medicina Veterinária. 2002. 28 p.. Monografia de Graduação em Agronomia.

DARRAH, H. 1974. Investigations of the cultivars of basils (Ocimum). Econ. Bot. 28:6367.

DARRAH, H. 1980. The cultivated basils. Buckeyey Printing Co., Mo. 40 p.

$\begin{array}{lllll}\text { DeBaggio, } & \text { T. } & \text { Growing } & 1994\end{array}$ http://www.motherearthliving.com/gardening/purple-basils. Acessado em janeiro de 2017.

Nurzyńska-Wierdak, R. Comparing the growth and flowering of selected basil (Ocimum basilicum) varieties. Acta Agrobotanica, v.60, n. 2: p. 127-131. 2007

OZELA, E.F. Caracterização de flavonoides e estabilidade de pigmentos de frutos de Bertalha (Basella rubra L.). Universidade Federal de Viçosa. 2007. $71 \mathrm{fl}$. Tese de Doutorado.

PHIPPEN, W.B. Anthocyanin instavility in basil (Ocimum basilicum L.). 1999. 184 p. PhD Dissertation - Purdue University, Purdue, 1999.

PHIPPEN WB and SIMON JE. Anthocianin Inheritance and Instability in Purple Basil. The Journal of Heredity 2000: 91 (4).

SANTOS, E. F. Seleção de tipos de Ocimum basilicum L. de cor púrpura para o mercado de plantas ornamentais. 2007. 58 f. Dissertação (Mestrado em Agronomia) Universidade de Brasília, Brasília, 2007.

Simon, J. E., Morales, M. R., Phippen, W. B., Vieira, R. F., e Hao, Z. (1999). Basil: a source of aroma compounds and a popular culinary and ornamental herb. Perspectives on new crops and new uses, In: Janick, J. (ed.) Perspectives on new crops and new uses. ASHS Press: Alexandria, p. 499-505. 


\section{CAPítulo 2}

COMPOSIÇÃO DO ÓLEO ESSENCIAL, RENDIMENTO DE GENÓTIPOS DE MANJERICÕES CULTIVADOS NO DISTRITO FEDERAL 


\section{DESCRIÇÃO, COMPOSIÇÃO DO ÓLEO ESSENCIAL, RENDIMENTO DE GENÓTIPOS DE MANJERICÕES CULTIVADOS NO DISTRITO FEDERAL}

\section{RESUMO}

O manjericão (Ocimum basilicim) é largamente utilizado na medicina popular e seu óleo essencial tem grande valor de mercado. Também há bastante interesse em sua utilização para fins ornamentais e, para isso, além de características morfológicas diversas como a conformação de folhas, plantas e inflorescências, a cor também se tornou um objeto de estudo devido algumas variedades possuírem a coloração roxa. Foram avaliadas a composição química do óleo essencial de cinco genótipos de Ocimum basilicum, rendimento de óleo cinco genótipos roxos e um verde, cultivados no DF, com o objetivo de identificá-los e estimar seu potencial no mercado ornamental, alimentício e cosmético. As extrações foram realizadas por hidrodestilação em aparelho Clevenger modificado e a análises foram realizadas em cromatógrafo Shimadzu, GC 17A. Os compostos majoritários e os demais compostos em maior quantidade encontrados no óleo essencial do acesso Purple Ruffles foram metil-chavicol $(55,15 \%)$ fenchona (23,36\%), a trans bergamoteno (6,27\%), 1,8-cineol (3,3\%) e a cadinhol (3\%). Para o acesso Dark Opal: linalol (52,8\%), a trans bergamoteno (12,5\%), 1,8-cineol $(8,8 \%)$, a cadinol $(3,4 \%)$ e eugenol $(2,85 \%)$, enquanto que para o acesso Local Hortaliça obteve-se: linalol (35,9\%), eugenol (28,9\%), 1,8-cineol $(8,1 \%)$ e a cadinol (6,9\%). Para o genótipo Rubi: linalol (54,5\%), eugenol (6,7\%), germacreme D (5\%), a cadinol (5\%), 1,8-cineol (3,5\%). No genótipo Citral obteve-se Geranial (40,7\%), neral (32\%), nerol $(4,3 \%)$ e linalol $(4 \%)$. Os resultados referentes ao rendimento dos oléos essenciais obtidos para cada genótipo foi: Purple Ruffles $0,6 \%$ de rendimento; Dark Opal 0,2\%; Local Hortaliça 0,7\%; Rubi $0,4 \%$ e Citral $0,5 \%$. Os resultados evidenciam que o genótipo Local Hortaliça obteve a maior porcentagem de rendimento de óleo essencial nas condições de ensaio, podendo ser uma opção para obtenção de óleo de melhor qualidade e com melhor produtividade a partir das caraterísticas desejadas.

Palavras-chave: Ocimum basilicum, óleo essencial, manjericão, composição química. 


\section{DESCRIPTION, ESSENTIAL OIL COMPOSITION, YEILD OF BASIL GENOTYPES CULTIVATED IN DISTRITO FEDERAL}

\section{ABSTRACT}

The basil (Ocimum basilicum L.) is widely used in the popular medicine and its essential oil has great value of market, also has sufficiently interest in its use for ornamental purposes beyond diverse morphologic characteristics as the leaf conformation, and the colour of the bloom and leaves, the color also became an object of study due some varieties to possess the purple coloration. In the present study, the chemical composition of the essential oil was evaluated, of four genotypes of purple basils and one of green basil. The plants had been cultivated in greenhouse. The extrations had been carried through by hydrodestilation in modified and the analyses had been carried through in Shimadzu chromatograph, GC 17A. The objective of the study was to verify the income and the qualitative and quantitative chemical composition of the essential oil of the five genotypes of Ocimum basilicum, four purple accesses and one green, cultivated in Brasília, for identifies them and esteem its potential in the ornamental, nourishing and cosmetic market. The majority composites and the too much composites in bigger amount found in the essential oil of the access Purple Ruffles had been metil-chavicol (55.15\%) fenchona (23.36\%), bergamoteno alpha trans $(6.27 \%)$, 1,8-cineol (3.3\%) and alpha cadinhol (3\%). For the access Dark Opal: linalol (52.8\%), bergamoteno alpha trans (12.5\%), 1,8-cineol (8.8\%), alpha cadinol (3.4\%) and eugenol $(2.85 \%)$, whereas for the access Local Hortaliça it was gotten: linalol $(35.9 \%)$, eugenol (28.9\%), 1,8-cineol (8.1\%) and alpha cadinol (6.9\%). For the genotype Ruby: linalol (54.5\%), eugenol (6.7\%), germacreno-D (5\%), alpha cadinol (5\%), 1,8-cineol (3.5\%). In the Citral genotype Geranial was gotten (40.7\%), neral (32\%), nerol (4.3\%) and linalol (4\%). The referring results to the income of gotten essential oils for each genotype were: Purple Ruffles $0.6 \%$ of income; Dark Opal 0.2\%; Loc Holrtaliça $0.7 \%$; Ruby $0.4 \%$ and Citral $0.5 \%$. The results evidence that the genotype Local Hortaliça got the biggest percentage of oil essential income in the assay conditions, being able to be an option for oil attainment of better quality and with better productivity from the desired carateristics.

Key words: Ocimum basilicum, essential oil, basil, chemical composition. 


\section{INTRODUÇÃO}

A interferência do homem com a seleção, cultivo e hibridação no gênero Ocimum, além das várias espécies que o compõem e a grande variação morfológica entre elas, contribuem para que algumas características sejam difícil de serem esclarecidas. Um sistema de descritores padrão com base nos óleos voláteis foi proposto, porém, os fatores ambientais são grandes influenciadores na composição destes óleos, o que limita a utilização dos descritores (JANNUZZI, 2013).

Numa determinada espécie, a concentração de cada um dos constituintes do seu óleo volátil pode variar durante o desenvolvimento do vegetal (RAMOS, 2004).

Apesar das diferenças quimiotipicas encontradas durante as fases de crescimento, observa-se que as diferenças morfológicas são acentuadas, tornando mais fácil ao consumidor associar alguma característica mais incomum. Dessa forma, - estudo de morfologia permanece sendo importante para o mercado e desenvolvimento de pesquisas com Ocimum. $O$ fato de grande quantidade de acessos não florescer, ajuda a manter a identidade do genótipo em função de se multiplicarem vegetativamente (JANNUZZI, 2013).

Óleo essencial de Ocimum basilicum L., com alta concentração de linalol, é valorizado no mercado internacional e amplamente usado na indústria de condimentos e cosméticos. Para garantir excelente qualidade e rendimento de óleo essencial é crucial a determinação do efeito dos fatores ambientais e de processamento na sua composição. CARVALHO FILHO et al. (2006) avaliaram o efeito do horário de colheita, da temperatura e do tempo de secagem no teor e na composição química do óleo essencial de $O$. basilicum. Colheitas foram realizadas aos 40 e 93 dias após transplante das mudas. Colheitas realizadas às $8: 00 \mathrm{~h}$ e $12: 00 \mathrm{~h}$ proporcionaram os maiores rendimentos de óleo essencial. Ao quinto dia de secagem o teor de linalol no óleo essencial subiu de $45,18 \%$ para $86,80 \%$. O. basilicum deve ser colhido pela manhã e a biomassa deve ser seca a $40 \stackrel{\circ}{\circ}$ por um período de cinco dias para obter óleo essencial rico em linalol.

O genótipo tem marcada influência sobre a composição do óleo essencial bem como o manejo agricultural, época do corte, idade da planta e densidade de plantio, além de fatores ambientais: temperatura, umidade relativa, irradiação e fotoperíodo (BRUNETON, 1991). 
Observa-se considerável variação na composição química dos óleos essenciais, dependendo dos quimiotipos que são determinados geneticamente e que embora correspondam a vegetais botanicamente idênticos, encontram-se diferenças químicas entre eles. A ocorrência de quimiotipos é comum em plantas ricas em óleos essenciais (RAMOS, 2004).

Os óleos voláteis apresentam um índice de retenção e são opticamente ativos, sendo que estas propriedades são utilizadas na sua identificação e no controle de qualidade. Na mistura, esses compostos se apresentam em diferentes concentrações, sendo que um deles é o composto majoritário, acompanhado de outros que estão em menores concentrações e mais alguns em quantidades ínfimas (RAMOS, 2004). A qualidade comercial do óleo essencial depende das proporções relativas de seus diferentes constituintes (BRUNETON, 1991). 


\section{ENSAIO 1 - COMPOSIÇÃO DO ÓLEO ESSENCIAL DE CINCO ACESSOS DE MANJERICÕES EM BRASÍLIA}

Foram cultivadas, em casa de vegetação na Estação Experimental de Biologia da UnB, mudas de 5 acessos de Ocimum basilicum (Tabela 5). As condições de casa de vegetação tipo glasshouse foram: $40 \%$ de sombra medida por fotômetro Asahi Pentax SP-500, temperatura média do ambiente durante ao ensaio registrando média das mínimas em $17,5^{\circ}$.C e das máximas em 36,5․C, medida por termômetro convencional de máxima e mínima.

Tabela 5. Acessos de Ocimum basilicum pesquisados, nome comercial e procedência.

\begin{tabular}{ll}
\hline Acesso & Origem/Firma \\
\hline Dark Opal & Top Seed $\left({ }^{1}\right)$ \\
Local hortaliça & Sítio Corujinha - DF $\left(^{2}\right)$ \\
Local ornamental & Holambra- EEB $\left(^{2}\right)$ \\
Purple Rufles & Holambra - EEB $\left({ }^{2}\right)$ \\
Rubi & Feltrin $\left({ }^{1}\right)$ \\
Citral & UnB $\left(^{(3)}\right.$ \\
\hline (1) sementes adquiridas no comércio formal de sementes \\
${ }^{(2)}$ sementes obtidas a partir de mudas adquiridas no comércio formal \\
$\left({ }^{3}\right)$ produção local (Estação Experimental-UnB)
\end{tabular}

Providenciou-se o semeio em caixas sementeiras. Quarenta dias após a germinação, as mudas foram transplantadas para vasos de $3 \mathrm{~L}$ de capacidade preenchidos com a Mistura EEB, para o acompanhamento do seu desenvolvimento. A Mistura EEB constou de latossolo vermelho de cerrado mais areia, vermiculita e composto orgânico respectivamente na proporção 3:1:1:1, mais a formulação 4-14-8, na dose de $100 \mathrm{~g}$ para cada $40 \mathrm{~L}$ da mistura. A Mistura EEB em análise por amostragem apresentou a seguinte composição média: matéria orgânica, 8,2\%; nitrogênio, 0,52\%; fósforo total $0,21 \%$; potássio $0,46 \%$; carbono orgânico $4,8 \%$; relação $\mathrm{C} / \mathrm{N}, 9,2 ; \mathrm{pH}=6,2$.

Ao atingirem a fase de floração as plantas foram caracterizadas (descritas) de acordo com a morfologia externa: formato da copa, largura da copa, diâmetro do caule a $10 \mathrm{~cm}$ de altura, altura da planta, morfologia da folha (margem, ápice, base, 
comprimento (C), largura (L), relação C:L. e crisposidade), tamanho da inflorescência, tamanho do entrenó da inflorescência e número de verticilos da inflorescência e coloração pétala/sépala e tamanho da flor. Em seguida, as plantas foram analisadas quanto à composição do óleo essencial.

O óleo essencial das folhas foi extraído pelo método de hidrodestilação em aparelho tipo Clevenger modificado (SANTOS et al., 2004), em balão, com capacidade de 2,0 L por 1 hora e 30 minutos (CASTRO, 2001; STASHENKO et al., 2003). Após a destilação, o óleo essencial foi pesado em balança de precisão e conservado ao abrigo da luz e refrigerado a $5^{\circ} \mathrm{C}$ até a análise cromatográfica.

O teor (g) ou conteúdo de óleo essencial existente nos acessos foi definido pela razão entre a massa de folhas secas inseridas no balão de destilação e a massa (g) de óleo essencial obtido. Em função da variação quantitativa de folhas secas inseridas no balão, o teor foi corrigido para de $100 \mathrm{~g}$ de massa de folhas secas, onde podemos comparar as diversas amostras, conforme a fórmula a seguir:

Equação 1. Cálculo para rendimento de óleo essencial (\%).

Rendimento de Massa do óleo extraído $(\mathrm{g})$ $x 100$ óleo essencial (\%) Massa de folhas secas balão(g)

Análise cromatográfica

As análises cromatográficas foram realizadas na Embrapa Recursos Genéticos e Biotecnologia, Brasília/DF, onde foi utilizado o cromatógrafo Shimadzu GC 17A com auto-injetor AOC-20i, em coluna capitar HP-5 $(25 \mathrm{~m} \times 0,32 \mathrm{~mm} \times 0,25 \mu \mathrm{m})$ à temperatura do forno de $60^{\circ} \mathrm{C}$ a $240^{\circ} \mathrm{C}$ a $3^{\circ} \mathrm{C} / \mathrm{min}$, e o hidrogênio o gás carreador $(1,4 \mathrm{ml}$.min.). Foram injetados $0,05 \mu \mathrm{L}$ de óleo da diluição $(1,5 \mathrm{~mL}$ de diclorometano e 0,05 de óleo essencial) no modo split (1:100; injetor a $\left.250^{\circ} \mathrm{C}\right)$.

Índices de retenção lineares foram calculados a partir dos tempos de retenção dos componentes do óleo e aqueles de uma mistura de $n$-alcanos $\left(\mathrm{C}_{7}-\mathrm{C}_{26}\right)$, injetada na mesma coluna e condições cromatográficas descritas para a análise dos óleos (VAN DEN DOOL e KRATZ, 1963). Padrões de interesse foram utilizados para identificação dos compostos majoritários. A análise estatística determinou o desvio padrão dos dados. 


\section{RESULTADOS E DISCUSSÃO}

Foram obtidos os seguintes resultados a partir do ensaio de caracterização morfológica dos dois genótipos ainda não descritos pela literatura que foram nomeados "Local Hortaliça" e "Local Ornamental" (Tabela 5).

LOCAL HORTALIÇA: plantas com $70 \mathrm{~cm}$ de altura. Folhas verdes assim como os ramos. Margem serrada, com ápice agudo e base obtusa, pouca crisposidade. Flores brancas e inflorescência roxa, corola clara, talo e cálices roxos. Rendimento em óleo essencial $0,73 \%$. Componentes majoritários do óleo essencial (OE), linalol $(35,9 \%)$, eugenol $(28,9 \%)$ e 1,8 -cineol (8\%), epi $\alpha$-cadinol $(4,9 \%)$ e germacreno-D $(2,7 \%)$.

LOCAL ORNAMENTAL: plantas com $64 \mathrm{~cm}$ de altura. Folhas verdes com manchas roxas ou quase completamente roxas. Margem serrada, com ápice agudo e base obtusa, sem crisposidade. Flores roxas e brancas e inflorescência roxas ou verdes, corola roxa e estames amarelos claro. Rendimento em óleo essencial $0,85 \%$.

Tabela 6. Características morfológicas observadas em dois genótipos, Local Hortaliça e Local Ornamental, de Ocimum basilicum cultivados em Brasília (média de seis leituras).

\begin{tabular}{ccc}
\hline & Local Hortaliça & Local Ornamental \\
\hline & Limbo e Pecíolo & \\
\hline Formato do limbo & Ovado & Ovado \\
Comprimento $(\mathrm{C}) \mathrm{cm}$ & 3,91 & 5,78 \\
Largura $(\mathrm{L}) \mathrm{cm}$ & 2,78 & 3,1 \\
Pecíolo $(\mathrm{P}) \mathrm{cm}$ & 1,36 & 3,06 \\
Relação $\mathrm{P} / \mathrm{C}$ & 0,34 & 0,52 \\
Área $(\mathrm{CxL})$ & 10,87 & 17,92 \\
Afilamento $(\mathrm{C} / \mathrm{L})$ & 1,40 & 1,86 \\
Margem & Serrada & Serrada \\
Ápice & Agudo & Agudo \\
Base & Obtusa & Obtusa \\
\hline Cor & Inflorescência & \\
Arquitetura & Roxa & Roxa \\
Tamanho cm & Ereta & Ereta \\
Entrenó cm & 70 & 64 \\
Verticilos $(\mathbf{n})$ & 3 & 5 \\
Flor cm & 9 & 14 \\
Cálice cm & 1,2 & 1,4 \\
Pedúnculo cm & 0,5 & 0,4 \\
Fruto $\mathrm{cm}$ & 0,5 & 0,5 \\
Cor da corola & $0,2 \times 0,1$ & $0,2 \times 0,1$ \\
Cor dos estames & Branca & Roxa \\
\hline Cosím & Amarela & Amarela claro \\
\hline
\end{tabular}

Notas: cm (centímetros); N (número).

A tabela 6 apresenta algumas características morfológicas de dois genótipos avaliados, que ainda não possuíam descrições na literatura. 
O teor de óleo essencial nos genótipos de manjericão variou de 0,27 a 0,95\%. O genótipo Local Hortaliça apresentou o segundo maior rendimento de óleo, superior a 0,7\%, enquanto que o Citral obteve rendimento de 0,95\% (Tabela 7 ). De acordo com KERROLA et al. (1994), o teor de óleo essencial varia com a espécie, fatores ambientais, manejo, método de extração e o tipo de material: fresco ou seco. Em estudos de espécies do Brasil, VIEIRA E SIMON (2006) identificaram rendimento entre 0,3 a 3,6\%. BLANK et al. (2004), no entanto, identificaram em 53 genótipos de Ocimum basilicum no Nordeste, teores de óleo essencial variando de 0,19 a 2,5\%.

Tabela 7. Componentes majoritários no óleo essencial de cinco acessos de Ocimum basilicum cultivados em Brasília e o rendimento de óleo essencial de seis genótipos, expressos em porcentagem (\%).

\begin{tabular}{|c|c|c|c|c|c|c|c|c|}
\hline Acesso & Linalol & $\begin{array}{c}\text { Metil- } \\
\text { chavicol }\end{array}$ & Eugenol & Geranial & Neral & $\begin{array}{c}1,8- \\
\text { cineol }\end{array}$ & atb & $\begin{array}{c}\text { Rendimento de } \\
\text { óleo }\end{array}$ \\
\hline Citral & . & - & - & 40,7 & 31,9 & - & - & 0,73 \\
\hline Dark Opal & 52,8 & - & & & & 8,8 & 12,5 & 0,27 \\
\hline Local Hort. & 35,9 & 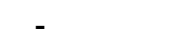 & 28,9 & & & 8,0 & & 0,73 \\
\hline P. Rufles & 23,4 & 55,2 & - & - & - & - & - & 0,50 \\
\hline Rubi & 54,6 & - & 6,7 & - & - & - & - & 0,40 \\
\hline Local Orn. (1) & - & - & - & - & - & - & - & 0,85 \\
\hline
\end{tabular}

Nota: Local Hort. $=$ Local Hortícola; Local Orn. $=$ Local Ornamental; $\alpha \mathrm{TB}=\alpha$ trans bergamoteno; $\mathrm{P}$. Rufles= Purple Rufles. $\left({ }^{1}\right)$ Não foi realizada a identificação de componentes majoritários.

A Tabela 7 apresenta os componentes majoritários no óleo essencial de cinco acessos de Ocimum basilicum cultivados em Brasília e possibilita a nomeação dos quimiotipos, com base nos componentes cuja percentagem no óleo essencial ultrapassem $11 \%$. O acesso Citral assim denominado previamente em virtude do forte odor cítrico de suas folhas é do quimiotipo citral (neral + geranial). O acesso Dark Opal é do quimiotipo linalol - $\alpha$ trans bergamoteno. O acesso Local Hortaliça é do quimiotipo linalol-eugenol. O acesso Purple Rufles é do quimiotipo metil chavicol-linalol e o acesso Rubi é do quimiotipo linalol.

Em O. basilicum, conforme pesquisa realizada em Brasília, os componentes mais comuns no óleo essencial são: 1,8-cineol; linalol, terpinen-4-ol; metilchavicol; eugenol e a-cadinol (SANSON, 2009). As espécies mais conhecidas do gênero Ocimum apresentam como constituintes majoritários em seu óleo essencial o metil chavicol, eugenol, linalol, 1,8-cineol (BARITAUX et al., 1992), cinamato de metila (PEREZ et al., 1995), geraniol (CHARLES e SIMON, 1990) e timol (NTEZURUBANZA et al., 1984).

Foram identificados de 55 componentes químicos no total. 23 a 32 componentes químicos que representam $91,5 \%$ a $99,1 \%$ do óleo essencial em cada um dos cinco 
genótipos avaliados. Os compostos não identificados variaram de 0,9\% a 8,5\%, quantidade relativamente maior quando comparado a OZCAN E CHALCHAT (2002), na Turquia, analisaram a parte aérea de $O$. basilicum e $O$. minimum, identificando 49 componentes em $O$. basilicum e $41 \mathrm{em} O$. minimum, os quais corresponderam a $88,1 \%$ e $74,4 \%$ do óleo essencial, respectivamente.

Tabela 8. Porcentagens de componentes no óleo essencial de cinco genótipos de Ocimum basilicum cultivados em Brasília. Tempo: segundos; IK (Índice de Retenção de Kovats). Adams, 1995.

\begin{tabular}{|c|c|c|c|c|c|c|c|c|}
\hline \multirow{2}{*}{ NOME SUBSTANCIA } & \multirow{2}{*}{ TEMPO } & \multirow{2}{*}{ IK } & \multirow{2}{*}{ IKcalc } & \multirow{2}{*}{$\begin{array}{l}\text { PURPLE } \\
\text { RUFFLES } \\
\%\end{array}$} & \multirow{2}{*}{$\begin{array}{c}\text { DARK } \\
\text { OPAL } \\
\%\end{array}$} & \multirow{2}{*}{$\begin{array}{c}\begin{array}{c}\text { Local } \\
\text { Hortaliça }\end{array} \\
\%\end{array}$} & \multirow{2}{*}{$\begin{array}{c}\text { RUBI } \\
\%\end{array}$} & \multirow{2}{*}{$\begin{array}{c}\text { CITRAL } \\
\%\end{array}$} \\
\hline & & & & & & & & \\
\hline a pineno & 6.487 & 939 & 938 & & 0,2 & & & \\
\hline Sabineno & 6.081 & 975 & 976 & & 0,3 & 0,2 & & \\
\hline$\beta$ pineno & 6.175 & 979 & 979 & 0,2 & 0,7 & 0,4 & 0,2 & \\
\hline 2,1 6-metil-5 hepteno & 6.412 & 986 & 988 & 0,2 & & & & 0,2 \\
\hline Mirceno & 6.535 & 990 & 991 & 0,3 & 0,7 & 0,3 & 0,3 & \\
\hline Limoneno & 7.732 & 1029 & 1031 & & 0,3 & 0,2 & 0,2 & \\
\hline 1,8 cineol & 7.814 & 1031 & 1034 & 3,3 & 8,8 & 8 & 3,5 & \\
\hline trans $\beta$ ocimeno & 8.391 & 1050 & 1051 & & & & & 0,2 \\
\hline octanol N & 9.161 & 1068 & 1072 & & & & & 0,2 \\
\hline Cis hidrato de sabineno & 9.060 & 1070 & 1069 & 0,1 & 0,4 & & 0,2 & \\
\hline Fenchona & 10.370 & 1087 & 1087 & 0,5 & 0,2 & & 0,4 & 0,1 \\
\hline Linalol & 10.423 & 1098 & 1104 & 23,4 & 52,8 & 35,9 & 54,6 & 4 \\
\hline miroxido D & 11.973 & 1135 & 1135 & & & & & 0,6 \\
\hline Canfora & 12.044 & 1146 & 1147 & & & 0,2 & 0,9 & \\
\hline$\delta$ terpineol & 12.970 & 1166 & 1169 & & 0,3 & 0,3 & 0,2 & \\
\hline$\alpha$ terpineol & 13.992 & 1189 & 1189 & 0,2 & 1,6 & 1,5 & 1,3 & 0,2 \\
\hline metil chavicol & 14.494 & 1196 & 1196 & 55,2 & & & & \\
\hline acetato de octanol & 14.934 & 1213 & 1213 & & 0,4 & & & \\
\hline Nerol & 15.667 & 1229 & 1231 & & & & & 4,3 \\
\hline Neral & 16.323 & 1238 & 1238 & & & & & 31,9 \\
\hline Geraniol & 16.803 & 1252 & 1252 & & & & 1,6 & 0,8 \\
\hline Geranial & 17.664 & 1267 & 1267 & & & & & 40,7 \\
\hline acetato de bornila & 18.115 & 1287 & 1286 & & & 0,3 & 0,4 & \\
\hline Eugenol & 21.363 & 1359 & 1362 & & 2,8 & 28,9 & 6,7 & \\
\hline acetato de nerila & 21.606 & 1361 & 1367 & & & & & 0,4 \\
\hline$\alpha$ copaeno & 22.030 & 1377 & 1376 & & & & & 0,2 \\
\hline hexanoato de hexenil & 22.441 & 1380 & 1385 & & & & & 0,2 \\
\hline acetato de geranila & 22.558 & 1381 & 1388 & & & & 0,9 & 0,3 \\
\hline$\beta$ elemeno & 22.734 & 1390 & 1391 & 0,5 & 1,1 & 1,1 & 1,7 & \\
\hline metil eugenol & 23.310 & 1403 & 1404 & 0,2 & 0,3 & 1,1 & 0,2 & \\
\hline a bergamoteno & 23.745 & 1412 & 1415 & & 0,1 & & & \\
\hline$\beta$ cariofileno & 23.865 & 1419 & 1419 & 0,6 & 0,6 & 1,2 & 1,5 & 2,8 \\
\hline$\alpha$ trans bergamoteno & 24.631 & 1434 & 1435 & 6,3 & 12,5 & 0,3 & 0,7 & 1 \\
\hline
\end{tabular}




\begin{tabular}{|c|c|c|c|c|c|c|c|c|}
\hline a guaieno & 24.760 & 1439 & 1440 & & 0,2 & 0,6 & 0,9 & \\
\hline a humuleno & 25.313 & 1454 & 1455 & 0,3 & 0,8 & 0,6 & 1,1 & 0,5 \\
\hline$\beta$ farneseno & 25.537 & 1456 & 1459 & & 0,3 & 0,3 & 0,4 & \\
\hline germacreno D & 26.480 & 1485 & 1485 & 0,9 & 2,3 & 2,7 & 5,1 & 1,8 \\
\hline Biciclogermacreno & 27.531 & 1500 & 1505 & 0,8 & 1,1 & 1,2 & 2,1 & \\
\hline$\beta$ bisaboleno & 27.684 & 1506 & 1509 & & & & & 0,2 \\
\hline a bulseneno & 27.133 & 1509 & 1510 & 0,5 & & 1,8 & & \\
\hline Y cadineno & 27.881 & 1514 & 1514 & 0,9 & 1,2 & 2,7 & 1,9 & \\
\hline$\beta$ sesquifilandreno & 28.297 & 1522 & 1525 & 0,3 & 1,2 & & & \\
\hline trans nerolidol & 29.912 & 1563 & 1565 & 0,1 & & 0,5 & 0,3 & \\
\hline Viridiflorol & 30.403 & 1573 & 1577 & & & & 0,2 & \\
\hline Spatulenol & 30.408 & 1578 & 1577 & 0,2 & & 0,6 & 0,5 & \\
\hline oxido de cariofileno & 34.508 & 1583 & 1582 & & & & & 0,7 \\
\hline 1,10-di-epi cubenol & 31.907 & 1619 & 1619 & 0,4 & 0,5 & 0,9 & 0,7 & \\
\hline epi $\alpha$ cadinol & 32.936 & 1640 & 1640 & 2,9 & 3,4 & 6,9 & 4,9 & \\
\hline$\beta$ eudesmol & 33.271 & 1651 & 1650 & & 0,4 & & 0,1 & \\
\hline$\alpha$ cadinol & 33.258 & 1654 & 1651 & 0,5 & & 0,4 & 1,5 & \\
\hline a bisabolol & 38,628 & 1685 & 1748 & & & & & 0,2 \\
\hline TOTAL \% & & & & 98,8 & 95,5 & 99,1 & 95,2 & 91,5 \\
\hline NÃO IDENTIFICADOS \% & & & & 1,2 & 4,5 & 0,9 & 4,8 & 8,5 \\
\hline
\end{tabular}

O perfil químico dos compostos majoritários e os demais representativos do óleo essencial dos genótipos de manjericão é apresentado na tabela 8. SANSON (2009) em Brasília encontrou que o acesso Local Hortaliça, denominado à época de Colunar Roxo era do quimiotipo linalol-1,8 cineol, respectivamente 53,57\% e 12,87\%. CANINI (2012) analisou o mesmo manjericão em duas estações, águas e seca, em Brasília, e encontrou que a sazonalidade não modificou o quimiotipo tendo encontrado linalol $61,87 \%$ e 1,8 cineol $11,76 \%$ nas águas e linalol $57,76 \%$ e 1,8 cineol $16,04 \%$ na seca. No período chuvoso a autora encontrou ainda $9,165 \%$ de eugenol. No presente ensaio encontrou-se $28,9 \%$ de eugenol no mesmo acesso. Trabalhos anteriores indicam que o eugenol é bastante influenciado pelas condições ambientais (VIANNA, 2009).

O linalol foi o composto predominante no óleo essencial dos genótipos avaliados, variando de $54,56 \%$ a $23,4 \%$. Os genótipos Rubi (54,56\%), Dark Opal (52,8\%), Local hortaliça $(35,88 \%)$ e Purple Ruffles $(23,4 \%)$ apresentaram os maiores teores de linalol. O genótipo Citral apresentou 40,7\% de geranial, $31 \%$ de neral e o menor teor de linalol (4\%). Segundo LORENZI E MATTOS (2002), o linalol, 1,8-cineol e eugenol são os principais compostos do manjericão. O que se pode observar no trabalho de BLANK et al. (2007), com a presença de $78,1 \%$ de linalol em sua composição. O linalol é referido como um componente predominante nos óleos essenciais em várias espécies de 
plantas aromáticas (CROTEAU, et al., 2000). É um importante componente químico aromático, largamente usado como fixador de fragrâncias na indústria cosmética mundial (GARLET, 2007), sendo encontrado em aproximadamente $80 \%$ dos compostos processados nas indústrias de cosméticos.

Quanto ao 1,8-cineol, é considerado um composto secundário do óleo essencial com concentrações variando de 2 a 16\% (HILTUNEN; HOLM, 1999). (CANINI, 2012) encontrou comportamentos opostos em relação à percentagem relativa dos compostos linalol e 1,8-cineol que puderam ser explicados pela sua rota de biossíntese, pois o 1,8-cineol, assim como o linalol, é um terpenóide, e são sintetizados pela mesma via metabólica, a do ácido mevalônico. Assim, nota-se que o aumento de um composto (linalol ou 1,8-cineol) acarreta na diminuição do outro pela competição nas rotas biossintéticas, o que não ocorreu no presente experimento, tendo em vista que nos genótipos que obtiveram a maior concentração de 1,8-cineol obtiveram grandes concentrações de linalol, assim como o genótipo que obteve menor concentração de 1,8-cineol também obteve a segunda maior concentração de linalol.

Nos genótipos avaliados, a concentração de 1,8-cineol foi de 3,3\% a 8,8\% e inexistente em alguns. Das cinco cultivares avaliadas, as duas que possuem a maior concentração de 1,8-cineol são "Local hortaliça" com 8,8\% e "Dark Opal" com pouco mais de $8 \%$. Ao ser emitido pelas flores serve como atrativo para polinizadores, incluindo abelhas, mariposas e morcegos (CROTEAU, et al., 2000). Possui ainda diversas aplicações terapêuticas, é usado no tratamento de reumatismo, tosse e asma brônquica. Possui efeito germicida útil na pediculose, além de atividade relaxante da musculatura lisa do intestino e das vias respiratórias (SANTOS, et al., 2005). Os níveis de 1,8 cineol dentro da planta aumentam com o aumento da intensidade da luz (OZEL E OZGUVEN, 2002).

O metil chavicol, também conhecido por estragol, é majoritário em $O$. basilicum, originário do Egito, llhas Reunion e Comoro (HILTUNEN; HOLM, 1999). O composto é utilizado na perfumaria, para aromatizar alimentos, além de matéria prima na fabricação sintética de anetol (anis), mas que pode ser encontrado como produto natural da ervadoce (Pimpinella anisum) e ao funcho (Foeniculum vulgare). Também é utilizado na Índia e China como produto para aromaterapia. Essa substância, segundo GROSSMAN (2005) não é indicada para uso medicinal. O composto metil chavicol também é usado na preparação de fragrâncias (SILVA, 2009). No Brasil, OLIVEIRA et al. (2013), 
identificaram em folhas secas e frescas os valores de linalol $(29,50 ; 32,26 \%)$ e metil chavicol $(36,81 ; 41,62 \%)$.

No presente estudo, o metil-chavicol foi identificado no genótipo Purple Ruffles na concentração de $55,15 \%$, valor este próximo aos que foram observados pelo estudo de OLIVEIRA et al. (2013). Número bem próximo para o linalol, respectivamente $(54,56 \%)$ e $(52,8 \%)$ e superior ao identificado por Simon et al. (1999) para a cultivar 'Lettuce leaf' para o teor de metil-chavicol de $29 \%$ e próximo ao valor identificado para o linalol (60\%).

MORALES et al. (1998) instalaram ensaio em casa de vegetação com 41 linhas $\mathrm{S}_{2}$ de Ocimum basilicum, (15 roxos, 8 marrons e 18 verdes) para identificar novos e promissores manjericões ornamentais. Variação suficiente foi encontrada dentro dos três genótipos na maioria dos crescimentos, produção e características do óleo essencial para sugerir que próximas seleções para as características procuradas seriam possíveis. Todas as linhas eram ricas em linalol, no entanto as linhas roxas de inflorescência compacta também continham uma substancial proporção de metil chavicol $(20-24 \%)$ e as marrons e brancas continham apenas pequenas quantidades de 1,8-cineol.

Observa-se na literatura relatos da presença de diversos compostos químicos em variedades de $O$. basilicum, predominando o linalol, eugenol, 1,8-cineol, metil chavicol, cinamato de metila, $\alpha$-bergamoteno entre outros (CAROVIC-STANKO et al., 2011; SILVA et al., 2003; VIEIRA E SIMON, 2000; KLIMÁNKOVÁ et al., 2007; JIROVETZ et al., 2003; VINÃ E MURILLO, 2003; LUZ et al., 2009; LUPE, 2007; SOARES et al., 2007; KÉITA et al., 2000). O material estudado apresenta assim características semelhantes àqueles que são comercializados e utilizados em diversas partes do mundo. 


\section{CONCLUSÕES}

1. Dos cinco genótipos testados, três genótipos de manjericão roxo apresentaram o linalol como principal componente.

2. Um dos genótipos de manjericão roxo apresentou o metil-chavicol como principal componente seguido pelo linalol.

3. O genótipo Local Hortaliça foi o único que apresentou quimiotipo linaloleugenol.

4. $\quad \mathrm{O}$ único genótipo verde testado apresentou quimiotipo Citral (Neral+geranial).

5. O genótipo Citral, apresentou o mais alto rendimento em óleo essencial. 


\section{REFERÊNCIAS BIBLIOGRÁFICAS}

BARITAUX, O.; RICHARD, T. J.; DERBESY, M. EFFECTS OF DRYING AND STORAGE OF HERBS AND SPICES ON THE ESSENTIAL OIL: PART L: BASIL, OCIMUM BASILICUM L. FLAVOUR AND FRAGANCE JOURNAL, [S.L.], V. 7, P. 267$271,1992$.

BLANK, A. F., CARVALHO FILHO, J. D., SANTOS NETO, A. D., ALVES, P. B., ARRIGONI-BLANK, M. D. F., SILVA-MANN, R., E MENDONÇA, M. D. C. . Caracterização morfológica e agronômica de acessos de manjericão e alfavaca. Horticultura Brasileira, 22(1), 113-116. 2004.

BLANK, A.F.; SOUZA, E.M.; PAULA, J.W.A.; ALVES, P.B. Comportamento fenotípico e genotípico de populações de manjericão. Horticultura Brasileira 28: 305-310. 2010.

BRUNETON, J. Elementos de Fitoquimica y de Farmacognosia. Zaragoza/ESP: Editorial Acribia, 1991. 594 p.

Carovic-Stanko, K.; Šalinović, A.; Grdiša, M.; Liber, Z.; Kolak, I.; e Satovic, Z. Efficiency of morphological trait descriptors in discrimination of Ocimum basilicum $\mathrm{L}$. accessions. Plant Biosystems-An International Journal Dealing with all Aspects of Plant Biology, 145(2), 298-305. 2011.

CANINI, G. B. Caracterização anatômica e composição química do óleo essencial de manjericão (Ocimum spp.). Brasília: Faculdade de Agronomia e Medicina Veterinária, Universidade de Brasília, 2012, 111 fls. Dissertação de Mestrado.

CARVALHO FILHO, J. L. S., BLANK, A. F., ALVES, P. B., EHLERT, P. A., MELO, A. S., CAVALCANTI, S. C. E SILVA-MANN, R. (2006). Influence of the harvesting time, temperature and drying period on basil (Ocimum basilicum L.) essential oil. Revista Brasileira de Farmacognosia, 16(1), 24-30.

Castro, H. G., Ferreira, F.A., Silva, D.J.H., Mosquim, P.R. Contribuição ao estudo de plantas medicinais: metabólitos secundários. Visconde do Rio Branco. Supremo. 2001. $104 \mathrm{p}$.

CROTEAU, R. et al. Natural products (secondary metabolites). In: BUCHANAM, B.B. et al. Biochemistry e molecular biology of plants. Rockville: Courier Companies, 2000, pg.1250-1318.

CHARLES, D.J.; SIMON, J.E. Comparison of extraction methods for the rapid determination of essential oil content and composition of basil (Ocimum spp.). Journal of the American Society for Horticultural Science, v.115, n.3, 1990, pg. 458-462.

GROSSMAM, L. (Coord.). Óleos essenciais: na culinária, cosmética e saúde. São Paulo: Optionline, 2005. $301 \mathrm{p}$.

HILTUNEN, R.; HOLM, Y. (Eds.). Basil. The genus Ocimum: Harwood Academic Publishers, Amsterdam, 1999. 182 pp 
JIROVETZ, L., BUCHBAUER, G., SHAFI, M. P., KANIAMPADY, M. M. Chemotaxonomical analysis of the essential oil aroma compounds of four different Ocimum species from southern India. Eur Food Res Technol (2003) 217:120-124.

KÉITA, S. M., VINCENT, C., SCHMIT, J. P., BÉLANGER, A. Essential oil composition of Ocimum basilicum L., O. gratissimum L. and O. suave L. in the Republic of Guinea. Flavour Frag. J. 15: 228-230, 2000.

KERROLA K; GALAMBOSI B; KALLIO H. 1994. Volatile components and odor intensity of four phenotypes of hyssop (Hyssopus officinalis L.). Journal of Agricultural and Food Chemistry 42: 776-781.

KLIMÁNKOVÁ E., HOLADOVÁ, K., HAJSLOVÁ, J., CAJKA, T., POUTSKA, J., KOUDELA, M. Aroma profiles of five basil (Ocimum basilicum L.) cultivars grown under conventional and organic conditions. Food Chemistry 107 (2008) 464-472.

LORENZI, H., MATOS, F.J.A. Plantas medicinais no Brasil: nativas e exóticas cultivadas. Ed:Nova Odessa, São Paulo. Instituto. Plantarum, 2002. 512p

LUPE, F. A. Estudo da composição química de óleos essenciais de plantas aromáticas da Amazônia. Dissertação de Mestrado. Universidade Estadual de Campinas, Instituto de Química, Campinas, SP, 2007.

LUZ, J. M. Q., MORAIS, T. P. S., BLANK, A. F., SODRÉ, A. C. B., OLIVEIRA, G. S. Teor, rendimento e composição química do óleo essencial de manjericão sob doses de cama de frango. Horticultura Brasileira 27: 349-353, 2009.

MORALES M.R., CHARLES D.J., SIMON J.E. New aromatic lemon basil germplasm. In: JANICK J, SIMON JE (eds) New crops. Wiley, New York, pp 632-635.1993

NTEZURUBANZA, L.; SHEFFER, J. J. C.; LOOMAN, A. Composition of essential oil of Ocimum kilimandscharicum grown in Ruanda. Planta Medica, [S.I.], v. 50, n. 5, p. 385388, 1984.

OLIVEIRA, R.A.; MOREIRA, I.S.; OLIVEIRA, F.F. Linalool and Methyl Chavicol present basil (Ocimum sp) cultivated in Brazil. Rev. Bras. Pl. Med., Campinas, v.15, n.2, p.309311, 2013.

OZCAN, M. e CHALCHAT, J. C. Essential oil composition of Ocimum basilicum and Ocimum minimum in Turkey. Czech Journal of Food Sciences., 20: 6, 223-228. 2002.

OZEL, A., RAM, D. e OZGUVEN, M. Effect of different planning times on essential oil components of different mint (Mentha spp.) variets. Tubitak: Turk Agric, 289-294 p. 2002.

PEREZ, A. M. J.; VELASCO, N. A.; DURU, M. E. Composition of the essential oils of Ocimum basilicum var. glabratum and Rosmarinus officinalis from Turkey. Journal of Essential Oil Research, [S.I.], v. 7, n. 1, p. 73-75, 1995. 
RAMOS, F. Extração de óleos essenciais. Disponível em: http://www.academia.edu/25004487/\%C3\%93LEOS ESSENCIAIS ESS\%C3\%8ANCI AS Acessado em fevereiro de 2017.

SANSON, A. D. Morfologia e produção de biomassa e perfil de aromáticos de seis acessos de manjericão coletados em feiras e supermarcados no Brasil. Brasília: Faculdade de Agronomia e Medicina Veterinária, Universidade de Brasília, 2009, 36 fls. Dissertação de Mestrado.

SANTOS, A.S.; ALVES, S.M.; FIGUEIRÊDO, F.J.C.; ROCHA NETO, O.G. Descrição de sistema e de métodos de extração de óleos essenciais e determinação de umidade de biomassa em laboratório. Embrapa Amazônia Oriental, Comunicado Técnico n.99, novembro, 2004.

SANTOS, A.S.; ALVES, S.M.; FIGUEIRÊDO, F.J.C.; ROCHA NETO, O.G. Descrição de sistema e de métodos de extração de óleos essenciais e determinação de umidade de biomassa em laboratório. Embrapa Amazônia Oriental, Comunicado Técnico n.99, novembro, 2004.

SILVA, A.K.S. Estudo das alterações eletrofisiológicas produzidas pelo estragol sobre os axônios do nervo ciático e os neurossomas do gânglio da raiz dorsal de ratos. Universidade Estadual do Ceará, Centro de Ciências da Saúde.Fortaleza, 2009. 69p. ; il. Dissertação de Mestrado Acadêmico em Ciências Fisiológicas.

SILVA, F., SANTOS, R. H. S., DINIZ, E. R., BAROBOSA, L. C. A., CASALI, V. W. D., DE LIMA, R. R. Teor e composição do óleo essencial de manjericão (Ocimum basilicum L.) em dois horários e duas épocas de colheita. Revista Brasileira de Plantas Medicinais, Botucatu, v.6, n.1, p.33-38, 2003.

SOARES, R. D., CHAVES, M. A., DA SILVA, A. A. L., SOUZA, B. S. Influência da temperatura e velocidade do ar na secagem de manjericão (Ocimum basilicum L.) com relação aos teores de óleos essenciais e de linalol.Ciênc. agrotec., Lavras, v. 31, n. 4, p. 1108-1113, jul./ago., 2007.

STASHENKO, E.E.; JARAMILHO, B.E.; MARTINEZ, J.R. Comparacion de La composicion química y de la actividad in vitro de los metabolitos secundários volátiles de plantas de la família Verbanceae. Rev. Acad. Colomb. Cienc. v.27, n.105, p.579597, 2003.

VAN DEN DOOL, H.; KRATZ, P. Dec. A generalization of the retention index system including linear temperature programmed gas-liquid partition chromatography. Journal of Chromatography, v. 11, p. 463-471, 1963.

VIANNA, J. S. Caracterização anatômica, morfológica e química de quimiotipos de Ocimum gratissimum Lineu. 2009. 78 f. Dissertação (Mestrado em Ciências Agrárias)Universidade de Brasília, Brasília, 2009.

VIEIRA, R. F., SIMON, J. E. Chemical characterization os Basil (Ocimum spp.) found in the markets and used in traditional medicine in Brasil. Economic Botany 54(2) p. 207216, 2000. 
VIEIRA, R.F.; SIMON, J.E. Chemical characterization of basil (Ocimum spp.) based on volatile oils. Flavour and Fragrance Journal. Volume 21, n. 2, p. 214-221 2006.

VINÃ, A., MURILLO, E. Essencial oil composition from twelve varieties of Basil (Ocimum spp) grown in Colombia. J. Braz. Chem. Soc. v.14 n.5, p. 744-749, 2003. 